\title{
Triassic Echinoids
}

\author{
PORTER M. KIER
}




\title{
SERIES PUBLICATIONS OF THE SMITHSONIAN INSTITUTION
}

Emphasis upon publication as a means of "diffusing knowledge" was expressed by the first Secretary of the Smithsonian. In his formal plan for the Institution, Joseph Henry outlined a program that included the following statement: "It is proposed to publish a series of reports, giving an account of the new discoveries in science, and of the changes made from year to year in all branches of knowledge." This theme of basic research has been adhered to through the years by thousands of titles issued in series publications under the Smithsonian imprint, commencing with Smithsonian Contributions to Knowledge in 1848 and continuing with the following active series:

\author{
Smithsonian Contributions to Anthropology \\ Smithsonian Contributions to Astrophysics \\ Smithsonian Contributions to Botany \\ Smithsonian Contributions to the Earth Sciences \\ Smithsonian Contributions to Paleobiology \\ Smithsonian Contributions to Zoology \\ Smithsonian Studies in Air and Space \\ Smithsonian Studies in History and Technology
}

In these series, the Institution publishes small papers and full-scale monographs that report the research and collections of its various museums and bureaux or of professional colleagues in the world cf science and scholarship. The publications are distributed by mailing lists to libraries, universities, and similar institutions throughout the world.

Papers or monographs submitted for series publication are received by the Smithsonian Institution Press, subject to its own review for format and style, only through departments of the various Smithsonian museums or bureaux, where the manuscripts are given substantive review. Press requirements for manuscript and art preparation are outlined on the inside back cover.

S. Dillon Ripley

Secretary

Smithsonian Institution 
SMITHSONIAN GONTRIBUTIONS TO PALEOBIOLOGY - NUMBER 30

\title{
Triassic Echinoids
}

\author{
Porter M. Kier
}

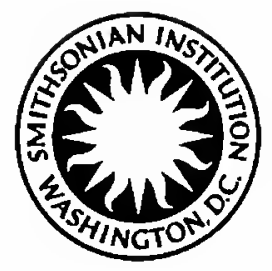

SMITHSONIAN INSTITUTION PRESS

City of Washington

1977 


\begin{abstract}
A B S T R A C T
Kier, Porter M. Triassic Echinoids. Smithsonian Contributions to Paleobiology, number 30,88 pages, 16 figures, 21 plates, 2 tables, 1977.-Although 142 species of Triassic echinoids have been reported, only 24 are based on sufficient material to permit reliable generic identification. These species are redescribed and illustrated. Twelve of them are from the St. Cassian Beds in the Italian Dolomites. A large collection of specimens from these beds is described, from which are erected two new species, Megaporocidaris mariana and Levicidaris zardinia, and five new genera: Zardinechinus, a miocidarid, Paurocidaris and Leurocidaris, cidarids, and the psychocidarids, Levicidaris and Megaporocidaris. A new pedinoid, Hemipedina hudsoni, is described from the Norian of Arabia. During the Early and Middle Triassic, only flexible miocidarids were present. Apparently all Mesozoic echinoids are descended from them. The first cidarids occur in the Late Triassic (Karnian) together with the first psychocidarids. The first certain pedinoid appears in the Norian. Finally at the close of the Triassic, in the Rhaetian, the first hemicidaroid appears.
\end{abstract}

OfFicial publication date is handstamped in a limited number of initial copies and is recorded in the Institution's annual report, Smithsonian Year. SERIES COVER DESIGN: The trilobite Phacops rana Green.

Library of Congress Cataloging in Publication Data

Kier, Porter M.

Triassic echinoids.

(Smithsonian contributions to paleobiology ; no. 30)

Bibliography: p.

Includes index.

Supt. of Docs. no.: SI 1.30:30

1. Sea-urchins, Fossil. 2. Paleontology-Triassic. I. Title. II. Series: Smithsonian Institution.

Smithsonian contributions to paleobiology; no. 30 .

QE701.S56 no. 30 [QE783.E2] $560^{\prime} .8$ s [563'.95] 76-24806 


\section{Contents}

Introduction

Paleozoic Antecedents

Early Triassic Echinoids

Middle Triassic Echinoids

Late Triassic Echinoids

Abbreviations for Institutions

$\ldots \ldots \ldots+\ldots r_{1}^{\text {Page }}$

Acknowledgments

Early Triassic: Scythian

Family Mrocidaridae Durham and Melville

Genus Miocidaris Döderlein

Miocidaris pakistanensis Linck

Genus Lenticidaris Kier

Lenticidaris utahensis Kier

Middle Triassic: Landinian .

Family Mrocidaridae Durham and Melville $\ldots \ldots .6$

Genus Serpianotiaris Jeannet . .... ....... 6

Serpianotiaris hescheleri (Jeannet) $\quad \ldots \ldots \ldots . \ldots$

Late Triassic: Karnian .... $\quad \ldots \ldots \ldots \ldots \ldots \ldots$

Species from the St. Cassian Beds . . . . . . . . . $\quad \ldots . \ldots$

Localities ..... . . . . . . . . . . .

Key to the Echinoids from the St. Cassian Beds $\ldots \ldots \ldots$.

Family MrocidaridaE Durham and Melville ........ 8

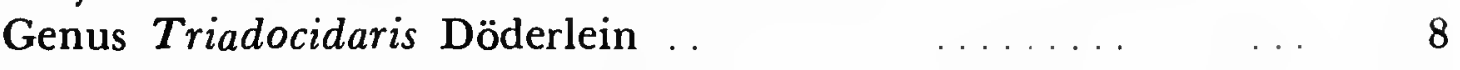

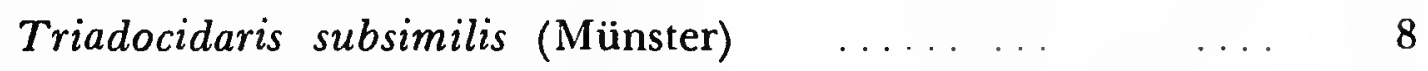

Triadocidaris suessii (Laube) .... $\quad \ldots \ldots \ldots \quad 10$

Triadocidaris venusta (Münster) $\quad \ldots \ldots \ldots . \quad \ldots \quad 11$

Triadocidaris giauensis (Zardini), new combination .. 12

Family Cidaridae Gray .. .............. 13

Genus Mikrocidaris Döderlein .... $\quad \ldots \ldots \ldots . \ldots$

Mikrocidaris pentagona (Münster) $\ldots \ldots \ldots . \ldots .13$

Genus Polycidaris Quenstedt ..... .......... 15

Polycidaris regularis (Münster) $\quad \ldots \ldots \ldots \quad \ldots \ldots \ldots \quad 15$

Zardinechinus, new genus $\ldots \ldots \ldots \ldots . \ldots \ldots .16$

Zardinechinus lancedelli (Zardini), new combination $\quad$ I6

Paurocidaris, new genus $\quad \ldots \ldots \ldots \ldots . \ldots \ldots 18$

Paurocidaris rinbianchi (Zardini), new combination $\ldots .18$

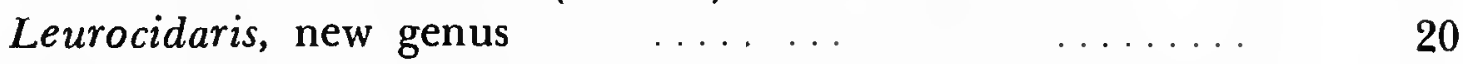

Leurocidaris montanaro (Zardini), new combination ...... 20

Family Psychocidaridae Ikeda ..... $\ldots \ldots \ldots . \ldots 21$

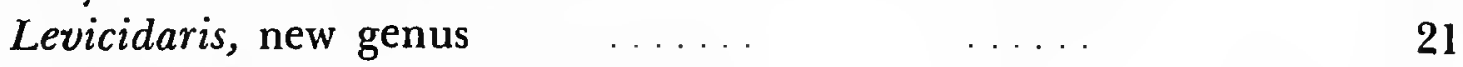

Levicidaris zardinia, new species $\quad \ldots \ldots \ldots \quad \ldots \quad 21$

Megaporocidaris, new genus .. $\quad \ldots \ldots . .22$

Megaporocidaris mariana, new species .... . . . . . 23

Family Tiarechinidae Gregory ... $\quad \ldots \quad \ldots \quad \ldots \ldots \ldots .24$

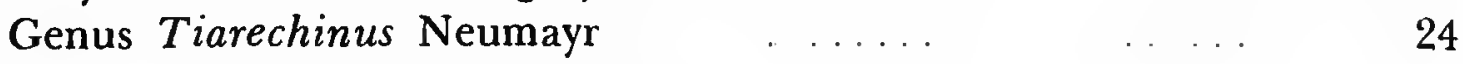


Tiarechinus princeps Neumayr

Genus Lysechinus Gregory ... _. . . . . .

Lysechinus incongruens Gregory _.....

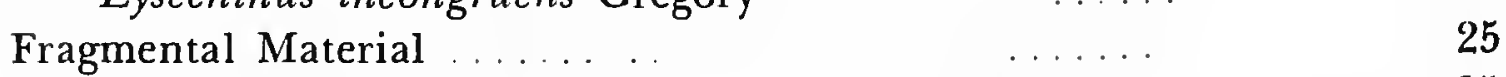

Triadocidaris species A _. . . . . $\quad \ldots .25$

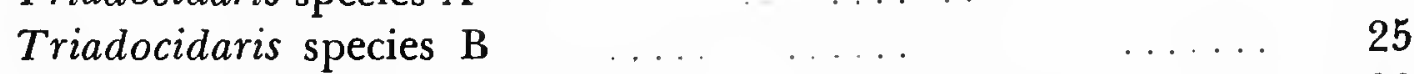

Species with Crenulate Tubercles _ . . $\ldots . . . \quad \ldots \quad 26$

Species $1 \quad \ldots \ldots \ldots \ldots \ldots 26$

Species $2 \quad \ldots \ldots \ldots \ldots 26$

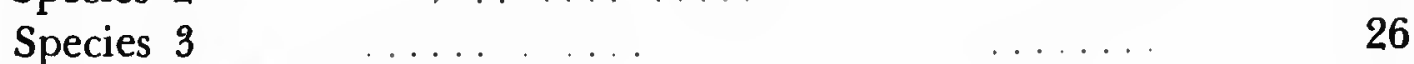

Mesodiadema? Fragments . . . . . . . . . . . . 27

Morphological Specimens ........ . . $\quad \ldots . . . \quad 27$

Species Not from the St. Cassian Beds . . . . . . . . . . . 28

Order Cidarolda Claus f... . . . . . . . . . 28

Family Miocidaridae Durham and Melville $\quad \ldots \quad \ldots \quad 28$

Genus Triadocidaris Döderlein $\ldots \ldots \ldots . . \ldots 28$

Triadocidaris persimilis Bather $\quad \ldots \ldots 28$

Triadocidaris immunita Bather $\quad \ldots . .28$

Genus Dicyclocidaris Fell .... . . . . 28

$\begin{array}{lll}\text { Dicyclocidaris denticulata Fell } & 28\end{array}$

Order Pedinoida Mortensen ..... . . . . $\quad 29$

Family Pedinidae Pomel ... . . . . . . . . 29

Genus Hemipedina Wright ... . . . . $\quad 29$

Hemipedina? incipiens Bather $\quad \ldots .29$

Late Triassic: Norian ...... . . . . . . . . 30

Order Pedinoida Mortensen $\ldots \ldots \ldots .30$

Family Pedinidae Pomel ........ .... 30

Genus Hemipedina Wright ... . . 30

Hemipedina hudsoni, new species $\quad \ldots \ldots \ldots . .30$

Late Triassic: Rhaetian . . . . . . . . . . . $\quad 32$

Order Cidaroida Claus ... . . . . $\quad \ldots . \ldots$.

Family Cidaridae Gray . . . . . 32

Genus Paracidaris Pomel _.... . . 32

Paracidaris toucasi (Cotteau) 32

Paracidaris jeanneti Lambert $\quad 32$

Order Pedinoida Mortensen . . . 33

Family Pedinidae Pomel ... . . . 33

Genus Diademopsis Desor $\quad 33$

Diademopsis? desori (Stoppani) 33

Order Hemicidaroida Beurlen $\ldots \ldots 33$

Family Pseudodiadematidae Pomel _ . . . 33

Genus Pseudodiadema Desor $\quad \ldots . .33$

Pseudodiadema silbinense Stefanini $\ldots \ldots \quad 33$

Genera Incertae Sedis _... . . . . 35

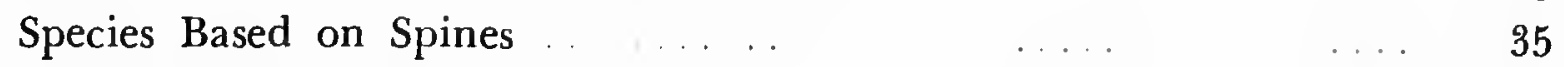

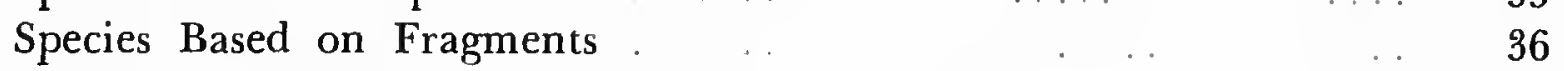

$\begin{array}{llllllll}\text { Corrected } & \text { Occurrences } & \ldots & \ldots & \ldots & \ldots & & \ldots\end{array}$

$\begin{array}{lllll}\text { Literature Cited } & \ldots & \ldots & \ldots & \end{array}$

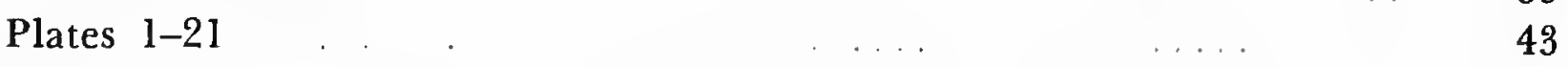

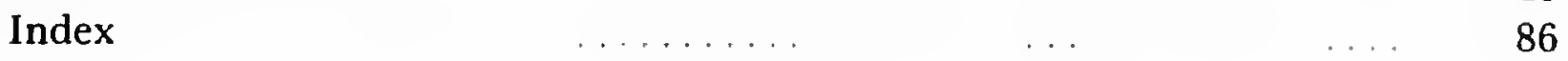




\title{
Triassic Echinoids
}

\author{
Porter M. Kier
}

\section{Introduction}

During the Early Mesozoic, echinoids underwent great diversification. Many new orders developed; and by the end of the era, all the orders of echinoids now living, except the clypeasteroids and neolampadoids, had developed. Generally, it has been believed that many of these new orders had their origin in the Triassic. For this reason I have undertaken a study in detail of the Triassic echinoid record.

Although over 142 species of echinoids have been reported from the Triassic, most of these species are based on spines or isolated plates. Only 24 are based on sufficient material to permit generic identification. Furthermore, many species attributed to the Triassic were actually collected in Jurassic rocks.

Most of the Triassic echinoids, particularly those from the famous St. Cassian Beds, have not been studied in over 100 years. Their original descriptions and illustrations are inadequate and in many instances erroneous. An effort has been made to study the type specimens of all species based on adequate material. Most of these specimens have been made available through the generosity of the curators of European museums. All identifiable species are redescribed and reillustrated here, except for a few in which the type specimens are lost.

The most important Triassic echinoid fauna is from the St. Cassian Beds in the Italian Dolomites.

Porter M. Kier, Department of Paleobiology, National Museum of Natural History, Smithsonian Institution, Washington, D. C. 20560.
An extraordinary collection of these echinoids has been made by Rinaldo Zardini of Cortina d'Ampezzo. He described and illustrated many of these specimens in 1973 and has very generously permitted me to study his material. The echinoids are beautifully preserved and represent 12 species, excluding those species based only on isolated spines and plates. Five of these species are referred to new genera. Two of these species are new and belong to the cidaroid family Psychocidaridae, a family not previously known to have occurred before the Late Jurassic.

Except for the St. Cassian Beds, the Triassic echinoid record is exceedingly poor. Only two identifiable species are known from the Early Triassic, only one from the Middle Triassic, and only nine from the Late Triassic (other than the St. Ciassian species).

Although the evidence (Figure 1) is scanty, it is nonetheless feasible to suggest the makeup of Triassic echinoid faunas. During the Early and most of the Middle Triassic, only one family of echinoid was living-the flexible miocidarids. This group originated in the Permian and is the only echinoid Eamily that survived into the Mesozoic. I believe that all Mesozoic echinoids are descended from them, and none of them are descended from other Paleozoic orders. In the early Late Triassic (Karnian), the first echinoids occur with rigid tests and imperforate tubercles. In the Late Karnian occurs the first noncidaroid (except for the aberrant plesiocidaroids). Although known only by fragments, its small tubercles and compound plates (the earliest 


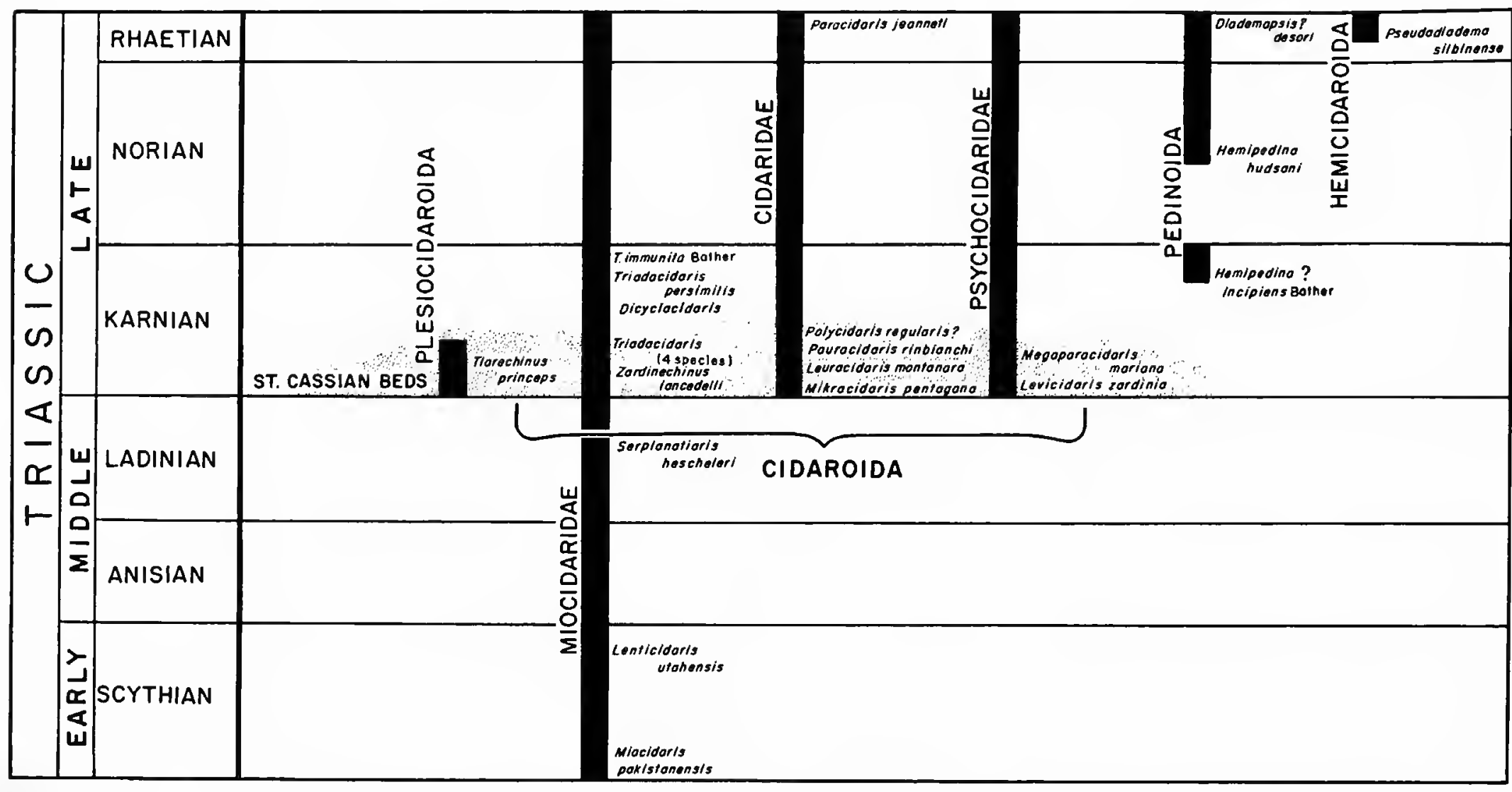

Figure 1.-Distribution of the Triassic echinoids based on sufficient material to permit generic determination.

known) suggest that it belonged to a pedinoid. The first undoubted pedinoid is found in the Norian and described here as a new species, Hemipedina hudsoni. Finally at the close of the Triassic, in the Rhaetian, the first hemicidaroid appears. In sum. mary only one order, Cidaroida, is present during the Early and Middle Triassic, but two more are present by the end of the Triassic, Pedinoida and Hemicidaroida.

During the Jurassic (Figure 2) three new orders are introduced in the Hettangian: the Diadematoida, the Phymosomatoida, and the Salenioida. The Pygasteroida originate during the Sinemurian; the Holectypoida, during the Pliensbachian; the Cassiduloida and Holasteroida during the Toarcian; and the Arbacioida and Orthopsida during the Bathonian. The Echinothurioida appear during the Oxfordian, and it is not until the Early Cretaceous (Neocomian) that the Spatangoida occur. In summary, the Triassic is not the time of greatest evolutionary change among the echinoids. Only three new orders originated then as contrasted to ten in the Jurassic.

\section{Paleozoic Antecedents}

Only two families of echinoids have been found in the Late Permian. One of them is the last of the flexible lepidestids, Pronechinus anatoliensis Kier, from the Late Permian of Turkey. The lepidestids have more than two columns of imbricating plates in both the interambulacra and ambulacra. Their isolated ambulacral plates are easily identified by their small size and hexagonal shape. None of these plates has ever been found in any post-Permian rocks. It is, therefore, a reasonable assumption that this group became extinct at the end of the Permian.

The other family of Late Permian echinoid is the miocidarids. These echinoids are descendants of the archeocidarids (Kier, 1968) and differ from the modern cidaroids primarily in having a test with imbricating plates. It is from this group that all the post-Paleozoic echinoids evolved. Although Mortensen (1935:50) and Philip (1965) suggested that some of the post-Paleozoic echinoids were derived from Paleozoic noncidarids, Durham and Melville (1957:250), and Kier $(1965: 451,1974: 4)$ can find no evidence to support this view and assert that all 


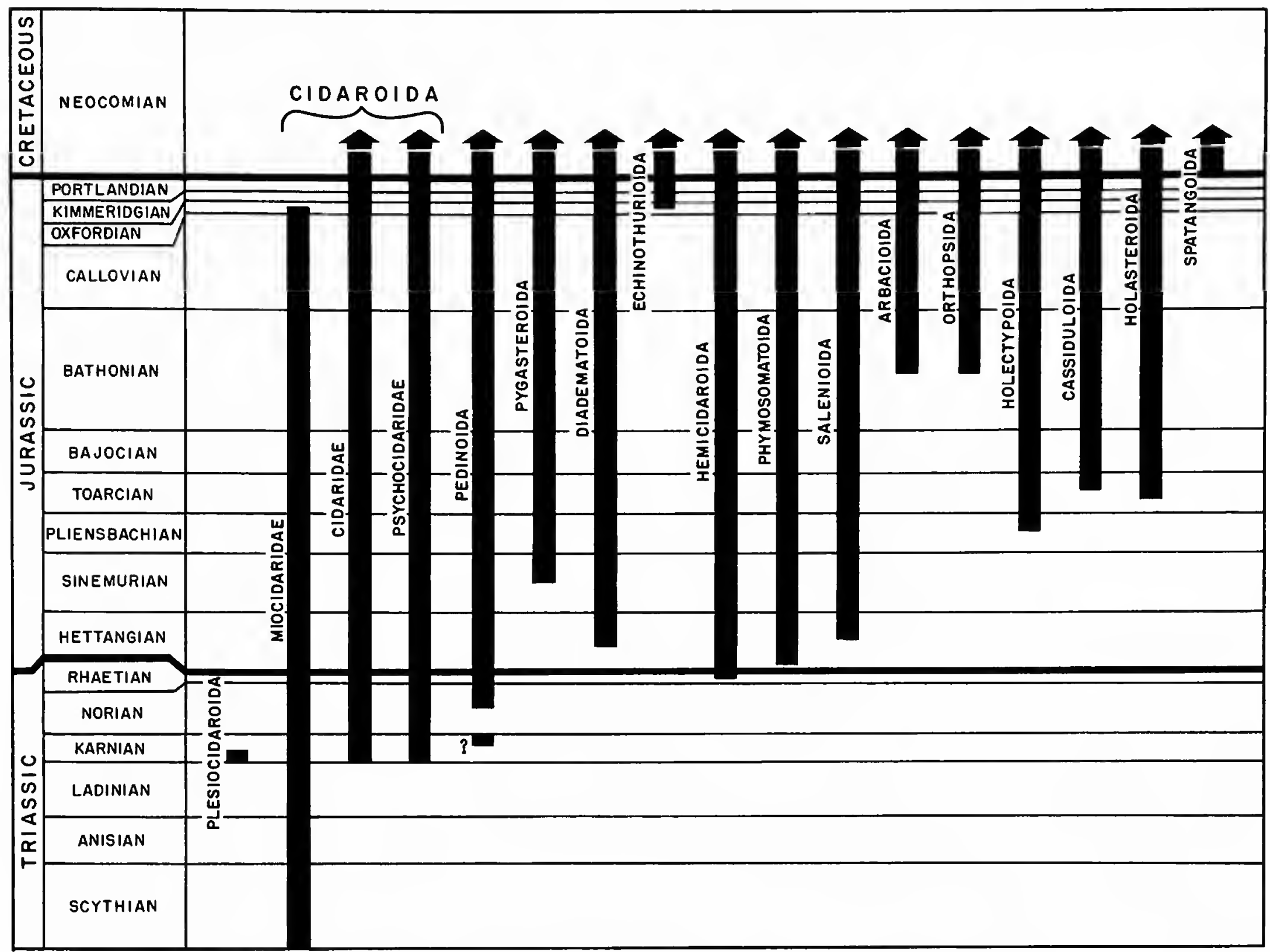

Figure 2.-Distribution of the echinoid orders during part of the Mesozoic.

post-Paleozoic echinoids are derived from cidaroids. This study of all the Triassic echinoids supports this position. All the Triassic echinoids studied appear to have been derived from a cidaroid ancestor.

\section{Early Triassic Echinoids}

Early Triassic echinoids are very similar to the miocidarids from the Late Permian. Only two Early Triassic species are known from adequate material-Miocidaris pakistanensis Linck and Lenticidaris utahensis Kier. Both these species belong to the family Miocidaridae. They have very flexible tests with the adapical interambulacral plates imbricating strongly dorsally over each other and the apical system, and with the interambulacral plates beveling over the ambulacral.

\section{Middle Triassic Echinoids}

Only one well-documented echinoid has been found in the Middle Triassic, Serpianotiaris hescheleri (Jeannet); it is, also, a miocidarid. Although in the Treatise (Durham, editor, 1966) it is placed in uncertain order and family, Jeannet in his original descriptions considered it to be a subgenus of Miocidaris. I believe it should be referred to the family Miocidaridae because of its flexible test, primary ambulacral plates, and perforate, crenulate tubercles. Although it lacks a prominent cortex 
layer on its spines, this layer is also lacking in Lenticidaris. However, its test is less flexible than in the two Early Triassic miocidarids, which is to be expected considering its younger age.

\section{Late Triassic Echinoids}

It is not until the Late Triassic that any kind of echinoids other than miocidarids are found. The most prolific echinoid fauna of the Triassic occurs in the St. Cassian Beds in the Italian Dolomite Mountains. They are considered by Silberling and Tozer (1968:14) to be lowermost Karnian, but some workers place them in the late Ladinian and early Karnian. Although specimens have been collected from these beds for over one hundred years, the most significant collections have been made lately by Rinaldo Zardini. Many of his specimens are illustrated here.

Five species of miocidarids have been found in these beds: Zardinechinus lancedelli (Zardini), Triadocidaris venusta (Münster), $T$. suessii (Laube), $T$. giauensis (Zardini), and $T$. subsimilis (Münster). Coinciding with these, the first nonmiocidarids appear. Until this time all the known Triassic echinoids had flexible tests, characteristic of the miocidarids, and perforate tubercles. Two families of the Cidaroida having rigid tests first appear in the Cidaridae and the Psychocidaridae. Within the Cidaridae three species have been found in the St. Cassian Beds: Paurocidaris rinbianchi (Zardini), Leurocidaris montanaro (Zardini), and Mikrocidaris pentagona (Münster). Two of these species are referred here to new genera.

A fifth cidarid, Polycidaris regularis (Münster), has been reported from these beds; but I suspect that its type specimen (and only known specimen) came from the Late Jurassic (Oxfordian), not from the St. Cassian Beds.

Two new species of the Psychocidaridae are present: Levicidaris zardinia and Megaporocidaris mariana. Both of these species have imperforate tubercles and nonconjugate pore-pairs. They are the earliest species possessing these characters. All Paleozoic and Early and Middle Triassic cidaroids had perforate tubercles. No imperforate tubercles are found in any miocidarids or archeocidarids.

Finally, in the St. Cassian Beds, appears the most unusual echinoid, Tiarechinus princeps Neumayr.
Among its peculiar characters is the presence of a single plate at the peristome in each interambulacrum and three plates in the row above. There are genital pores in only two of the genital plates, and no madreporite. Some workers have considered this species to be related to the Paleozoic echinoids because of its multicolumned interambulacra. Others have noted its resemblance to an immature of an arbacioid and have postulated that it was ancestral to the arbacioids.

Four Karnian species are known from other than the St. Cassian Beds. Fell's (1950) Dicyclocidaris denticulata from New Zealand is a typical miocidarid as are Bather's two species from Bakony: Triadocidaris persimilis of St. Cassian age and T. immunita from the late Karnian (Raiblian). Although these species are based only on fragments, they can be generically identified.

A third species described by Bather from the Raiblian of Bakony is the earliest echinoid known in the Triassic that is not typically cidaroid (except for the aberrant Tiarechinidae). Although only fragments have been found of this species, Hemipedina? incipiens Bather, enough is known to indicate that it is intermediate in its morphological characters between a miocidarid and pedinoid. It has the denticles on its interambulacral plates typical of a miocidarid, such as Triadocidaris, and the interambulacral lantern supports of a cidaroid. The more advanced features of a pedinoid are evident also: wide interambulacra, relatively small primary tubercles, and large, serially arranged secondary tubercles.

It is later in the Norian that the first certain pedinoid is found, Hemipedina hudsoni, new species. This species is more advanced than Hemipedina? incipiens. Its lantern supports are in the ambulacra, typical of a pedinoid; it lacks denticles on its interambulacral plates. No other well-preserved echinoids have been found in the Norian.

Four species are known from the Rhaetian: two species of cidaroids, one pedinoid, and the earliest hemicidaroid. One of the cidarids, Paracidaris toucasi (Cotteau), is based on an extremely wellpreserved specimen, which was in the Cotteau Collection but can no longer be located. The other cidarid, $P$. jeanneti Lambert, is based on poorer material but clearly belongs to this genus. The pedinoid, Diademopsis? desori (Stoppani) has never 
been well described or illustrated; and unfortunately, all the type specimens have been lost. One cannot be certain of its generic identification, but it is clearly a noncidaroid and probably a pedinoid.

The type specimen of the earliest hemicidaroid, Pseudodiadema silbinense Stefanini, is also lost. Stefanini's description and illustration are sufficient to show that it is a hemicidaroid and, therefore, the oldest known member of the superorder Echinacea. Although no teeth have been found of this species, they were probably keeled, a character typical of this order. This is the only echinoid known from the Triassic that is suspected of having had keeled teeth.

In summary, the echinoids of the Early and Middle Triassic were all miocidarids with flexible tests and simple ambulacra lacking any compounding of the plates. At the beginning of the Late Triassic, the first rigid cidaroids appear and also the first cidaroids having imperforate tubercles, nonconjugate pore-pairs, and incipient compounding of plates. The first noncidaroid, a pedinoid, appears later in the Raiblian. Finally in the Rhaetian the first hemicidaroid appears.

\section{Abbreviations for Institutions}

BMNH British Museum (Natural History), London, England

BSPG Bayerische Staatssammlung für Pälaontologie und Historische Geologie, Munich, West Germany

GB Geologische Bundesanstalt, Vienna, Austria

IGP Institut für Geologie und Paläontologie der Universität, Tübingen, West Germany

IGPB Instituto dí Geologia e Paleontología, Università dí Bologna, Italy

MCA Museo di Cortina d'Ampezzo, Cortina d'Ampezzo, Italy

NM Naturhistorische Museum, Vienna, Austria

NMNH National Museum of Natural History, Smithsonian Institution, Washington, D. C. (Some specimens use acronym "USNM" for former United States National Museum.)

NZGS New Zealand Geological Survey, Wellington, New Zealand

PIM Paläontologisches Institut und Museum, Universität Zürich, Zürich, Switzerland

\section{Acknowledgments}

I am particularly indebted to Rinaldo Zardini of Cortina d'Ampezzo, Italy, who made available his great collection of St. Cassian echinoids. He per- mitted me to study the thousands of specimens and fragments that he has unearthed over the last forty years. This collection is the most significant of all the Triassic material known. During my visit to Cortina in September 1975, he not only guided me to most of his localities (making it possible to collect from these sites), but he also described the stratigraphic relationships of the beds. Mr. Zardini has assembled the largest collection of Triassic fossils in the world and has, with characteristic generosity, made these collections available to specialists throughout the world. His collection is now housed and beautifully exhibited in the Museo di Cortina d'Ampezzo.

I thank Dr. David L. Pawson of the National Museum of Natural History, Smithsonian Institution, and Professor J. Wyatt Durham of the University of California, Berkeley, for reading the manuscript and for making many useful suggestions. Miss Mary Hurd Lawson, museum technician, did the photography, helped to sort the St. Cassian fragments, and assisted in many other ways in the writing of this paper. Figures 1 and 2 were made by Larry B. Isham, scientific illustrator.

Drs. Riccardo Assereto of the Istítuto di Geologia at the Università dí Milano and Norman J. Silberling of Stanford University provided valuable stratigraphic information and modern dates for some of the Triassic formations. Dr. Richard P. S. Jefferies of the British Museum (Natural History) most kindly permitted me to study the specimen of a new species from Arabia.

Many curators lent Triassic echinoids from their collections or helped in the search for lost specimens. I thank the following: Dr. H. K. Erben, Geologisch-Paläontologisches Institute der Rheinischer Friedrich-Wilhelms-Universität, Bonn; Dr. Volker Fahlbusch, Bayerische Staatssammlung für Paläontologie u. historische Geologie, Munich; Dr. E. Montanaro Gallitelli, Instítuto dí Paleontología, Uníversítà dí Modena; Dr. Richard V. Melville, Institute of Geological Sciences, London; Dr. Hugh G. Owen, British Museum (Natural History), London; Dr. ssa Antonietta Padovani, Instítuto dí Geologia e Paleontología, Università dí Bologna; Dr. Daniel Pajaud, Laboratoire de Paléontologie des Invertébrés, Université de Paris; Madame Peyré and Dr. J. Manivit, Centre d'Études et de Recherches de Paléontologie Biostratigraphique, Université de Paris- 
Sud Centre d'Orsay; Dr. Giovanni Pinna, Museo Civico di Storia Naturale, Milan; Dr. Hans Rieber, Paläontologisches Institut und Museum, Universität Zürich; Dr. Jean Roman, Muséum National d'Histoire Naturelle, Institut de Paléontologie, Paris; Drs. A. W. Ruttner and Harald Lobitzer, Geologische Bundesanstalt, Vienna; Dr. Ortwin Schultz,
Naturhistorisches Museum, Vienna; Drs. Jobst Wendt and Frank Westphal, Institut und Museum für Geologie und Paläontologie, Universität Tübingen; Dr. H. Zapfe, Paläontologisches Institut, Universität der Wien, Vienna; Dr. Hans K. Zöbelein, Bayerische Staatssammlung für Paläontologie $u$. historische Geologie, Munich.

\section{Early Triassic: Scythian}

Family MIOCIDARIDAE Durham and Melville

Genus Miocidaris Döderlein

Miocidaris pakistanensis Linck

Plate 1: figure 1

Miocidaris pakistanensis Linck, 1955:489, figs. 1-4.

This species has been carefully described by Linck and no redescription is necessary. I have studied the holotype and include new photographs of it. This species is similar to the other Early Triassic echinoid Lenticidaris utahensis Kier in having a very flexible adapical surface. This flexibility apparently is a primitive character, for it is less developed in Late Triassic miocidarids.

Location of Type SPEcimen.-IGP, Ech. 1058/1.

OcCURRENCE.-Early Triassic, Scythian ("Untere
Ceratiten-Schichten"), Salt Range, Fundort Mittialiwani bei Chhidru, Pakistan.

\section{Genus Lenticidaris Kier}

\section{Lenticidaris utahensis Kier}

Plate 1: figures 2, 3

Lenticidaris utahensis Kier, 1968:1000, fig. 1, pl. 121: figs. 1, 2, pl. 122: fig. 103, pl. 123: figs. 3-9.

This species has just recently been described, and I have nothing new to add to its description. The species is of special interest because of its strongly imbricate adapical surface.

Location of Type SPEcimens.-USNM S5087S5096.

OCCURRence.-Early Triassic, Scythian, Virgin Formation, lower part of Moenkopi Group, 14 km SW of St. George, Utah.

\section{Middle Triassic: Ladinian}

Family MIOCIDARIDAE Durham and Melville

\section{Genus Serpianotiaris Jeannet}

\section{Serpianotiaris hescheleri (Jeannet)}

Plate 2: figures 1, 2

Miocidaris (Serpianotiaris) hescheleri Jeannet, 1933:1, figs. 1-2, pl. 30: figs. 1-13.

Serpianotiaris hescheleri (Jeannet).-Mortensen, 1935:298, figs. 158a-c.-Fell. 1966b:U366a, fig. 271(1)a-c.

Dr. Hans Rieber of the Paläontologisches Institut und Museum at the University of Zurich, Switzerland, has most kindly sent me a superb cast and photographs (Plate 2: figures 1, 2) of the holotype housed in his institution. Study of this material reveals no characters not mentioned in Jeannet's thorough description (except for the presence of a cortex layer on some of the spines) so no redescription is warranted here.

Mortensen (1935:298) believed that this species could not be a cidaroid because of the presence of three characters he thought absent in all cidaroids: the presence of two rows of large secondary tubercles in each interambulacrum, the lack of a cortex layer and collar on the spines, and the rounded, projecting adoral edges of the interambulacra. However, I can see on several of the spines a slightly developed collar; and some appear to have a thin cortex layer. Furthermore, no cortex layer or collar is present on Lenticidaris utahensis Kier, a species that is defi- 
nitely' a cidaroid, so the absence of a cortex layer can no longer be considered as excluding a species from being considered a cidaroid. Some Triassic cidaroids such as Levicidaris zardinia, new species, Zardinechinus lancedelli (Zardini), Triadocidaris venusta (Münster), Megaporocidaris mariana, new species, and Lenticidaris utahensis Kier, also have the adoral edges of their interambulacra rounded. Only in having extra rows of tubercles does Serpianotiaris hescheleri differ from other Triassic cida- roids. I agree with Jeannet (1933:1) that the species belongs with the miocidarids. Its imbricate plates with the interambulacra denticulate at their adradial margins and beveling over the ambulacra and large, perforate, crenulate tubercles are characters typical of Miocidaris. It is distinguished from this genus only by the extra tubercles.

Occurrence.-Middle Triassic, Ladinian, from near Serpiano (Aqua del Ghiffo, Tessin meridional), Switzerland.

\section{Late Triassic: Karnian}

\section{SPECIES FROM THE ST. CASSIAN BEDS}

\section{Localities}

Presumably the material described from the St. Cassian Beds by Münster and Laube came from localities near St. Cassiano, but detailed locality information is not given by either author. Mr. Zardini's specimens were collected over a period of forty years from many different localities. I visited most of these sites with Mr. Zardini in the fall of
1975; and although it is still possible to collect echinoid fragments, they are rare. According to Mr. Zardini (1975: pers. comm.), new sites are made available when fresh exposures result from landslides or new excavations. The St. Cassian Beds are very extensive in the area around Cortina d'Ampezzo, and it can be expected that many more important collections will be made from them. Mr.

\section{Key to the Echinoids from the St. Cassian Beds}

1. More than two columns of plates in each interambulacrum

Two columns of plates in each interambulacrum

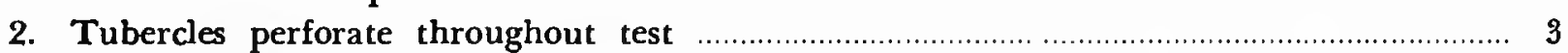

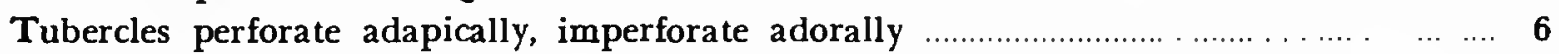

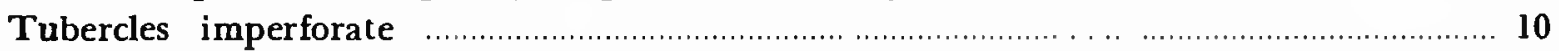

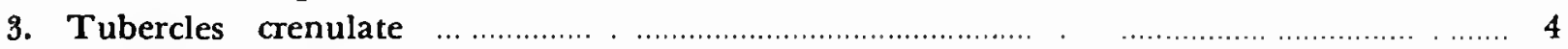

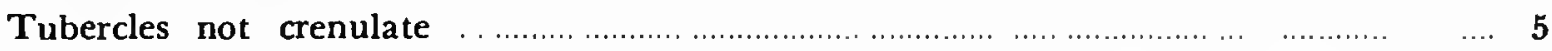

4. Test small, low, few interambulacral plates

Paurocidaris rinbianchi (Zardini), new combination

Test large, many interambulacral plates Polycidaris regularis (Münster)

5. Ambulacra extend to apical system, ambulacral plates more numerous, mamelons large ...

Zardinechinus lancedelli (Zardini), new combination

Ambulacra not extending to apical system, few ambulacral plates

Mikrocidaris pentagona (Münster)

6. Tubercles crenulate ........................ Leurocidaris montanaro (Zardini), new combination

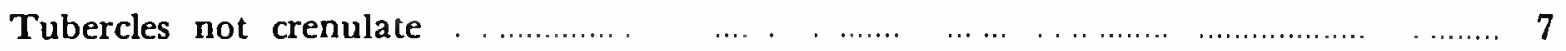

7. Scrobicules transversely elongated ............................. . . . . . . . . .

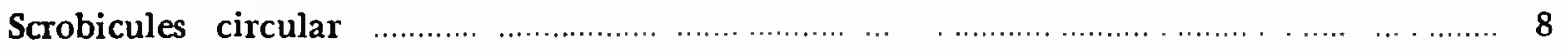

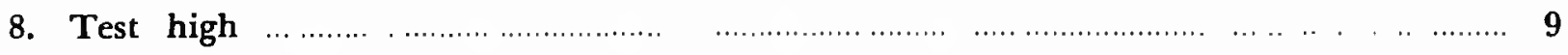

Test low .................................................... Triadocidaris venusta (Münster)

9. Few interambulacral plates .................................... Triadocidaris subsimilis (Münster)

Numerous interambulacral plates ...... Triadocidaris giauensis (Zardini), new combination

10. Test circular, ambulacral plates low ......................... Levicidaris zardinia, new species

Test pentagonal, ambulacral plates high ............ Megaporocidaris mariana, new species 
Zardini's magnificent collection of St. Cassian fossils is housed in the Museo di Cortina d'Ampezzo, where they are well exhibited and available for study.

The echinoids occur in gray and brown limestones (Zardini, 1973a) associated with a rich fauna of corals, sponges, brachiopods, and mollusks. The fossils are extremely well preserved. Aragonite is still present in the corals and sponges, and many of the mollusks retain their color markings. Zardini (1973b:4) estimates that over 800 invertebrate species are present. Although the localities cover a large area, Zardini (1976, personal correspondence) believes that these beds were deposited at approximately the same time in a similar shallow coral reef-lagoon environment. He bases this conclusion on the presence of many of the same species at all these localities.

The echinoids described herein came from the following localities:

Alpe di Specie: SW of base of Mt. Specie, approximately 12 km NE of Cortina d'Ampezzo, Dolomites, Italy.

Boa Staolin: $1 \mathrm{~km}$ NE of Alverà, approx. $2.5 \mathrm{~km} \mathrm{NE}$ of Cortina d'Ampezzo, Dolomites, Italy.

Campo: Approximately $2.01 \mathrm{~km} \mathrm{~S}$ of Cortina d'Ampezzo, Dolomites, Italy.

Cianzopé: $2.5 \mathrm{~km} \mathrm{E}$ of Lago Bai di Dones, approximately $5.5 \mathrm{~km} \mathrm{~W}$ of Cortina d'Ampezzo, Dolomites, Italy.

Forcella Giau: $2.5 \mathrm{~km}$ NE of Selva di Cadore, approximately $9 \mathrm{~km}$ SW of Cortina d'Ampezzo, Dolomites, Italy.

Milieres: $0.5 \mathrm{~km} \mathrm{~W}$ of Campo di Sotto, a town $2.25 \mathrm{~km} \mathrm{~S}$ of Cortina d'Ampezzo, Dolomites, Italy.

Misurina: $2 \mathrm{~km}$ E of base of Mt. Cristallino, $10.5 \mathrm{~km} \mathrm{NE}$ of Cortina d'Ampezzo, Dolomites, Italy.

Rumerlo: $0.25-0.5 \mathrm{~km} \mathrm{~S}$ of Rumerlo, town $2.5 \mathrm{~km} \mathrm{~W}$ of Cortina d'Ampezzo, Italy.

Tamarin: $300 \mathrm{~m} \mathrm{NE}$ of Lake Tamarin, approximately $3 \mathrm{~km}$ NE of Cortina d'Ampezzo, Dolomites, Italy.

\section{Family MIOCIDARIDAE Durham and Melville}

\section{Genus Triadocidaris Döderlein}

\section{Triadocidaris subsimilis (Münster)}

Figure 3, Plate 4: figures 3-6, Platf. 5: figure 1

Cidaris subsimilis Münster, in Wissmann and Münster, 1841: 40, pl. 3: fig. 2-Laube, 1865a:280, pl. 8b: fig. 4, pl. 9: fig. 1.

Triadocidaris subsimilis (Münster).-Döderlein, 1887:39.Bather, 1909:69-76, 78, 93-94, 244, 259.-Venzo, 1934:151, pl. 13: fig. 7.-Kier, 1974:17, 43, 44, 71, 79, fig. $41 \mathrm{~A}$.
Two specimens of Münster's three syntypes (AS VII 437, in BSPG) are only single interambulacral plates, but the third includes part of two interambulacra and an ambulacrum. This specimen was considered by Bather (1909:70) to be the holotype; but because Münster did not indicate which of his three specimens was the holotype, Bather's statement that one was the holotype constitutes designation of it as the lectotype. It is figured on Münster's plate 3: figure 2 (with the image reversed and turned upside down), and on my Plate 4: figure 3. It appears to be the same specimen figured by Laube (1865a, pl. 9: fig. lc). It is $17.7 \mathrm{~mm}$ wide and $16.5 \mathrm{~mm}$ high and apparently comes from the ambital region of the test. Portions of six plates are present in one interambulacrum, but only a small part of two are present in the other. The mamelon is preserved on three of the plates. It is prominent, rising $1.6 \mathrm{~mm}$ above the parapet of the platform, circular in outline when viewed from above, and sharply undercut. The two more adapical mamelons are perforate with foramina elongated dorsoventrally; the more adoral mamelon is imperforate. The boss has a definite platform with a slightly raised parapet. The scrobicule is slightly depressed below the general level of the test and lacks a basai terrace. Only one plate has a complete ring of scrobicular tubercles preserved with 13 tubercles and a small elongate node separating each tubercle. The scrobicular rings of two of the adjacent plates are in contact with each other, but more widely separated $(1.5-2.3 \mathrm{~mm}$ ) between others. A few, irregularly arranged nodes are present in these areas outside of the scrobicular rings.

The ambulacrum is slightly arcuate and $3.1 \mathrm{~mm}$ wide. It is composed of primary plates with 16 plates abutting against a single interambulacral plate. Each plate curves adapically near the perradial suture. Most of the plates bear a single node between the inner pore and the perradial suture except the more adoral plates in which this node is absent on some of the alternate plates. These plates lacking nodes narrow towards the perradial suture. A high protuberance is present between the pores of each pore-pair. The ambulacral plates bevel under the interambulacra.

The orientation of this specimen can be determined by the fact that in this species the ambulacral plates at the perradial suture curve slightly adapi- 


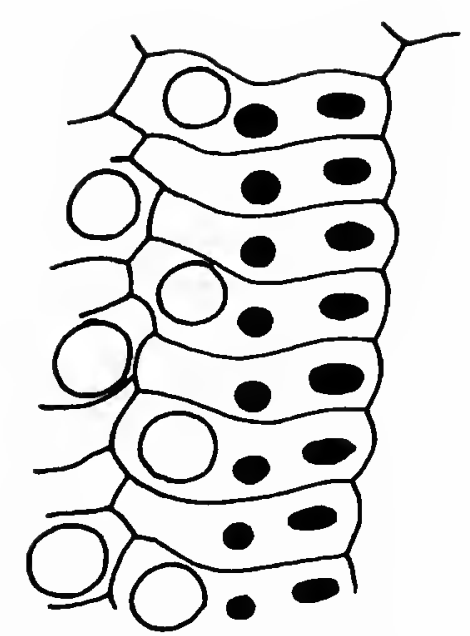

Figure 3.-Triadocidaris subsimilis (Münster), view of portion of an ambulacrum at the ambitus showing the widening of every other plate or every third near the perradial suture, $\times 9$. (For photographs of this specimen, see Plate 4: figures 4-6.)

cally. This is shown in Laube's (1865a, pl. 8: fig. 4) figured specimen (described below) in which the apical system is present and the orientation of the test is known.

Through the kindness of Dr. Ortwin Schultz of the Naturhistorische Museum in Vienna, I have been able to borrow the specimen that Laube figured. It is fairly complete, but his illustration is an inaccurate reconstruction. The figure shows perforate primary tubercles; but, all the tubercles on the specimen are imperforate. None of the adapical tubercles have their mamelons preserved, so it is not possible to know whether this specimen is similar to the lectotype in having the adoral tubercles imperforate and the adapical tubercles perforate. It is similar in all other respects to the lectotype in the width of the ambulacrum, number of ambulacral plates adjacent to an interambulacral plate, and number and position of the scrobicular tubercles. Because this is the best preserved specimen of this species, it is described in detail below and figured on Plate 4: figures 4-6.

MATERIAL.-The specimen is partially flattened and is $25 \mathrm{~mm}$ wide and $15 \mathrm{~mm}$ high. It was probably approximately $23 \mathrm{~mm}$ in horizontal diameter. The peristomial region is destroyed.

Apical System.- This is one of the few Triassic echinoids known with any part of its apical system preserved. The system was originally an approximate $13 \mathrm{~mm}$ in diameter with a madreporic genital plate slightly larger than the others. Each genital plate has a single pore with a raised rim encircling it. A slight rim occurs on the inner edge of each genital plate forming a continuous rim around the periproct. Two to four secondary tubercles are present on each genital plate. The periproctal opening was probably subcircular originally. The ocular plates are exsert, imbricating over the genital plates, and are approximately one-half as large as the genital plates.

AMBLLACRA.-The ambulacra are slightly arcuate, and their width remains approximately the same throughout their length. Each ambulacrum is $2.6 \mathrm{~mm}$ wide (11 percent $\mathrm{D}$ ). There are 92 plates in an ambulacrum (both columns) with approximately 16 plates abutting against a single interambulacrum plate. The plates are all primaries; but every other plate (or in some cases every third) near the anbitus is wider near the perradial suture, where the plates curve adapically (Figure 3; Plate 4: figure 5). A seconclary tubercle occurs on these wider plates. The outer pore of each pore-pair is more elongated than the inner, and a high protuberance (Plate 4: figure 5) separates the pores. The ambulacra bevel under the interambulacra.

INTERAMBULACRA.-Each area has seven plates (both columns) and all the plates bear a large tubercle except the first (adapical) plate in. the right column of each area and the last plate (adoral) in either the right or left column. The primary tubercles have a well-developed scrobicular circle $5.5 \mathrm{~mm}$ in diameter with $15-17$ secondary tubercles in each ring. The scrobicule is on the same level as the rest of the test and gently rises to the boss. The mamelon is circular and undercut. The mamelons are preserved only on the tubercles at or below the ambitus. All of these are imperforate.

Remarks.-The widening of some of the ambulacral plates near the perradial suture and the presence of a tubercle on this widened area and its absence on the narrower, intervening plates indicates the development of a primitive compounding of these plates.

Laube's Other Specimens.-Dr. A. W. Ruttner of the Geologische Bundesanstalt, Vienna, very kindly permitted me to study the specimen shown in Laube's (1865a) plate 9: figures la, b. It consists of a part of two interambulacral plates. It is similar to Münster's specimens and is of special interest in that it shows clearly the grooves on the 
inside of the plates where the interambulacrum bevels over the ambulacrum (Plate 5: figure 1). The specimen figured in Laube's (1865a) plate 9: figure lc is not present at Vienna and appears to be Münster's lectotype. Laube (1865a:280) states that the specimen figured on his plate 9: figure la is one of Münster's original specimens; but it differs from all Münster's syntypes. Presumably, he was referring to his plate 9: figure $1 c$, not la.

OCCURRENCF.-The precise localities for Münster's and Laube's specimens are not known except that they came from the St. Cassian Beds near St. Cassiano. One specimen in the Zardini collection is from Alpe di Specie and one from Misurina.

\section{Triadocidaris suessii (Laube)}

Plate 5: figures 2-4

Cidaris suessii Laube, 1865a:282, pl. 9: figs. 11, 11 .

Triadocidaris suessii (Laube).-Döderlein, 1887:39.-Lambert, 1900:42.-Bather, 1909:69, 75, 76, 78.

Material.-Laube's two type specimens from the St. Cassian Beds were borrowed from the Geologische Bundesanstalt in Vienna. His figured specimen is selected here as the lectotype. Each specimen consists of part of a single interambulacrum. The lectotype (Plate 5: figures 3,4) is $16.9 \mathrm{~mm}$ high; although most of an interambulacrum is present, part of the adoral area is missing. The specimen is $12.4 \mathrm{~mm}$ wide, the width of the interambulacrum at the ambitus. Because so little of the specimen is preserved, it is difficult to estimate the original size of the echinoid. Judging from the curvature of the test, it was probably $25-30 \mathrm{~mm}$ in horizontal diameter and $20-22 \mathrm{~mm}$ high. The paralectotype (Plate 5: figure 2) is smaller, $12.0 \mathrm{~mm}$ high and $9.2 \mathrm{~mm}$ wide (the width of the interambulacrum). The echinoid was originally about 13-16 $\mathrm{mm}$ in horizontal diameter and $13 \mathrm{~mm}$ high. The lectotype consists of 13 interambulacral plates with 3-5 missing adorally. The paratype is an interambulacrum composed of 14 plates with at least one missing adorally. Measurements of a tubercle for each specimen are on Table 1.

The primary tubercles on both specimens have circular perforations, well-differentiated and undercut mamelons, and distinct parapets on the platform of their boss. The scrobicules are wider than high, depressed, and nearly confluent, separated transversely by only a single row of secondary tubercles.

Most of the bosses are not crenulate, but several of the tubercles on both specimens have slight notches in the platforms of their bosses that appear to be crenulations (Plate 5: figure 4).

The median tract of secondary tubercles (along the interradial suture) between the scrobicules is approximately $2.3 \mathrm{~mm}$ wide at the ambitus in the lectotype and $1.5 \mathrm{~mm}$ in the paratype.

The interambulacra of both specimens are beveled along their adradial margins, and slight denticulations are present indicating that the interambulacra beveled over the ambulacra as typical of Triadocidaris.

Comparison with Other SPecies.-Triadocidaris suessii is easly distinguished from the other species of this genus from the St. Cassian Beds by its higher test and its transversely elongated scrobicules. The

TABLE 1.-Dimensions (in $\mathrm{mm}$ ) of a tubercle on the ambitus on each specimen of Triadocidaris suessii

\begin{tabular}{|c|c|c|}
\hline Character measured & Lectotype & Paralectotype \\
\hline Height of interambulacral plate & 3.1 & 3.0 \\
\hline 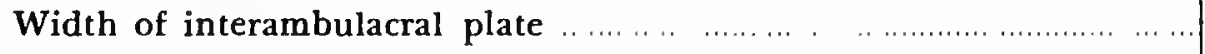 & 6.7 & 5.3 \\
\hline 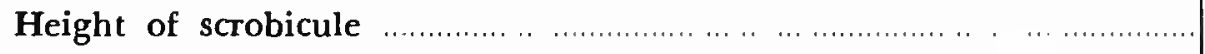 & 2.8 & 2.7 \\
\hline 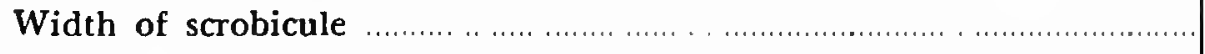 & 4.4 & 3.9 \\
\hline 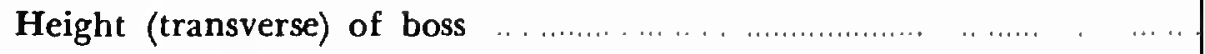 & 2.45 & $*$ \\
\hline 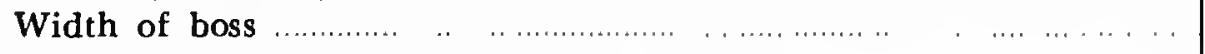 & 2.75 & $\bullet$ \\
\hline 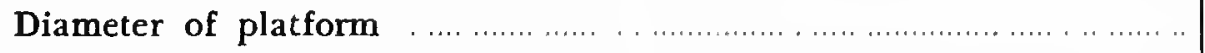 & 1.60 & 1.25 \\
\hline 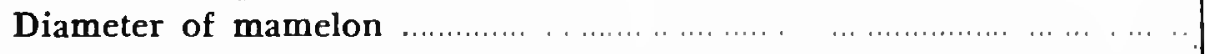 & 1.05 & 0.85 \\
\hline Vertical height from top of mamelon to base of scrobicule & 1.25 & 1.25 \\
\hline
\end{tabular}

- The base of the boss is not clearly differentiated on the paratype. 
scrobicules are more circular in the other species.

OCCURRENCE.-No specimens of this species are present in Zardini's collections. Late Triassic, early Karnian, St. Cassian Beds, Italy.

\section{Triadocidaris venusta (Münster)}

Plate 5: figures 5-8

Cidaris venusta Münster, in Wissmann and Münster, 1841:41, pl. 3: fig. 4.-D'Orbigny, 1849:206.-Desor, 1858:4.-Laube, 1865a:280, pl. 9: fig. 2; 1865b:325.

Triadocidaris venusta (Münster).-Döderlein, 1887:39.Bather, 1909:69, 75.

Microcidaris venusta (Münster).-Lambert, 1900:44.-Lambert and Thiéry, 1910:140.

Mikrocidaris venusta (Münster).-Mortensen, 1928:64, fig. 34:3.-Kier, 1974:17.

?Cidaris gerana Braun, in Wissmann and Münster, 1841:42, pl. 3: fig. 7.-D'Orbigny, 1849:206.-Desor, 1858:4.-Laube, 1865a:282, pl. 9: fig. 10; 1865b:325.-Zardini, 1973a:12, pl. 5: figs. 21, 22, 23.

?Mikrocidaris gerana (Braun).-Döderlein, 1887:39.-Mortensen, 1928:64.

?Microcidaris gerana (Braun).-Lambert and Thiéry, 1910:140.

Material.-The holotype (AS VII 436, in BSPG) is a well-preserved specimen with most of the plate sutures visible. The specimen is very small with a horizontal diameter (D) of only $4.8 \mathrm{~mm}$ and a height of $2.4 \mathrm{~mm}$ ( 50 percent $\mathrm{D}$ ).

Apical System.-No plates of the system are preserved. The system had a width of $2.25 \mathrm{~mm}$ (47 percent $D$ ) and was pentagonal in outer outline with the apices in the ambulacra.

Ambulacra.-The ambulacra are moderately wide with a greatest width of $0.75 \mathrm{~mm}, 40$ percent of the width of the interambulacra. The areas do not narrow when approaching the peristome but have approximately the same width from the ambitus to the peristome. The ambulacra are slightly sinuous, with approximately 36 plates in each area. All the plates are primaries, and each plate bears one node between the pore-pair and the parradial suture forming a vertical series of nodes. The porepairs are oblique with the outer pore of each pair adapical to the inner. The pores are not conjugate; a ridge lies between pores of a pair.

INTERAMBULACRA.-Each area is composed of nine plates, the largest of which is the most adapical one. To the right of this large plate is a small plate lacking a tubercle. The primary tubercles have very large, elevated, perforate mamelons with slightly undercut necks. Their bosses are also strongly elevated and are not crenulate. The scrobicular tubercles extend around the outer margin of the plates with approximately 12 to each primary tubercle. The interambulacra bevel over the ambulacra and have a denticulate margin along the ambulacra.

Peristome.-The peristome is large with a diameter of $2.60 \mathrm{~mm}$ or 54 percent the horizontal diameter of the test. There appear to be slight gill slits (Plate 5: figure 8).

REMARKs.-Although this specimen is very small, there is no evidence that it is immature. Unfortunately, the apical system is not preserved. It is impossible to know whether or not the genital pores were present, but its test is the same size as adults of Mikrocidaris pentagona (Münster).

Mortensen (1928:65) states that the first interambulacral plate extends the whole way across the interambulacrum. This conclusion was probably based upon Münster's poor illustrations. Although the most adapical plate is very large, there is a second smaller plate beside it which lacks a tubercle.

The partly flexible test of this species with the interambulacra beveling over the ambulacra indicates that it belongs among the Miocidaridae. Lambert (1900:44), Lambert and Thiéry (1910:140), and Mortensen (1928:64) considered this species to be Mikrocidaris; but they had not studied specimens of its type-species $M$. pentagona (Münster). Therefore, they did not know that this species has ambulacra that do not reach the apical system and has very high ambulacral plates with large pores. Furthermore, they erroneously believed that the adradial sutures in $T$. venusta are vertical.

The denticulate interambulacral plates beveling over the ambulacra and the very large adapical interambulacral plate with a small tubercle-less plate beside it are features this species shares with the type-species of Triadocidaris subsimilis (Münster), which is also from the St. Cassian Beds. Döderlein and Bather were correct in considering this species to be Triadocidaris.

I have studied five specimens, collected by $\mathrm{Ri}$ naldo Zardini, which appear to belong to this species. Although all of the specimens are small and some of them are slightly distorted by postmortem crushing, they can be distinguished easily 
TABLE 2.-Dimensions of five specinens of Triadocidaris venusta

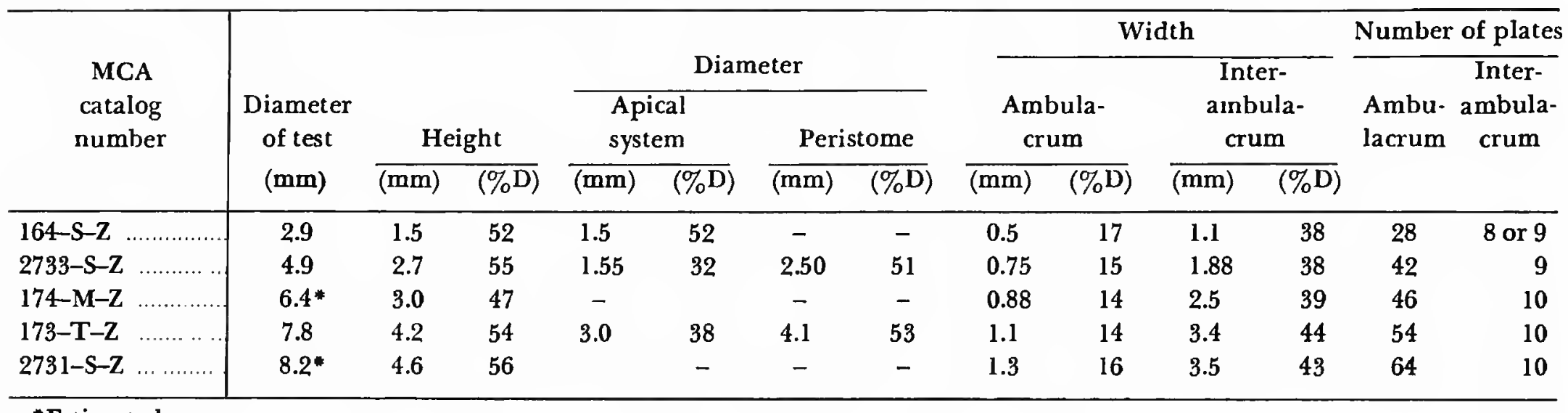

* Estimated.

from the other three species of Triadocidaris known from the St. Cassian Beds.

They cannot belong to Triadocidaris subsimilis Münster because this species has only seven plates in an interambulacrum in a large specimen $(23 \mathrm{~mm}$ in diameter) as compared to only ten in the largest (8.2 $\mathrm{mm}$ in diameter) of these smaller specimens.

They differ from $T$. giauensis (Zardini) in having far lower tests with heights of a maximum 56 percent $\mathrm{D}$ as opposed to 69 percent in $T$. giauensis. Likewise, they can be easily distinguished from $T$. suessii, which has a far higher test and scrobicules that are transversely elongated.

None of the specimens has characters that obviously distinguish them from $T$. venusta. Because of slight differences between these specimens and between these specimens and the holotype of $T$. venusta, they cannot with certainty be referred to this species. Most of these differences may be due to preservation and may not be of significance. Until more specimens have been seen, it is advisable to only tentatively refer them to $T$. venusta. They are figured here on Plate 6 and Plate 7: figures 1-6.

One of the specimens (the smallest, only $2.9 \mathrm{~mm}$ in diameter) is particularly interesting because its apical system is preserved intact. All the ocular plates are exsert. Apparently this is a generic character for they are also exsert in Triadocidaris subsimilis, the only other species of this genus that has been found with an apical system. Only one of the genital plates has any perforations in it (Plate 6: figure 1). It is impossible to know whether one of these is a genital pore or whether all three are madreporite pores. The dimensions of these specimens are in Table 2.

I have studied the holotype (also at Munich, cataloged as AS VII 434) of Cidaris gerana Braun and cannot specifically distinguish it from $T$. venusta. The holotype is not well preserved, but it is similar to the holotype of $T$. venusta in having a large interambulacral plate with a large primary tubercle at the margin with the apical system. A smaller interambulacral plate lacking a tubercle is likewise positioned beside it. There are the same number of plates in each interambulacrum and the tubercles are similar. Because the holotype of Cidaris gerana is poorly preserved, this species is only provisionally considered a synonym of $T$. venusta. It is figured on Plate 7: figures 7-9.

OrCURRENCE.-Zardini's specimens came from Alpe di Specie and Milieres.

\section{Triadocidaris giauensis (Zardini), new combination}

Plate 8: ficures 1, 2

Cidaris giauensis Zardini, 1973a:12, pl. 20: figs. 34a,b.

MatrRial.-The holotype (163-G-Z, in MCA), which is the only known specimen of this species, was lent for study by Mr. Rinaldo Zardini. Although the specimen is only slightly crushed, it is badly weathered; and much of the surface detail is destroyed.

Shape AND Size.-The test was approximately $24.5 \mathrm{~mm}$ in diameter and $17 \mathrm{~mm}$ high $(69$ percent D). Although the test appears to have been rigid, the ambulacra bevel under the interambulacra.

Apical System.-Not known. 
Ambulacra.-The ambulacra are sinuous and narrow, $2.50 \mathrm{~mm}$ wide at the ambitus (10 percent D) and 19 percent the width of an interambulacrum. Although no ambulacrum is preserved throughout its entire length, there were approximately 116 plates in an ambulacrum with 13 or 14 plates abutting against an interambulacrum at the ambitus. All the plates are primaries with nonconjugate pores; a high ridge separates the pores of a pair (Plate 8: figure 2). The outer pore (nearer the adradial suture) is situated slightly adapical of the inner. The pore-pairs or poriferous zones are approximately 65 percent the width of the ambulacrum. Each plate bears a single, small, secondary tubercle between the inner pore of a pore-pair and the perradial suture. Because each plate curves adapically slightly towards the perradial suture, this tubercle is situated slightly adapical to the pore-pair. The ambulacra bevel under the interambulacra.

INTERAMBULACRA.-Each interambulacrum is approximately $13.2 \mathrm{~mm}$ wide at the ambitus (54 percent D). It was probably composed of 14 or 15 plates, but no interambulacrum is complete so it is impossible to be certain of the number of plates.

The primary tubercles adapical to the ambitus have large, slightly undercut mamelons with deep perforations which are elongated dorsoventrally. Most of the mamelons of tubercles at and adoral to the ambitus are broken off. Several adoral ones which remain are imperforate. The scrobicules are depressed slightly below the general level of the test. They are circular and occupy most of each plate. The scrobicules at the ambitus and above are complete, but adoral to the ambitus they are confluent. The scrobicular tubercles are large with 15 tubercles in a ring on a plate immediately adapical to the ambitus. The area between the rings is occupied by many irregularly arranged, secondary tubercles which are approximately one-half as large as the scrobicular tubercles. The tubercles appear to be noncrenulate, but the poor preservation makes it impossible to be certain.

The interambulacra bevel over the ambulacra, and each plate is denticulated along its adradial margin with a denticle protruding over the adjacent ambulacral plates at their transverse sutures.

Peristome.-Unknown.

REMarks.-This species is referred to the Mioci- daridae because its ambulacra bevel under the interambulacra. It has two columns in each interambulacrum, perforate, nonconjugate pores, and uniserial ambulacral plates. With its noncrenulate tubercles and denticulate, interambulacral plates, there is little doubt it belongs to Triadocidaris.

It is similar in general appearance to the typespecies of Triadocidaris, $T$. subsimilis (Münster), also trom the St. Cassian Beds. I have compared it directly to Laube's (1865a, pl. 8b: fig. 4) specimen of this species of the same approximate size, which is described elsewhere in this paper (Figure 3, Plate 4: figures 4-6). The holotype of $T$. giauensis differs in having more interambulacral plates in each column. There are 14 or 15 plates in an interambulacrum as opposed to only 7 in the specimen of $T$. subsimilis of similar size. Furthermore, in $T$. giauensis adjacent ambulacral plates are of the same size and each plate bears a secondary tubercle. In $T$. subsimilis every other plate (or in some cases every third) near the ambitus is wider near the perradial suture. A secondary tubercle is absent on the narrower plates. Finally, in $T$. giauensis the interradial (medial) zones of the interambulacra are wider with more secondary tubercles.

Occurrence.-Forcella Giau.

\section{Family CIDARIDAE Gray}

\section{Genus Mikrocidaris Döderlein}

\section{Mikrocidaris pentagona (Münster)}

Figure 4, Plate 2: figures 3-6, Plate 3, Plate 4: figures 1, 2

Cidaris pentagona Münster, in Wissmann and Münster, 1841:42, pl. 3: fig. 8.-D'Orbigny, 1849:206.-Giebel, 1853:316.-Desor, 1855:4.-Laube, 1865a:280, pl. 9: fig. 3; 1865b:325.

Microcidaris pentagona (Münster).-Döderlein, 1887:39.Lambert and Thiéry, 1910:140.-Mortensen, 1928:64, fig. 34.-Zardini, 1973a:9, pl. 5: figs. 18-19.-Kier, 1974:17, 71, 79.

Cidaris subpentagona Braun, in Wissmann and Münster, 1841:42, pl. 3: fig. 9.-D'Orbigny, 1849:206.-Giebel, 1853:316.-Desor, 1855:4.-Laube, 1865a:282, pl. 9: fig. 9; 1865b:325. [Not Zardini, 1973a:13, pl. 5: figs. 16-17.]

Mikrocidaris subpentagona (Braun).-Döderlein, 1887:39.Lambert and Thiéry, 1910:140.-Mortensen, 1928:64.-Kier, 1974:17.

Dr. Volker Fahlbush in Munich very kindly permitted me to clean and photograph the holotype (AS VII 392, in BSPG). Through the kindness of 


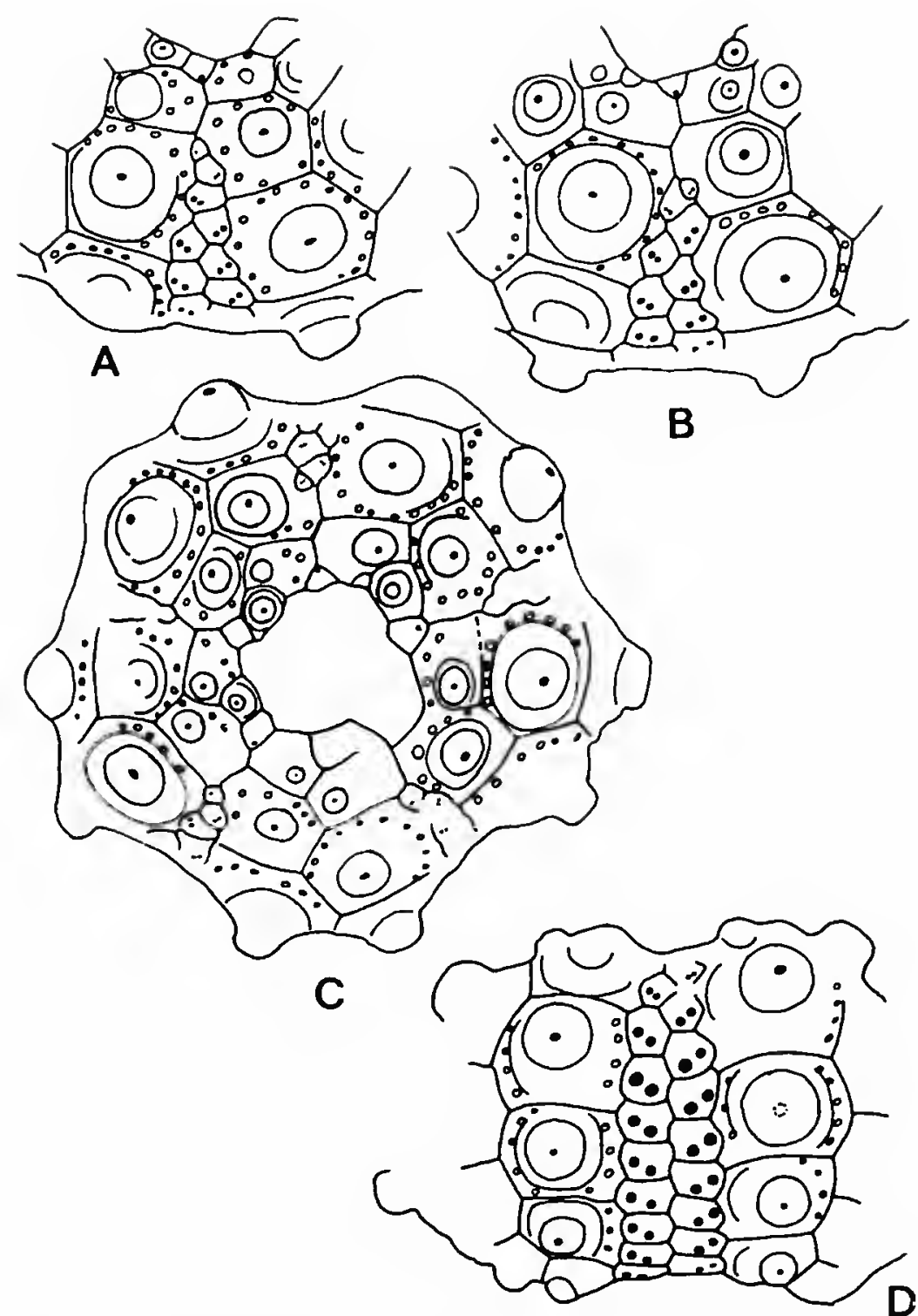

Figure 4.-Mikrocidaris pentagona (Münster): A, B, adapical views of portion of test showing separation of ambulacra from ocular plates; C, adapical; $D$, side views of test. (See Plate 3 for photographs of this specimen; $\times 10$ ).

Dr. A. W. Ruttner in Vienna I was able to do the same with Laube's figured specimen. Münster's and Laube's specimens are clearly conspecific, but Laube's figures are so erroneous that his specimen appears to be quite different. His drawings show far too many ambulacral and interambulacral plates, too small an apical system, and also imperforate tubercles. Neither Münster nor Laube noted that the ambulacra do not reach the apical system in this species.

MATERIAL.-This description is based on four specimens, the holotype (Plate 2: figure 3), Laube's figured specimen (Plate 3), and two specimens figured by Zardini (Plate 2: figures 4-6).

SHAPE AND SIzE.-The marginal outline is pentagonal with apices in the interambulacra. All the specimens are small, $4.6-5.3 \mathrm{~mm}$ in diameter (D), with a height 58-63 percent $D$.

Apical System.-The system is small, diameter 24-28 percent $D$. The ocular plates are small and deeply inserted into the interambulacra (Figure $4 \mathrm{~A}-\mathrm{C})$. The genital plates and the rest of the apical system are absent on all specimens. The outline of the apical system is pentagonal with the apices in the ambulacra.

AmbUlacra.-Each ambulacrum is composed of two columns of narrow, high, hexagonal plates (Figure 4D; Plate 3: figure 3) with large pores. The inner pore of a pair is more adoral than the outer. The ambulacra are 33 percent as wide as the interambulacra and 14-16 percent $D$. The ambulacra do not reach the apical system, being separated from the ocular plates (Figure $4 \mathrm{~A}-\mathrm{C}$ ) by the junction of one or two interambulacral plates. There are 18 plates in each ambulacrum (both columns) in the smallest specimen $4.6 \mathrm{~mm}$ in diameter and 23-24 in the largest (the holotype) $5.3 \mathrm{~mm}$ in diameter. One node on each plate occurs adapically towards the perradial suture (Plate 3: figure 3).

INTERAMBULACRA.-Each interambulacrum has 12-13 plátes with very large tubercles (Plate 2: figure 6), occupying most of the surface of each plate. The mamelons are strongly developed, perforate, and slightly undercut. The parapet is not crenulate, and the boss has gently sloping sides. The scrobicular ring of nodes is complete on some tubercles, but confluent on a few of the larger; the tubercles are largest at the ambitus and just adapical to the ambitus.

PerIsTOMe.-The peristome is subpentagonal (Plate 2: figure 5) with its apices in the interambulacra. It is very large, with its greatest width 50-59 percent of the diameter of the test. There are no gill slits.

Occurrence.-Zardini's specimens came from Forcella Giau and Milieres.

REMARKs.-Although these specimens are very small, they are evidently mature specimens. The fact that the ambulacra are separated from the ocular plates indicates that no further ambulacral plates would have been produced. Kier (1956) has shown that the separation of the interambulacrum from the ocular plates indicates a cessation of production of new plates for the interambulacrum, and presumably the same applies for the separation of 
the ambulacrum. This echinoid exhibits many characters found in the immature of Recent cidaroids such as a large peristome, few plates, large interambulacral plates with large tubercles, and large, high ambulacral plates. Its resemblance in some of these characters and in its general appearance is evident in a comparison (Figure 5) of its test with that of an immature Austrocidaris canaliculata (A. Agassiz), a Recent cidaroid from the Antarctic.

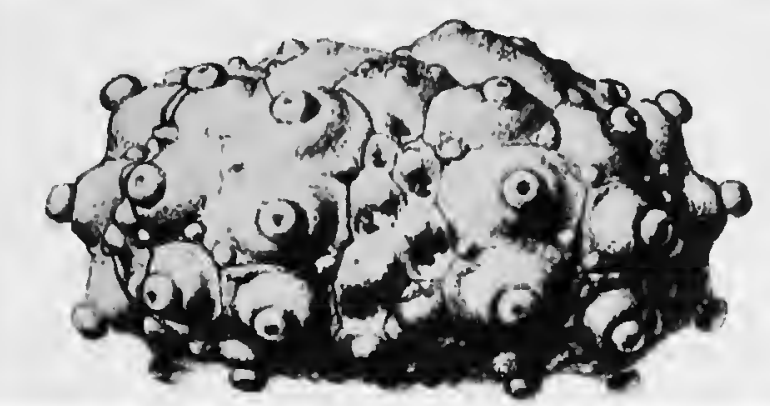

Figure 5.-Austrocidaris canaliculata (A. Agassiz), side view of an immature specimen ( $1.45 \mathrm{~mm}$ in diameter) now living in the Antarctic showing its resemblance for Mikrocidaris pentagona (Münster). Both have a large peristome, few plates, large interambulacral plates, and large, high ambulacral plates. (Photocopied from Lovén, 1892, pl. 2: fig. 8.)

I have cleaned and studied the holotype of Cidaris subpentagona Braun and cannot distinguish it from $M$. pentagona. The two species are similar in having their primary tubercles decrease in size adorally with 12 plates in each area, in having high ambulacral plates which do not extend to the apical system and which have very large porepairs occupying most of the ambulacra, and in having a very large peristome. Cidaris subpentagona is, therefore, considered here to be a junior (it follows $M$. pentagona in the original description) subjective synonym of $M$. pentagona. The holotype of C. subpentagona is figured here on Plate 4: figures $1,2$.

Zardini (1973a:13, pl. 5: figs. 16, 17) referred two specimens to $M$. subpentagona, but one of them (figured on his plate 5: figs. $17 \mathrm{a}, \mathrm{b}, \mathrm{c}$ ) is considered here a holotype of Megaporocidaris mariana, new species. I have not studied the other specimen, but it appears to be too low to be a $M$. pentagona. One of the two specimens Zardini (1973a:9, pl. 5: fig. 18) referred to $M$. pentagona is illustrated here (Plate 2: figures 4-6).

Fell (1966a:U321) provisionally referred Mikro- cidaris to the family Miocidaridae but considered the assignment doubtful because of the lack of imbricating test plates. Probably the genus should be referred to the family Cidaridae and subfamily Cidarinae.

\section{Genus Polycidaris Quenstedt}

Polycidaris regularis (Münster)

Plate 8: figures 3-6

Cidaris regularis Münster, in Wissmann and Münster, 1841:41, pl. 3: fig. 6.-Bather, 1909:101-102.

Henicidaris regularis (Münster).-Agassiz and Desor, 1846: 339.-D'Orbigny, 1849:206.

Hypodiadema regularis (Münster).-Desor, 1858:61.-Laube, 1865a:295, pl. 9: fig. 8; 1865b:326.

Eodiadema regulare (Münster).-Lambert, 1900:34.-Lambert and Thiéry, 1910:177.

This description is based on the holotype (AS VII 435, in BSPG), which is a slightly crushed specimen that was originally about $30 \mathrm{~mm}$ in horizontal diameter and $17 \mathrm{~mm}$ high.

ApICaI. System.-The apical system is missing, but its diameter is estimated to have been $13 \mathrm{~mm}$ or 43 percent of the diameter of the test.

Ambulacra.--Each ambulacrum is straight, not arcuate, and narrow with a width of $3.4 \mathrm{~mm}$ at the ambitus (24 percent width of an interambulacrum), narrowing slightly adorally with a width of $3.0 \mathrm{~mm}$ at the peristomial margin. The plates are all simple primaries without any indication of compounding even adorally nearing the peristome. A single column has 43 plates ( 86 in a single ambulacrum) with 5 plates at the ambitus adjacent to a single interambulacrum plate. The interporiferous zone is narrow, $1.3 \mathrm{~mm}$ wide at the ambitus or 35 percent width of ambulacrum. The pore-pairs are in a straight vertical series; the outer pore of each pair is slightly more elongated transversely than the inner. The pores are not conjugate, having a slight protuberance rising between the pores of a pair. A single node occurs on each plate between the inner pore of a pair and the perradial suture forming two vertical rows of nodes in each ambulacrum. The ambulacra do not bevel under the interambulacra. The adradial sutures between the ambulacra and interambulacra are nearly vertical.

INTERAMBULACRA.-The interambulacral plates 
are low. A plate at the ambitus is $7.9 \mathrm{~mm}$ wide and $2.5 \mathrm{~mm}$ high (height 32 percent of width). Each interambulacrum has 20-24 plates. A primary tubercle is present on each plate except the most adapical plates where it is absent or slightly developed. The tubercle is deeply perforate with a circular perforation as viewed from above and strongly crenulate with approximately 14 crenulations on each tubercle at the ambitus. The scrobicules are deeply depressed below the general surface of the test and are strongly confluent. A plate at the ambitus has a scrobicule $4.3 \mathrm{~mm}$ wide on a plate $7.5 \mathrm{~mm}$ wide (57 percent width of plate). The surface of a plate outside the scrobicule has nodes irregularly arranged and of irregular shape.

Peristome.-The peristome was approximately $14 \mathrm{~mm}$ in diameter or 46 percent of the horizontal diameter of the test. No gill slits are present.

LANTERN SUPPORTs.-The interambulacral apophyses are low and inclined. No projections are present on the ambulacral basicoronal plates.

REMARKs.-Only one specimen is known of this species. Laube's (1865b, pl. 9: fig. 8) figure is of Münster's holotype. This species has erroneously been referred to several noncidaroid genera, presumably because of its smaller primary tubercles. However, it lacks gill slits and has ambulacral plates that are all primaries, including those near the peristome. I have excavated the lantern supports. They are apophyses, interambulacral in position, without any projections on the basicoronal ambulacral plates, which suggests that this species is a cidaroid. Its rigid test with perforate tubercles places it in the family Cidaridae; its crenulate tubercles and nonconjugate pore-pairs, in the subfamily Histocidarinae; and its numerous interambulacral plates, confluent scrobicules, and straight ambulacra, in Polycidaris. It is so similar to the type-species of this genus, P. multiceps (Quenstedt) from the Oxfordian of Germany, that I suspect that this supposedly Triassic specimen of Münster's may really be conspecific with $P$. multiceps and may be from the Oxfordian. Quenstedt's (18721875, pl. 79: fig. 69) figures are not adequate for a comparison. His figure of his Oxfordian specimens show a wider adradial tract (the zone between the primary tubercle and the ambulacra). This may simply be an error of the artist. Unfortunately, the location is unknown of Quenstedt's type specimens of $P$. multiceps. According to Dr.
F. Westphal (pers. comm., 1973), it is not with the other Quenstedt types at the Institut und Museum für Geologie und Paläontologie der Universität Tübingen nor is it at Stuttgart.

\section{Zardinechinus, new genus}

Type-Specles.-Cidaris lancedelli Zardini from the Late Triassic, early Karnian, St. Cassian Beds, Italy.

The test is small and rigid with nonimbricate plates. The ambulacra are composed of primary plates throughout their length. The pores are not conjugate. Most ambulacral plates bear a single secondary tubercle; and most interambulacral plates bear a perforate, noncrenulate primary tubercle.

REMARKs.-This genus has a rigid test with no beveling of the ambulacra under the interambulacra, and, therefore, it cannot be referred to any genera of the Miocidaridae, and must belong among the Cidaridae. Having noncrenulate tubercles, nonconjugate pores, and no sutural pits or grooves, this genus is referred to the subfamily Cidarinae. Of all the genera in this subfamily, it resembles most Plegiocidaris in having simple ambulacra; but it differs in having noncrenulate tubercles and narrower ambulacra.

\section{Zardinechinus lancedelli (Zardini), new combination}

\author{
Plates 9, 10, Plate 11: figures 1-8
}

Cidlaris lancedelli Zardini, 1973a:12, pl. 5: figs. 24a,b. Cidaris admeto.-Zardini, 1973a:12, pl. 5: figs. 34a [adapical view], 34b [not Braun].

Cidaris cfr. admeto._Zardini, 1973a:12, pl. 6: figs. 1la [adapical view], llb [upside down], [not Braun].

MATerIal.-The following description is based on many fragments and on the holotype (172-Mi-L) kindly lent by Mr. Rinaldo Zardini, which is deposited at the Museo di Cortina d'Ampezzo. The holotype is very well preserved, lacking only its apical system. The test is not crushed or distorted, and is little weathered.

Size AND SHAPE.-The test is $10.0 \mathrm{~mm}$ in diameter and is relatively high, $5.9 \mathrm{~mm}$ or 59 percent the diameter of the test (D). The test appears rigid but the interambulacra strongly bevel over the ambulacra. 
Apical System.-No plates are preserved. The diameter of the system in the holotype is $4.4 \mathrm{~mm}$ or 44 percent $D$.

Ambulacra.-In the holotype an ambulacrum (Plate 9: figure 5) attains its greatest width adoral to the ambitus where its width is $1.47 \mathrm{~mm}$ or 14.7 percent $\mathrm{D}$. The plates are all primaries with 56 plates in each ambulacrum. Five or six plates abut an interambulacral plate at the ambitus. The pores are not conjugate; each pore is separated by a prominent, thick, vertical ridge. The pore-pairs are situated in slightly developed peripodia. A ridge runs along the adapical edge of the pore-pair joining it with the vertical ridge that lies between the pores of a pair. The pore-pairs at the ambitus occupy 60 percent of the width of the ambulacrum. The outer pore of a pore-pair (the pore nearer the adradial suture) is situated more adapically than the inner. Each plate curves slightly adapically toward the perradial suture of the ambulacrum. The plates bear a single, secondary tubercle between the inner pore of a pore-pair and the perradial suture. An exception is the first 3 or 4 adoral plates at the peristome, which have a smaller tubercle between the larger tubercle and the perradial suture.

The ambulacra are far wider than appears in an intact specimen. The adjacent interambulacral plates bevel in a low angle over almost one-half the width of an ambulacra. When the interambulacra are in place, they extend almost to the edge of the outer pore of a pore-pair (Plate 10: figure 1, left side of ambulacrum). When an interambulacrum is removed (Plate 10: figure 1, right side of ambulacrum), it can be seen that the width of the ambulacrum is almost twice that visible when the interambulacra are in place. Each ambulacral plate, where it is overlapped by an interambulacral plate, bears a transverse groove extending from outside the outer pore to the edge of the plate (Plate 10: figure 1, right side of photograph; figure 2).

INTERAMBULACRA.-Each interambulacrum in the holotype is approximately $4.05 \mathrm{~mm}$ wide (40.5 percent $\mathrm{D}$ ) and is composed of 14 plates. Each bears a large tubercle except the first plate in one of the columns at the apical system which lacks a tubercle. The tubercles are largest adapically, decreasing continuously in size adorally. The mamelons are prominent with deep circular to longitudinally slit per- forations. Most of the mamelons are slightly undercut. The parapets are generally not crenulate, but in a few specimens crenulations occur on the adoral side of some tubercles (Plate 10: figure 9). The scrobicules are distinct and slightly depressed below the general surface of the test. Adapically, the scrobicules are complete; but at the ambitus and adorally, they are confluent (Plate 9: figures 3,6), with no scrobicular tubercles transversely separating the tubercles. The dimensions of a plate immediately above the ambitus are: width of plate $2.20 \mathrm{~mm}$, height $1.62 \mathrm{~mm}$, diameter of scrobicular ring $1.47 \mathrm{~mm}$, and diameter of mamelon $0.91 \mathrm{~mm}$.

The adradial edge of the interambulacral plates (Plate 10: figure 1) are thin where they bevel at a low angle over the ambulacra. Denticulations are present along the inside of the adradial edges (Plate 10: figure 6). These denticulations are as described by Bather (1909:73) in Triadocidaris with their ridges corresponding in position to the transverse sutures of the ambulacra.

Peristome.-Diameter $5.0 \mathrm{~mm}$ (50 percent D). No gill slits are present.

LANTERN SUPPORTs.-Fortunately, many fragments have their lantern supports intact. These supports are small and are situated at the margin of the ambulacra and interambulacra. The supports are formed by a thickening of the interambulacral plates at their adradial margin at the peristome (Plate 10: figure 6) and by a greater thickening of the ambulacral where they bevel under the interambulacral. This thickening involves two or three of the plates in each half ambulacrum near the peristome (Plate 10: figure 3).

INSIDE OF TEST.-The interambulacral plates tend to thicken medially and thin out towards the adradial and interradial sutures. The result is a deep groove that runs longitudinally along the medial (interradial) suture (Plate 10: figure 6). The plates also thicken at the transverse sutures producing transverse ridges.

Remarks.-Zardini's specimens, referred to $\mathrm{Ci}$ daris admeto Braun (Zardini, 1973a, pl. 5: figs. 34a, b) and Cidaris cfr. admeto (Zardini, 1973a, pl. 6: figs. 1la, b), appear conspecific with the holotype of Zardinechinus lancedelli. Their shape, ambulacra, tuberculation, relative dimensions, and number of plates are indistinguishable from the holotype. The larger specimen (Zardini, 1973a, pl. 6: figs. 11a, b; 
my Plate 11: figures $1-4$ ) is $10 \mathrm{~mm}$ in diameter (estimated) and has 56 plates in each ambulacrum and 14 plates in each interambulacrum. The other specimen (Zardini, 1973a, pl. 5: figs. 34a, b; my Plate 11: figures $5-8$ ) is $7.5 \mathrm{~mm}$ in diameter (estimated) and has 52 plates in each ambulacrum and 12 in each interambulacrum.

As noted elsewhere, the type specimen of Cidaris admeto Braun has been lost. Braun's (in Wissmann and Münster 1841, pl. 3: fig. 3) figure is so inadequate that it is impossible to know the generic or specific characters of this species. Although Zardinechinus lancedelli appears to be similar to Braun's figure of his Cidaris admeto, it seems best to maintain Zardini's species until the type specimen has been found.

Over 100 fragments, mainly interambulacra, have been collected by Mr. Zardini at Campo. Some of these pieces differ from the holotype by their tubercles, having slit-like rather than round perforations, a few crenulations on the adoral side of some tubercles, and a broader field of secondary tubercles along the medial interradial suture (Plate 10: figure 8). At first I thought that these might represent another species of Zardinechinus; but there are some fragments which have elongated perforations and narrow secondary fields lacking crenulations (Plate 10: figure 9). Because of the presence of these transitional forms, it seems advisable not to erect a separate species. Only when complete tests have been found of specimens with these characters can it be decided, with some degree of certainty, whether or not a second species is present.

Occurrences.-Fragments of this species are most common at Campo. The holotype is from Milieres, while the other figured intact specimens are from Alpe di Specie and Cianzopé. Other specimens and fragments are from Rumerlo, Misurina, Milieres, and Tamarin.

\section{Paurocidaris, new genus}

TyPE-SPEC1Es.-Cidaris rinbianchi Zardini from the Late Triassic, early Karnian, St. Cassian Beds, Italy.

The test is small and rigid with nonimbricate plates. The ambulacra are wide and composed of primary plates throughout their length. The pores are not conjugate. Each ambulacral plate bears a single, large, secondary tubercle which, because of the adapical curving of the plate, is situated adapical of the pore-pair. The interambulacra are composed of a few, large plates each bearing a large, perforate, crenulate tubercle.

REMARKs.--This genus has a rigid test with no beveling of the ambulacra under the interambulacra. Therefore, it cannot be referred to any genera of the Miocidaridae and must belong to the $\mathrm{Ci}$ daridae. Because its spines and pedicellariae are not known, the assignment to a subfamily is diffcult. It has nonconjugate pores and no sutural pits or grooves and could belong either to the Histocidarinae or the Cidarinae. Both of the subfamilies are mainly distinguished by the character of their spines and pedicellariae. If compared to the Histocidarinae, it differs from the Jurassic Polycidaris and Procidaris in having a smaller, lower test and far larger and fewer interambulacral plates. Among the Cidarinae, it resembles most Plegiocidaris in its simple ambulacra and crenulate tubercles but differs in its smaller test with broader ambulacra composed of far fewer plates in each column.

Paurocidaris rinbianchi resembles in general appearance Triadocidaris venusta (Münster) also from the St. Cassian Beds. Both species have small, low tests with few interambulacral plates, large prominent primary tubercles, and similar ambulacra. Paurocidaris rinbianchi differs in having crenulate tubercles and a rigid test in which the ambulacra do not bevel under the interambulacra.

\section{Paurocidaris rinbianchi (Zardini), new combination}

Figure 6, Plate 11: ficures 9, 10, Plate 12: ficures 1-4

Cidaris rinbianchi Zardini, 1973a:11, pl. 5: figs. 1, 2, pl. 6: fig. 12.

Material.-Zardini based this species on three specimens: two tests and a portion of an interambulacrum. These specimens were kindly lent to me by Zardini and are described below.

The holotype (125-M-Z, in MCA), figured by Zardini (1973a, pl. 5: fig. la, b), is a well-preserved specimen with only the apical system and a small portion of some of the adoral plates absent. Its horizontal diameter is $7.7 \mathrm{~mm}$ and its height 3.8 $\mathrm{mm}$ ( 49 percent the diameter of the test). Although 
the test is slightly crushed, it may have originally been only slightly higher. The apical system is large, $3.25 \mathrm{~mm}$ wide or 42 percent the diameter of the test. The peristome is also large with a diameter of $3.75 \mathrm{~mm}$ or 49 percent of the diameter of the test.

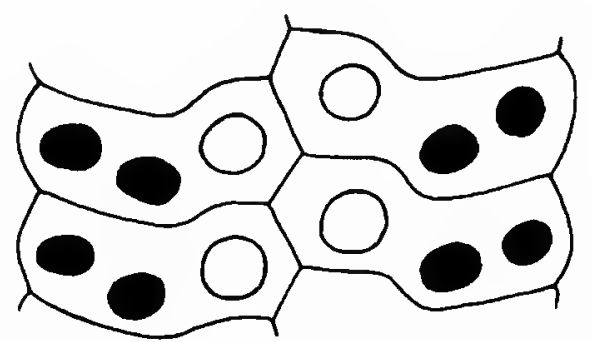

Flgure 6.-Paurocidaris rinbianchi (Zardini), portion of an ambulacrum of the holotype at the ambitus showing the adapical curving of the plates near the median suture, $\times 40$. (For photographs of this specimen, see Plate 9; Plate 12: figures 1, 2.)

An ambulacrum is $1.27 \mathrm{~mm}$ wide at the ambitus or 16.5 percent of the diameter of the test. The ambulacral plates are all primaries with 56 plates in each ambulacrum and 6-8 plates abutting an interambulacral plate at the ambitus. The pores are not conjugate. Each pore is separated by a vertical ridge. The pore-pairs are situated in peripodia in which a high ridge runs along the adapical edge (Plate 12: figure 2) of the pore-pair with a vertical ridge extending down between and separating the pores of a pore-pair. The pore-pairs occupy little more than one-half the width of the ambulacra. The outer pore of a pore-pair (the pore nearer the adradial suture) is situated more adapically than the inner. Each plate curves sharply adapically (Figure 6) nearing the perradial or median suture of the ambulacrum. Each plate, including those nearest the peristome, bears a single, large, secondary tubercle. Because of this adapical curving of the plate, it is situated adapical of the pore-pair.

The interambulacra are composed of a few, large plates with 9 or 10 plates in each interambulacrum. An interambulacrum is $3.15 \mathrm{~mm}$ wide at the ambitus or 41 percent of the diameter of the test. The plates are largest adapically except for the adapical plate in the right column (as viewed from above) of each interambulacrum. This is small and lacks a tubercle. The tubercles (Plate 12: figures 1, 2) are large, covering most of the surface of each plate. The mamelons are prominent with deep perforations, which are slightly elongated dorsoventrally. Most of the mamelons are slightly undercut. The parapets are distinctly crenulate with approximately 14 crenulations on a tubercle at the ambitus. A slight basal terrace is present on the larger, more adapical tubercles. The scrobicules are flush or slightly below the general surface of the test. The scrobicular tubercles are larger than the secondary tubercles outside of the scrobicular ring and form a circle occupying most of each plate. The adapical plates (Plate 11: figure 9) have scrobicular rings which are complete. The more adoral plates (Plate 12: figure 2) have confluent rings along their transverse sutures in which only a single row of scrobicular tubercles separate the scrobicules of vertically adjacent plates. Eaçh scrobicular ring above the ambitus has 16-18 tubercles.

The test appears to have been rigid. None of the plates have shifted over each other along their sutures. In particular the interambulacra have not shifted over the ambulacra at any place on the test. At the peristome the plane of the suture between the ambulacra and interambulacra appears to be nearly vertical, but one is uncertain because of the difficulty of distinguishing sutures from fractures.

The figured paratype (Zardini, 1973a, pl. 5: figs. 2a, b; my Plate 12: figures 3,4 ) is a smaller specimen (diameter $3.6 \mathrm{~mm}$ ), which is not as well preserved as the holotype. Its apical system is missing, and the test is weathered and fractured. It shows enough characters, however, to determine that it is conspecific with the holotype. Its tuberculation is similar. Its ambulacral plates are like those in the holotype in that each bears a single large secondary tubercle situated perradially where the plate curves adapically. As in the holotype, its interambulacra are composed of a small number $(8-10)$ of large plates. It only differs from the holotype in having the small, nontuberculate, adapical plate on the left instead of on the right in each area. Being a smaller specimen, it has fewer plates in each ambulacrum (28), a slightly larger (relative to the size of the test) apical system (diameter 45 percent of diameter of the test), larger peristome (55 percent), but approximately the same height (47 percent diameter of test). This specimen like the holotype appears not to have had a flexible test. 
None of the plates have slipped over each other at their sutures.

The third figured paratype (Zardini, 1973a, pl. 6: fig. 12; my Plate 12: figure 5), is a portion of an interambulacrum lacking its adapical or adoral extremities. It is composed of 6 plates. The mamelons are broken off; and, therefore, it is not known whether they were perforate or whether the tubercles were crenulate. This specimen does not appear to belong to this species. Its interambulacrum is less curved than in the holotype suggesting that its test was far higher. Furthermore, its scrobicules are more confluent with fewer scrobicular tubercles transversely separating adjacent tubercles of the same vertical series.

\section{Leurocidaris, new genus}

TYPE-SPECIES.-Cidaris montanaro Zardini from the Late Triassic, early Karnian, St. Cassian Beds, Italy.

The test is small and rigid with nonimbricate plates. The ambulacra are narrow and are composed of primary plates throughout their entire length. The pores are not conjugate. Each plate bears at least three small, equal sized, irregularly arranged, secondary tubercles. The interambulacra are composed of a few, large plates each bearing a prominent tubercle that is perforate on the adapical plates but imperforate adoral to the ambitus. The parapets are crenulate; and the scrobicules are small, lacking a scrobicular ring of tubercles. Small, irregularly arranged, secondary tubercles cover all the area outside the scrobicules. There are no distinct gill slits. Lantern supports are present on the first interambulacral plates.

REMARKs.- It is difficult to assign this genus to any family with certainty because nothing is known of its spines, pedicellariae, or peristomial plates. Having a rigid test, it cannot belong to the Miocidaridae. It is excluded from the Diplocidaridae by its uniserial pores.

Among the Cidaridae, Leurocidaris montanaro resembles Paracidaris caumonti (Cotteau) from the Middle Jurassic (Bajocian). Both species have secondary tuberculation consisting mainly of irregularly arranged granules. In L. montanaro a scrobicular ring of tubercles is absent; in $P$. caumonti it is slightly developed on some plates and absent on others according to Cotteau's figures (1875: pl. 153: figs. 9, 12; 1880: pl. 153: fig. 6). Both species have irregularly arranged tubercles on the ambulacral plates. Lambert and Thiéry (1910:135) placed this Bajocian species in Paracidaris, a genus they define as having enlarged, secondary, ambulacral tubercles adorally with an enlarged tubercle tending to cover two plates. I have not seen the holotype of $P$. caumonti, but Cotteau does not show these enlarged tubercles in his illustrations. If these enlarged tubercles are absent, then $P$. caumonti perhaps should be referred to Leurocidaris.

\section{Leurocidaris montanaro (Zardini), new combination}

Plate 12: figures 6, 7, Plate 13

Cidaris montanaro Zardini, 1973a:12, pl. 5: figs. 14, 15a,b.

MATerial.-The following description is based on many fragments and Zardini's holotype and two paratypes. The holotype $(140-\mathrm{S}-\mathrm{Z}$, in MCA) is a partially crushed fragment composed of part of two interambulacra and two ambulacra. This fragment is $8.0 \mathrm{~mm}$ wide and $4.6 \mathrm{~mm}$ high. The figured paratype is also a fragment and is composed of two complete interambulacra, one complete ambulacra, and part of two ambulacra. This specimen is 9.1 $\mathrm{mm}$ wide and $6.2 \mathrm{~mm}$ high. An unfigured paratype is the largest fragment, $10.1 \mathrm{~mm}$ wide and $5.4 \mathrm{~mm}$ high. One side of the test is crushed. Most of the test is preserved, except the apical system.

SIzE AND SHAPE.-The unfigured paratype was originally an approximate $10.0 \mathrm{~mm}$ in diameter and $5.4 \mathrm{~mm}$ high. The figured paratype was $9.3 \mathrm{~mm}$ in diameter (estimated) and $5.5 \mathrm{~mm}$ high. The holotype is too incomplete to permit an estimate of its original diameter, but it was approximately $4.6 \mathrm{~mm}$ high. The height of the test varied between 54-59 percent the diameter of the test. The test was rigid. Although the specimens are somewhat crushed, most of the slippage along the fractures is not along sutures but across plates.

Apical System.-No plates are preserved. Although none of the specimens are well enough preserved to permit measurement of the diameter of the apical system, it is apparent that it was very large, approximately 55 percent $\mathrm{D}$. On the figured paratype the adapical-most plates of two ambulacra and two interambulacra are preserved showing 
the outline of part of the apical system. Its outline was pentagonal with the apices at the ambulacra.

Ambulacka.-The ambulacra (Plate 12: figure 6; Plate 13: figure 2) are narrow, $1.25 \mathrm{~mm}$ wide at the ambitus ( 12.5 percent $D$ ) and 29 percent the width of an interambulacrum in the unfigured paratype. The figured paratype, estimated to have been $9.3 \mathrm{~mm}$ in diameter, has 38 plates in an ambulacrum with 7 plates abutting against an interambulacral plate at the ambitus. All the plates are primaries with nonconjugate pores; the outer pore (near the adradial suture) is situated more adapically than the inner. The pore-pairs are between 60-70 percent the width of the ambulacrum. Each plate bears 3 (a few with 4 or 5 ) small, equal-sized, secondary tubercles irregularly arranged between the inner pore and the perradial suture. A narrow groove is present in the perradial suture.

INTERAMBULACRA.-The interambulacra are composed of a few, large plates; 7 or 8 plates compose each interambulacrum in the two paratypes. An interambulacrum is $4.40 \mathrm{~mm}$ wide ( 44 percent $\mathrm{D}$ ) in the unfigured paratype. The plates are largest adapically except for a single, smaller plate at the margin of the apical system. This plate, unlike all the others, lacks a primary tubercle. The tubercles are prominent and are largest adapically. The largest one on the figured paratype is $0.92 \mathrm{~mm}$ in diameter. They decrease in size adorally. The mamelons are distinctly undercut. At the ambitus and adapical to it, they are perforate; but those adoral to the ambitus are imperforate. The tubercles have crenulate parapets and small, circular, shallow scrobicules lacking a scrobicular ring of tubercles. The scrobicules are not confluent but are widely separated from each other. Small, equalsized, irregularly arranged, secondary tubercles cover all the area outside the scrobicules.

The adradial margin of the interambulacral plates are serrated (Plate 13: figure 6), reflecting the curve of each adjacent ambulacral plate. The interambulacra do not bevel over the ambulacra. The suture between the two areas is nearly vertical (Plate 13: figure 7).

Peristome.-Because the tests are slightly crushed or incomplete, the diameter of the peristome is uncertain; but its width appears to have been approximately 55 percent $\mathrm{D}$. No distinct gill slits are present, although the peristomial edge of the interam- bulacra curve very slightly adapically near the ambulacra. This curving may or may not indicate the incipient development of gill slits.

LANTERN SUPPORTS.-A pronounced ridge occurs along the adoral margin of the inside of each interambulacrum (Plate 13: figure 9). Presumably this ridge was a lantern support (apophysis).

Inside of Test.-The inside of the interambulacra are slightly depressed near the middle of each plate but flush along the interradial (medial) suture (Plate 13: figure 9).

OCCURRENCE.-This species is most common at Alpe di Specie, but also occurs at Milieres and Campo.

\section{Family PSYCHOCIDARIDAE Ikeda}

\section{Levicidaris, new genus}

Type-SPecies.-Levicidaris zardinia, new species, from the Late Triassic, early Karnian, St. Cassian Beds, Italy.

The test is small and rigid with nonimbricate plates. The ambulacra are composed throughout of primary plates that bear a single secondary tubercle. The pores are not conjugate. Each interambulacral plate bears a primary, imperforate, noncrenulate tubercle. The character of peristomial plates is not known.

REMARKs.-This genus most resembles Merocidaris, previously known from the Middle and Late Jurassic. Levicidaris zardinia differs from the typespecies of Merocidaris, $M$. honorinae Cotteau, in that all its primary tubercles are imperforate and noncrenulate. In $M$. honorinae the adapical tubercles are reported by Thiéry (1928:180) to be perforate and crenulate. Through the kindness of Madam Peyré at the Laboratoire de Paléontologie, Université de Paris-Sud at Centre d'Orsay, I have been able to study one of Cotteau's paratypes of $M$. honorinae (Cotteau, 1880, pl. 258: figs. 1-4). I can confirm that the adapical tubercles are perforate and crenulate and the more adoral tubercles are imperforate and noncrenulate.

\section{Levicidaris zardinia, new species}

Plate 14, Plate 15: figures 1-5

Material.-This description is based on many fragments and four well-preserved specimens lack- 
ing only their apical systems and peristomial plates. Two of the specimens are slightly crushed. Zardini (1973a, pl. 5: figs. 28a,b; 29a,b; 33a,b) referred three of these to Cidaris admeto Braun, but they cannot belong to this species because they have imperforate tubercles.

Size AND SHAPE.-The tests vary from 10.5 to 15.3 $\mathrm{mm}$ in horizontal diameter with a height $58-60$ percent the diameter of the test (D). The test is rigid; the sutures between the interambulacra and ambulacra are nearly vertical, or with the interambulacra slightly beveling over the ambulacra.

Apical System.-No plates are preserved. The diameter of the system is $45-47$ percent $D$.

AmbULACRA.-The ambulacra are slightly sinuous and moderately wide (12-14 percent $D$ at the ambitus). The width is approximately the same from just above the ambitus to an area near the peristome. At the peristome the ambulacra are slightly widened. The plates are all primaries. The 66 plates form an ambulacrum in a specimen 10.5 $\mathrm{mm}$ in diameter; 70 , in a specimen $12.6 \mathrm{~mm}$; 76 , in a specimen $15.0 \mathrm{~mm}$; and 82 , in the holotype 15.3 $\mathrm{mm}$ in diameter. Seven or 8 ambulacral plates abut an interambulacral plate at the ambitus. The pores are not conjugate; each pore is separated by a prominent, thick, vertical ridge (Plate 14: figures 7,8 ) except adorally where this ridge is absent (Plate 15: figure 1). A lower, less-developed ridge runs along the adapical edge of each pore-pair and joins with the vertical ridge that extends between the pores of a pore-pair. The outer pore of a pore-pair (the pore nearer the adradial suture) is situated more adapically than the inner. Each plate curves adapically towards the perradial suture of the ambulacrum (the median suture). The plates bear a single, prominent, secondary tubercle between the inner pore of a pore-pair and the perradial suture. Because the plates curve apically here, these tubercles are situated slightly adapical to the pore-pairs occurring on the same plate. Throughout most of the length of the ambulacra, these tubercles abut each other along the perradial suture. Near the peristome, however, the tubercles are slightly separated; a small granule may be present in this narrow, open space along the perradial suture (Plate 15: figure 1).

INTERAMBULACRA.-Each interambulacrum is 43 45 percent $\mathrm{D}$. It is composed of 11 or 12 plates in the specimen $10.5 \mathrm{~mm}$ in diameter; 11 in the speci- men $12.6 \mathrm{~mm} ; 12$ in the specimen $15.0 \mathrm{~mm}$; and 13 in the specimen $15.3 \mathrm{~mm}$ in diameter. Each plate (except one of the most adapical plates in each interambulacrum) bears a large, imperforate, noncrenulate tubercle with a prominent mamelon, which is slightly undercut. The scrobicules are circular to slightly elongate longitudinally. Above the ambitus they are separated transversely from each other by their scrobicular rings of secondary tubercles. Both rings are complete, and a few granules are present in the narrow space between the rings. At the ambitus and just below, the scrobicules are separated by a single row of scrobicular tubercles (one row for both scrobicules). Nearing the peristome the scrobicules are confluent with no secondary tubercles between scrobicules of adjacent plates (transversely). Longitudinally, the primary tubercles of the same interambulacrum are separated by irregularly arranged, secondary tubercles. The dimensions of a plate at the ambitus of the holotype, $15.3 \mathrm{~mm}$ in diameter, are: width of plate $3.6 \mathrm{~mm}$, height $2.3 \mathrm{~mm}$, diameter of scrobicular ring $2.2 \mathrm{~mm}$, and diameter of the mamelon $1.2 \mathrm{~mm}$.

Peristome.-Diameter 47-49 percent D. On some specimens slight indentations occur at the peristome near the adradial sutures (Plate 14: figure 2). These may be gill notches.

LANTERN SUPPORTS.-The lantern supports are small consisting of only a slight thickening of the adoral-most interambulacral and ambulacral plates near the adradial suture (Plate 15: figure 5).

INS1DE OF TEST.-The interambulacral plates are thickened medially (vertically) and at the transverse suture forming on the inside of each interambulacra a vertical depression along the medial interradial suture with a ridge along the transverse sutures (Plate 15: figure 4).

Occurrence.-This species is most common at Alpe di Specie and Misurina, but fragments have been found at Boa Staolin and Tamarin.

\section{Megaporocidaris, new genus}

TYPe-SPECIES.-Megaporocidaris mariana, new species, from the Late Triassic, early Karnian, St. Cassian Beds, ltaly.

The test is small and rigid with nonimbricate plates. The ambulacra are composed of primary plates throughout their length. The pores are very 
large and are enclosed by prominent peripodia. The ambulacral plates are very high. Each interambulacral plate bears a primary, imperforate, noncrenulate tubercle with prominent mamelons. No lantern supports are present.

REMARKs.-On first impression this genus resembles Mikrocidaris whose type-species also occurs in the St. Cassian Beds. Both genera have tests with pentagonal marginal outlines, high ambulacral plates with very large pores, and interambulacra with primary tubercles having prominent mamelons. However, Megaporocidaris is easily distinguished by its imperforate tubercles and ambulacra that extend to the apical system. In Mikrocidaris the ambulacra do not reach the apical system in adults, and its tubercles are perforate.

Megaporocidaris differs from Levicidaris (whose type-species, $L$. zardinia, also occurs in the St. Cassian Beds), in its ambulacra, which have far higher plates with much larger pores.

\section{Megaporocidaris mariana, new species}

Plate 15: figures 6-8, Plate 16

Material.-This description is based on fourteen fragments and three well-preserved specimens that lack their apical systems and peristomial plates. One of the specimens was referred by Zardini (1973a: pl. 5: figs. 17a, b, c) to Mikrocidaris subpentagona (Münster). The type specimens (2728$\mathrm{S}-\mathrm{L})$ are deposited in MCA.

Size AND SHAPE.-The tests are 4.5, 7.3, and 8.9 $\mathrm{mm}$ in horizontal diameter. The smallest test has a height equal to 62 percent of the diameter of the test (D). The specimen $7.3 \mathrm{~mm}$ in diameter has a height 64 percent $D$, and the largest specimen has a height 67 percent $D$. This increase in height relative to the size of the test may be real or may result from post mortum alteration. More specimens are needed to be certain. The test was rigid. The suture between the interambulacra and ambulacra is thick (Plate 15: figures 6,7) and slightly beveled over the ambulacra without denticulations (Plate 15: figure 6). The marginal outline of the test is pentagonal with the apices in the interambulacra.

Apical System.-No plates are preserved. The diameter of the system is approximately 45 percent D. The outline of the border between the apical system and the rest of the test is pentagonal with the apices in the interambulacra (Plate 16: figure 1).

Ambulacra.-The ambulacra are straight and moderately wide, $16-18$ percent $D$ at their greatest width. The plates are all primaries: 27 or 28 plates form an ambulacrum in the specimen $4.5 \mathrm{~mm}$ in diameter; 36 , in the specimen $7.3 \mathrm{~mm}$ in diameter; and $42-44$, in the specimen $8.9 \mathrm{~mm}$ in diameter. Three plates (two whole plates and one-half the height of the others) abut an interambulacral plate at the ambitus. The plates at the apical system are higher than wide, but their height decreases adorally. At the midzone a plate in the largest specimen is $0.87 \mathrm{~mm}$ wide and $0.37 \mathrm{~mm}$ high with the height 42 percent of the width. The pore-pairs are in welldeveloped peripodia (Plate 16: figure 5). The outer pore of a pair is larger and more adapical in position than the inner. The pores are not conjugate. The peripodia occupy 54 percent of the width of a plate at the midzone. Each plate bears a secondary tubercle in the adapical corner between the inner pore and the perradial (medial) suture. Every second or third plate in a column bears a second tubercle in the adapical corner between the outer pore and the adradial suture (between the ambulacra and interambulacra).

INTERAMBULACRA.-An interambulacrum at its greatest width is 37 percent $\mathrm{D}$ and is composed of 12 plates in a specimen $4.5 \mathrm{~mm}$ in diameter; 14 or 15 in the two larger specimens $(7.3$ and $8.9 \mathrm{~mm}$ in diameter). Each plate bears a primary, noncrenulate tubercle with a very prominent, imperforate mamelon, which is slightly undercut (Plate 16: figure 2). The scrobicules are circular or wider than high. Some are confluent or are separated by a few granules in a single row along the transverse suture. A plate at the ambitus of the largest specimen, $8.9 \mathrm{~mm}$ in diameter, has the dimensions: width of plate $1.85 \mathrm{~mm}$, height of plate $1.27 \mathrm{~mm}$, diameter of the mamelon $0.90 \mathrm{~mm}$, and width of scrobicule $1.30 \mathrm{~mm}$.

Peristome.-Diameter $42-45$ percent D.

LANTERN SUPPORTS.-Several of the fragments (Plate 15: figure 6) show the adoral portion of the inside of the edge of the test, but no lantern supports are present.

INSIDE OF Test.- The inside surface of the interambulacra (Plate 15: figures 6, 8) are depressed 
at the center of each plate and slightly raised along the medial interradial suture.

Occurrence.-This species (even small fragments) is easily identified because of the very large, imperforate tubercles and the small number of ambulacral plate facets on them. However, all the specimens except one from Misurina are from Alpe di Specie. A search through thousands of fragments from the other St. Cassian localities has revealed no other specimens.

\section{Family TIARECHINIDAE Gregory}

This family has always been considered to have two genera, Tiarechinus and Lysechinus. I have studied the holotype and only known specimen of Lysechinus and cannot agree with Gregory's (1896) interpretation of this specimen. I see none of the sutures described by Gregory and do not believe that it is even an echinoid. Therefore, this family is here confined to the genus Tiarechinus.

Tiarechinus is so different from any other genus that it cannot with any certainty be referred to a suborder. Many characters are peculiar. For example, each interambulacrum has only a single plate at the peristome, while in the row directly above it are three plates. Its periproct is extremely small, but its apical system is extremely large. There is a genital pore in only two genital plates and no madreporite. Finally this genus is unusual for the Triassic in its elongate shape and in having most of its primary tubercles located on the ventral surface.

The presence of three rows of plates in the interambulacra led many workers (see Mortensen, 1935:521, for a detailed history) to consider this echinoid as a relative to the Paleozoic echinoids, which had more than two columns in each interambulacrum. Other workers, including Mortensen, followed Döderlein (1906:183) in noting the resemblance of this species to the immature of an arbacioid in which the plate arrangement is the same. They considered them as ancestral to the arbacioids. Bather (1909:257) discounted this view and considered the resemblance between the interambulacra to be mere convergence. He referred it to the cidaroids. In general I agree with Bather, but do not believe that we have sufficient evidence at this time to determine the affinities of this species.

\section{Genus Tiarechinus Neumayr}

\section{Tiarechinus princeps Neumayr}

Figure 7, Plate 17: figures I-5

Tiarechinus princeps Neumayr, 1881:169, pl. 2: figs. 4a-c.Lovén, 1883:11, 64, pl. 13: figs. 150-162.-Mortensen, 1935:519, figs. 312a-e.

This species has been described in detail by Lovén and Mortensen. Therefore, no description is included here. I have examined two well-preserved specimens collected by Rinaldo Zardini and have discovered nothing to contradict these two authors' descriptions. In particular, Lovén's superb illustrations (Figure 7) are completely accurate, as is typical of his work. The plate sutures are very clear on Zardini's specimens, particularly when viewed under xylene; and their position is exactly as shown by Lovén.

\section{Genus Lysechinus Gregory}

\section{Lysechinus incongruens Gregory}

Plate 17: figures 6-8

Lysechinus incongruens Gregory, 1896:1000, pl. 51.-Bather, 1909:66-68, 258.

Gregory based this genus and species on a poorly preserved specimen from the St. Cassian Beds. He stated that it differed from Tiarechinus princeps Neumayr in several ways. It lacked distinct primary tubercles. Its ambulacra were almost confined to the adoral side. Finally, each interambulacrum was composed of a single plate at the peristome followed by two in the second row and three in the third and fourth rows. In Tiarechinus princeps only two rows are present in each interambulacrum with one plate in the adoral row and three in the second row.

Bather (1909:66) reexamined Gregory's specimen and was unable to see the characters described by him. I have also examined it and can see none of the characters claimed by Gregory. In fact, I do not believe that it is an echinoid at all. I can see no plate sutures and no evidence that the specimen is composed of crystalline calcite. The specimen appears to be a mollusk. 


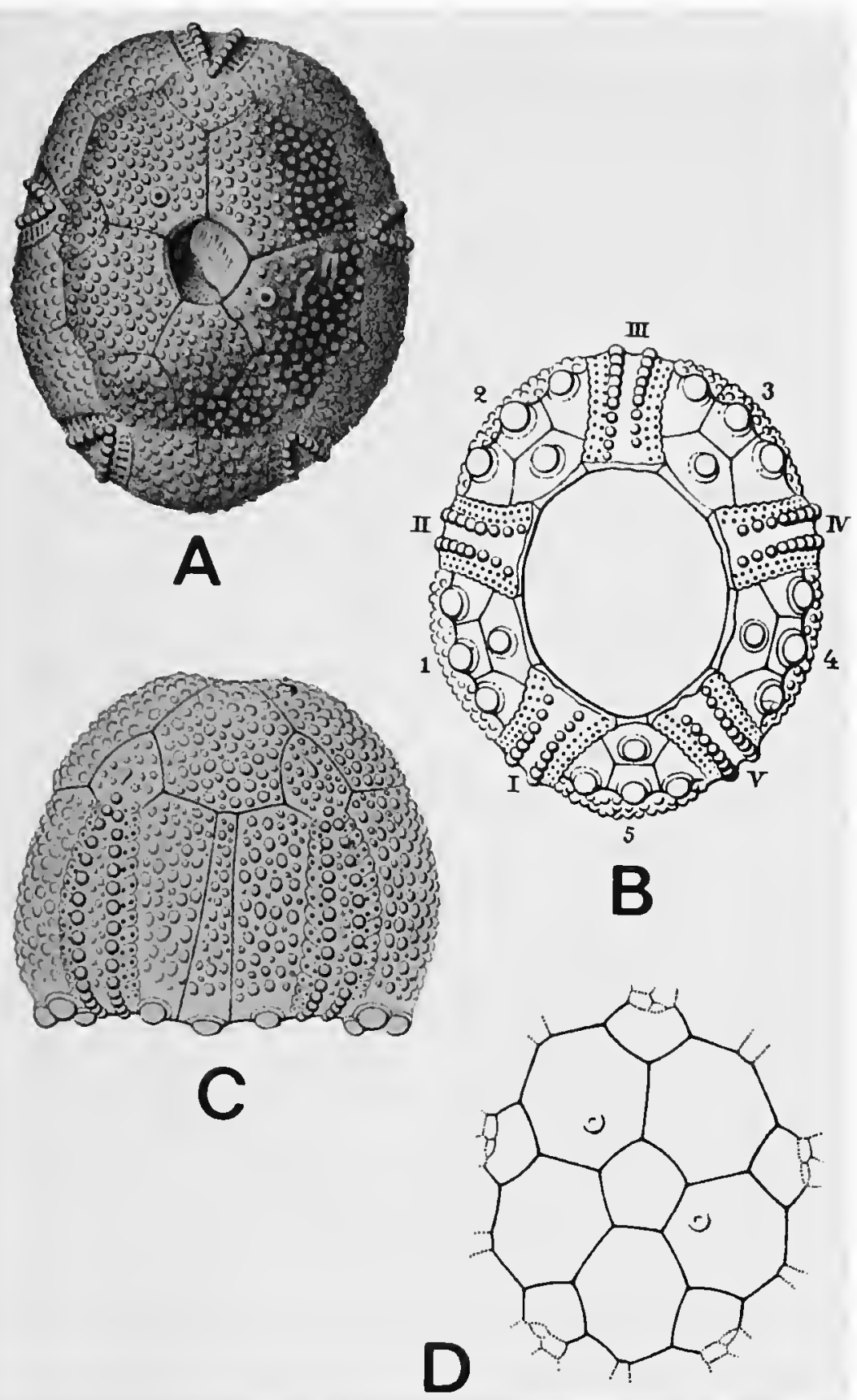

FIGURE 7.-Tiarechinus princeps Neumayr: A, adapical; B, adoral; $\mathrm{C}$, side views of specimen in GB, $\times 9$; D, apical system of same specimen. (Photocopied from Lovén, 1883, pl. 13: figs. $150,152,154,155$.

\section{Fragmental Material}

Thousands of fragments of echinoids have been collected by Mr. Zardini from the St. Cassian Beds. I have studied all of these, but unfortunately most of them cannot be identified. It is apparent that many more species were present than the twelve described here. Where possible I have described those fragments which I feel represent separate species. In this way we have a better idea as to the number of echinoid species living during St. Cassian time. However, no names are attributed to these species because not enough is known of the specific characters from all of the fragments collected. Fragments of six species are described below, and there are probably fragments of another six, which are too poorly preserved to permit description.

\section{Triadocidaris species A}

Plate 18: figures 1, 2

There are five interambulacral fragments of a large species of Triadocidaris which clearly differ from the other species of this genus known from the St. Cassian Beds. This species has a test 40-50 $\mathrm{mm}$ in horizontal diameter; perforate, noncrenulate tubercles; large extrascrobicular spaces covered with secondary tubercles; and denticulations on the inside of the adradial margin of the interambulacra where they bevel over the ambulacra. In size this species resembles Triadocidaris subsimilis (Münster) and $T$. giauensis (Zardini), but it differs from both of them in having far wider extrascrobicular areas.

Occurrence.-Alpe di Specie.

\section{Triadocidaris species $\mathbf{B}$}

Plate 18: figures 3-5

This species appears to have a low test. The fragments of the interambulacra are wide and curve sharply inward below the ambitus. There are 10 plates in each interambulacra in the smaller specimens and up to 20 in the larger. The tubercles are perforate, noncrenulate, and the scrobicules are confluent adorally. The interradial tract is wide with many secondary tubercles. The interambulacra are denticulate and strongly bevel over the ambulacra.

Although no ambulacra are preserved in any of the specimens, it is possible to know the number of ambulacral plates abutting each interambulacral plate by counting the number of denticulations on the inside of the interambulacral plates. A specimen with an interambulacrum $4.1 \mathrm{~mm}$ high has five ambulacral plates abutting an interambulacral plate at the ambitus; a specimen with an interambulacrum estimated to be $7.5 \mathrm{~mm}$ high has seven.

The lantern supports are formed by thickening of the interambulacra (and probably ambulacra) near the adradial suture. 
Comparison with Other Species.-This species differs from Triadocidaris venusta in having wider interradial tract, less-elevated bosses, and lower interambulacral plates. It differs from $T$. suessii (Laube) in having shallower and less oblique scrobicules, and less clearly demarcated interradial tracts. It is easily distinguished from Triadocidaris subsimilis (Münster) by its smaller test with wider interradial tract, and far fewer interambulacral plates. Finally this species differs from $T$. giauensis in having more interambulacral plates and more confluent scrobicules.

Occurrence.-Campo, Alpe di Specie, Milieres, and Forcella Giau.

\section{Species with Crenulate Tubercles}

\section{Species 1}

Plate 18: figures 6-8, Plate 19: figures 1,2

There are six fragments of interambulacra that appear to belong to the same species. The echinoid was a large species having perforate, crenulate tubercles with sharply delineated bosses, and basal terraces, deep transversely elongated scrobicules confluent or separated along their transverse sutures by a single row of small nodes. A wide medial tract covered with nodes is present along the interradial suture. The interambulacra bevel over the ambulacra as is indicated by the presence of denticulations along the adradial margin on the inside of the plates (Plate 18: figure 7). On the inside of the test the interambulacral plates are depressed at the tubercles. The adoral area of interambulacra at the edge of the peristome is visible on two of the specimens, but no lantern supports are present on them.

This species is easily distinguished from the three species having crenulate tubercles known from the St. Cassian Beds. It differs from Paurocidaris rinbianchi (Zardini) by having a far larger test, lower, more numerous interambulacral plates with a wider medial tract of secondary tubercles. It differs from Leurocidaris montanaro (Zardini) in not having its extrascrobicular areas covered with uniform-sized secondary tubercles, and from Polycidaris regularis (Münster) in having less transversely elongated scrobicules. Zardini (1973a:9) referred fragments similar to some of these to
Miocidaris ampczzana Zardini but one of his specimens (1973a, pl. 6: fig. 26b) has large lantern supports which are absent on these fragments (Plate 19: figure 2).

OCGURRENCE.-Campo.

\section{Species 2}

Plate 19: Figure 3

One fragment comprising most of an interambulacrum is easily differentiated from the three described species having crenulate tubercles and species 1 . The fragment is comprised of 13 interambulacral plates extending from the peristomial border to somewhere above the ambitus. The test was approximately $15 \mathrm{~mm}$ high. The tubercles are perforate and crenulate, with strongly elevated bosses lacking basal terraces. The scrobicules are confluent and are transversely elongated, with this elongation more pronounced adorally. The interambulacra bevel over the ambulacra as indicated by the denticulations along the adradial margin on the inside of the plates. No lantern supports are present on the adoral edge of the interambulacrum.

This species differs from Paurocidaris rinbianchi (Zardini) by having a higher test, and lower, more numerous interambulacral plates. It differs from Leurocidaris montanaro (Zardini) in not having its extrascrobicular areas covered with secondary tubercles of uniform size. It more closely resembles Polycidaris regularis (Münster) with its transversely elongated scrobicules, but differs in having far narrower interambulacra with a narrower medial zone along the interradial suture. Finally, it differs from species 1 in having lower plates and more strongly elevated bosses lacking basal terraces.

OcCURRENCE.-Rumerlo.

\section{Species 3}

Plate. 19: figures 4, 5

Several fragments of interambulacra are easily distinguished from all the other St. Cassian echinoids with crenulate tubercles by the presence of more than one large tubercle on each plate. One of these fragments (Plate 19: figures 4,5) is composed of six plates of the adoral portion of an interambulacrum. Each plate bears one larger tubercle with perforate mamelon, crenulate parapet, 
strongly elevated boss, and nonconfluent scrobicule. Although the medial area along the interradial suture is covered with secondary tubercles, the area between the primary tubercle and the adradial suture is occupied by two tubercles similar to, but smaller than, the primary. The interambulacra bevel over the ambulacra evidenced by the denticulations along the adradial margin on the inside of the plates (Plate 19: figure 5).

Zardini (1973a:11, pl. 5: fig. 13) refers a fragment very similar to these to Cidaris leonardi Zardini.

Occurrence.-Campo, Tamarin, and Forcella Giau.

\section{Mesodiadema? Fragments}

Plate 19: figuris 6-9, Plate 20: figurfis 1-5

There are many interambulacral plates that are indistinguishable from Bather's (1909:117-123, pl. 8: figs. 192-211) specimens of Mesodiadema margaritatum and $M$. latum from the Triassic of Bakony. The plates are very wide, generally have their primary tubercles nearer the adradial margin, and have small secondary tubercles scattered over the extrascrobicular surfaces. The primary tubercles are perforate, noncrenulate, with well-developed mamelons, sharp parapets, steeply sloping bosses, and deep, well-delineated scrobicules. Some of the plates have confluent scrobicules; in others they are separate. The plates strongly imbricate along the adradial suture where denticulations are present and along the interradial sutures where the plates are beveled. All the plates are isolated except near the peristome (Plate 19: figures 6, 9; Plate 20: figure 1), where some specimens have the plates still intact, held together by well-developed interambulacral lantern supports (Plate 19: figure 7; Plate 20: figure 2).

Because most of the plates are isolated, it is impossible to know how many species are represented by these fragments; but there is more than one. Sorne of the fragments near the peristome that are still intact have very low plates (Plate 19: figure 6); whereas, others which presumably represent another species have higher plates (Plate 20: figure 1).

Bather's (1909) specimen may represent only one species. The fragments he referred to $M$. margaritatum are located near the peristome. Fragments of
M. latum are isolated, and their differences with $M$. margaritatum may be due to a different location on the test.

Several of the fragments have crenulate tubercles (Plate 20: figure 5) indicating that a third species must be present.

With no information on the nature of the ambulacra in this species, it is impossible to know the familial or even ordinal position of these echinoids. Bather referred his plates to Mesodiadema, a pedinoid, because of the position of the tubercles near the adradial suture, the restriction of other ornament to fine, close-set miliaries, and the great width of the plates. However, he noted (1909:121) that the denticulations along the adradial sutures and the interambulacral lantern supports were primitive features found in Triadocidaris. $\mathrm{He}$ concluded that these plates belonged to an echinoid intermediate between Triadocidaris and later species of Mesodiadema.

The fact that these plates strongly imbricate along their transverse sutures suggests affinities with the diadematoids and the echinothurioids which have similar imbrication. Furthermore, JesionekSzymańska (1967, 1968) has described very similar imbrication in the interambulacral plates of many primitive irregular echinoids.

OccurRences.-Fragments are most common at Alpe di Specie; but a few specimens come from Campo, Milieres, Tamarin, Rumerlo, and Misurina.

\section{MoRPhological SPECimens}

There are hundreds of fragments of ambulacra. Although they cannot be specifically identified, they do show features of interest. Most of the ambulacra have wide sections along their adradial margins that bevel under the adjacent interambulacra (Plate 20: figures 6, 8, 9). Most of these tracts have grooves along their sutures that correspond to denticulations on the inside of the interambulacral plates. Incipient compounding is present on many of the specimens with every other ambulacral plate enlarged at the perradial suture (Plate 20: figures $7,8,9,12)$. In a few specimens two reduced plates are present between the enlarged plates. In two specimens several of the ambulacral plates are demiplates, not touching the perradial suture (Plate 20: figure 12). 
Auricles are present on many of the ambulacra. These auricles (Plate 20: figures 10, 11, 13) are formed by the thickening of four or five of the adoralmost ambulacral plates.
Many lantern fragments including teeth have been collected by Mr. Zardini, but all the teeth are grooved; none are keeled.

\section{SPEGIES NOT FROM THE ST. CASSIAN BEDS}

\section{Order CIDAROIDA Claus}

Family MIOCIDARIDAE Durham and Melville

\section{Genus Triadocidaris Döderlein}

\section{Triadocidaris persimilis Bather}

FigURE 8

Triadocidaris persimilis Bather, 1909:70, pl. 6: figs. 129-134.

Although this species is based on fragments, enough morphological information is available to permit generic identification. Bather's description is so thorough that no further additions can be made. This species was collected from beds of St. Cassian age in Bakony. The type specimens are in the British Museum (Natural History).

\section{Triadocidaris immunita Bather}

Figure 9

Triadocidaris immunita Bather, 1909:79, pl. 6: figs. 141-149.

These fragments are so thoroughly described by Bather that no further description is necessary. This species was collected in Raiblian beds in Bakony. The type specimens are in the British Museum (Natural History).

\section{Genus Dicyclocidaris Fell}

\section{Dicyclocidaris denticulata Fell}

$$
\text { Plate 21: figures 1-4 }
$$

Dicyclocidaris denticulata Fell, 1950:83, figs. 1-3; 1966a:U321, figs. 239 (2a, b, c).

Although based on only fragments of the interambulacra, this species is clearly a miocidarid as shown by its imbricating plates and denticulations
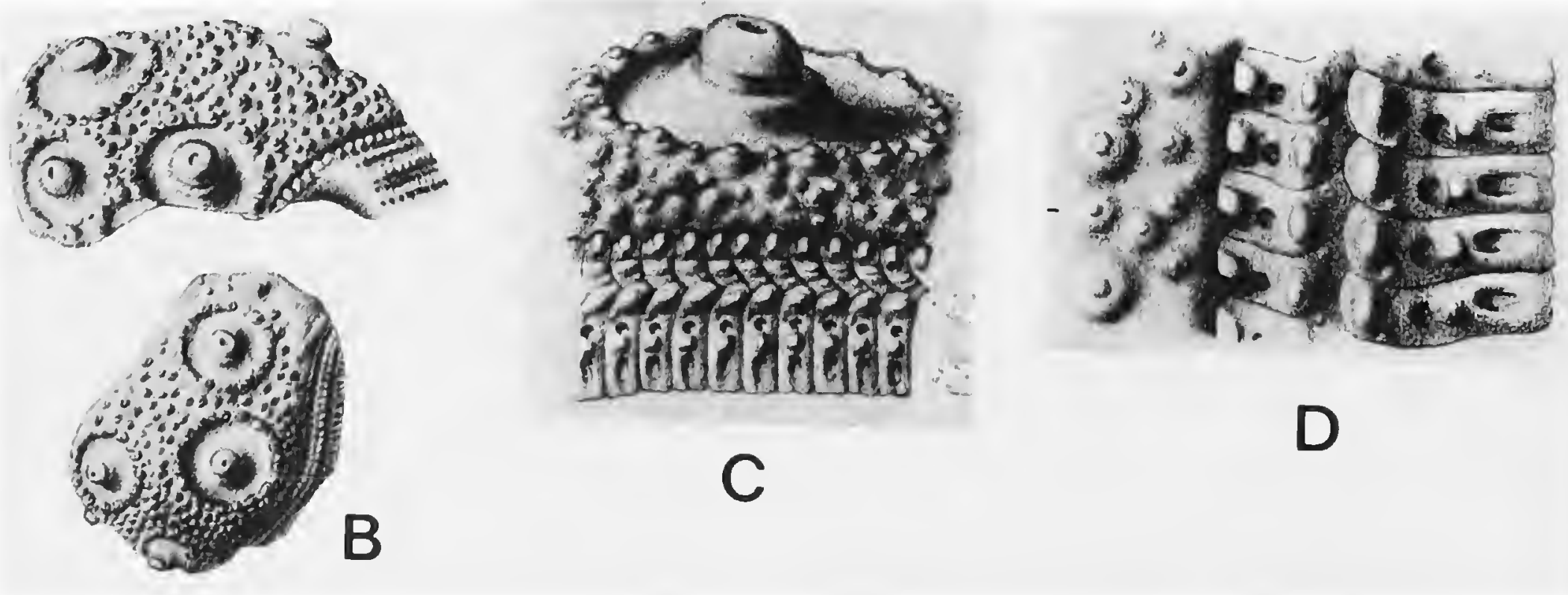

Figure 8.-Triadocidaris persimilis Bather: A, adoral view of holotype, $\times 5$; $B$, side view of same specimen, $\times 3$; $C, D$, part of ambulacrum of holotype showing the relation of the ambulacral plates to the denticles of the interambulacral plate under which they bevel, $\times 10, \times 20$. (Photocopied from Bather, 1909. pl. 6: figs. 131-134.) 


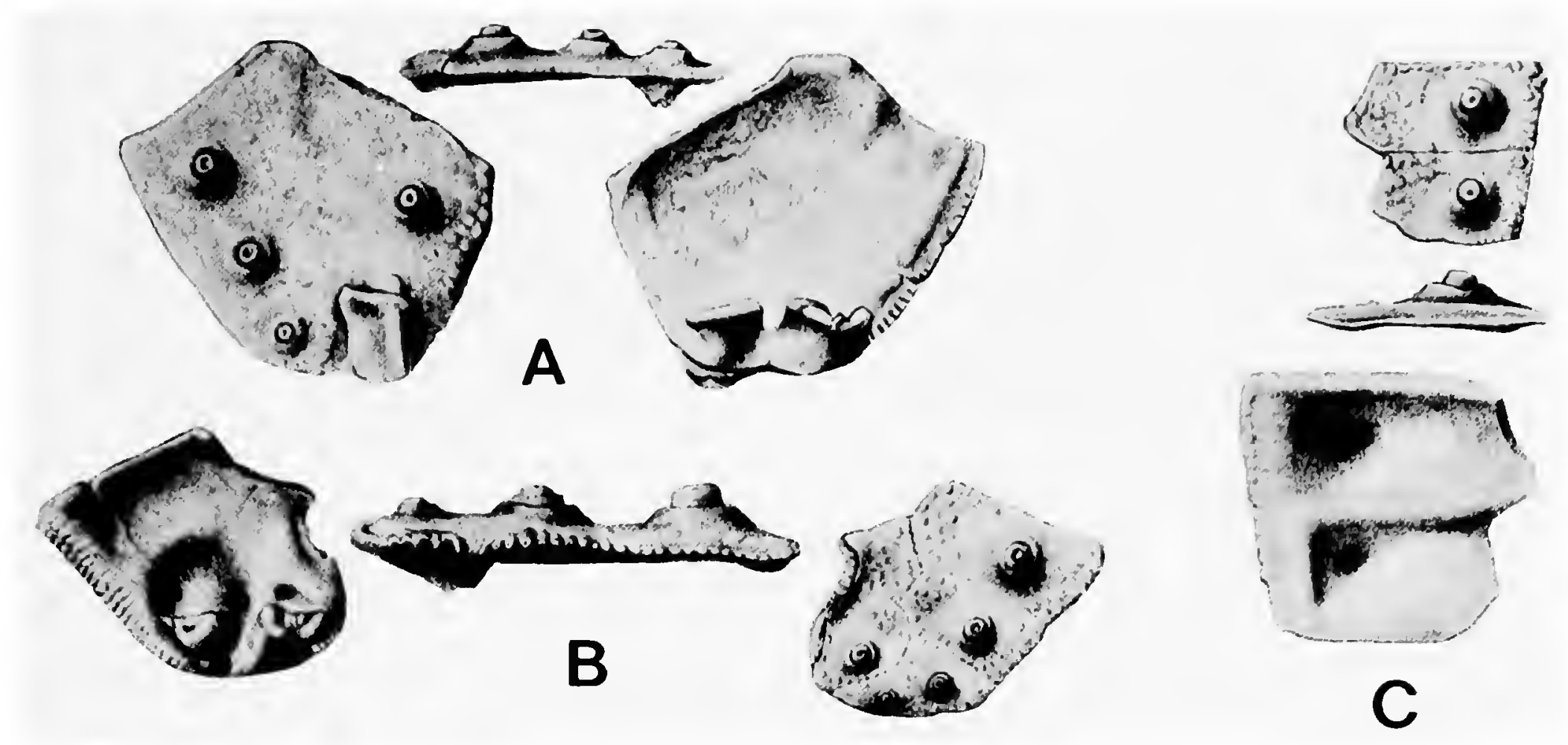

Figure 9.-Triadocidaris immunita Bather: $A$, exterior, side, and interior views of the holotype, $X 3 ; \mathrm{B}$, interior, side, and exterior views of a figured paratype showing the lantern supports and denticles, $\times 3$; c, exterior view of a figured paratype, side, and interior views, $\times 3, \times 5$, $X$ 5. (Photocopied from Bather, 1909, pl. 6: figs. 141-149.)

on the interior margin of the interambulacra where they bevel over the ambulacra. It is distinguished from the other genera of this family by its double ring of scrobicular tubercles. Through the kindness of Ian Speden of the New Zealand Geological Survey, I was able to borrow the type specimens and include here new photographs of latex pulls of these specimens.

Fell (1966a:U321) states that the spines are thorny. I have seen no thorns on any of the fragments of spines associated with the specimens. Portions of two spines are preserved (Plate 21: figure 1) and both are longitudinally striated suggesting that a cortex layer was absent.

Occurrence.-The species is known from the Karnian of New Zealand.

\section{Order PEDINOIDA Mortensen}

\section{Family PEDINIDAE Pomel}

Genus Hemipedina Wright

\section{Hemipedina? incipiens Bather}

FIGURE 10

Hemipedina (Diademopsis) incipiens Bather, 1909:124, pl. 9: figs. 212, 213.
This species is based on a fragment from the Raiblian of Bakony. The holotype is in the British Museum (Natural History). Bather placed this species in the Diadematidae (what we would now consider to be the Pedinidae) because of its wide interambulacrum, relatively small primary tubercles, and large, serially arranged secondary tubercles. However, he noted its more primitive characters, such as denticles on the interambulacral plates and interambulacral lantern supports, and stated (1909:125): "This renders the species of much interest, for it is just such a form as we might expect to find at this horizon, on the hypothesis of the independent evolution of Diademopsis from a Cidarid like Triadocidaris."

This present study confirms Bather's position that this fragment is intermediate between the cidaroids and the pedinoids and that such a transitional form would be expected to occur during the Raiblian. The earliest certain noncidaroid is the pedinoid Hemipedina hudsoni, new species, from the Norian. It is clearly a pedinoid and is more advanced than Bather's Raiblian fragment because of its ambulacral lantern supports and lack of denticles on its interambulacral plates. 


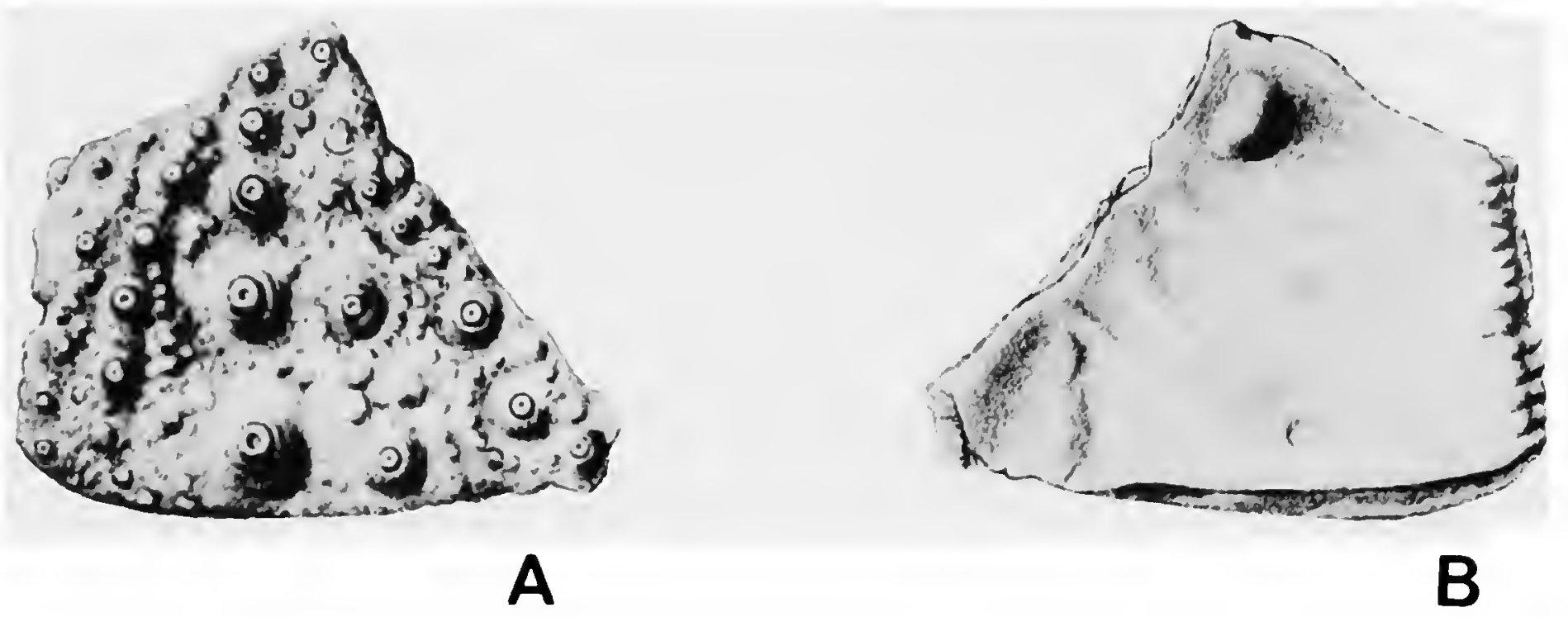

Figure 10.-Hemipedina incipiens? Bather: a, B, exterior and interior views of the holotype, $\times$ 5. (Photocopied from Bather, 1909, pl. 9: figs. 212, 213.)

\section{Late Triassic: Norian}

\section{Order PEDINOIDA Mortensen}

\section{Family PEDINIDAE Pomel}

\section{Genus Hemipedina Wright}

\section{Hemipedina hudsoni, new species}

Figure 11, Plate 21: figures 5-9

MATER1AL.-The specimen is very poorly preserved because of severe weathering. Approximately one-third of the test is absent. It is in the British Museum (Natural History), holotype, E-76154.

Shape and Size.-The specimen is slightly distorted and is $9.3 \mathrm{~mm}$ in horizontal diameter at its greatest width, $8.3 \mathrm{~mm}$ at its least, and $4.8 \mathrm{~mm}$ high. Although it is a small specimen, it is probably a mature individual considering the presence of genital pores. The test has gently sloping sides with a low ambitus and appears to have been rigid.

Apical System.-The diameter of the apical system is approximately $3.3 \mathrm{~mm}$ or 33 percent the horizontal diameter of the test. Four ocular and three genital plates are preserved. The oculars are widely exsert and pentagonal. The genital plates are large, and each has a genital pore situated near the interambulacral margin of the plate. The periproct is small in diameter, approximately one-third the diameter of the apical system.
Ambulacra.-The ambulacra are straight and wide, with a width at the ambitus of $1.8 \mathrm{~mm}$, or 50 percent the width of the interambulacra. The pore series are straight except near the peristome where they are in slight arcs of three pore-pairs each. The pore-pairs are surrounded by welldeveloped peripodia (Plate 21: figure 8). Each ambulacrum has approximately 45 plates. All are simple except for one or two occluded plates present on the peristomial margin. Between the ambitus and the peristome, a large primary tubercle covers three plates. Approximately four of these tubercles are present in each half-ambulacrum. Every third plate above the ambitus appears (Figure 11) to have an enlarged secondary or smaller primary tubercle. This tubercle seems confined to one plate and does not extend over adjacent plates. Due to the poor preservation of the specimen, the tuberculation is not preserved on many of the plates. One cannot be certain that these enlarged tubercles are present on every third plate.

INTERAMBULACRA.- Each interambulacrum is approximately $3.6 \mathrm{~mm}$ wide at the ambitus. The interambulacral plates are large with approximately 10 plates in each area. Each plate bears one or two irregularly arranged tubercles and a few, irregularly arranged nodes. The tubercles are not well enough preserved to determine whether they were perforate.

Pfristome.-The area around the peristome is 

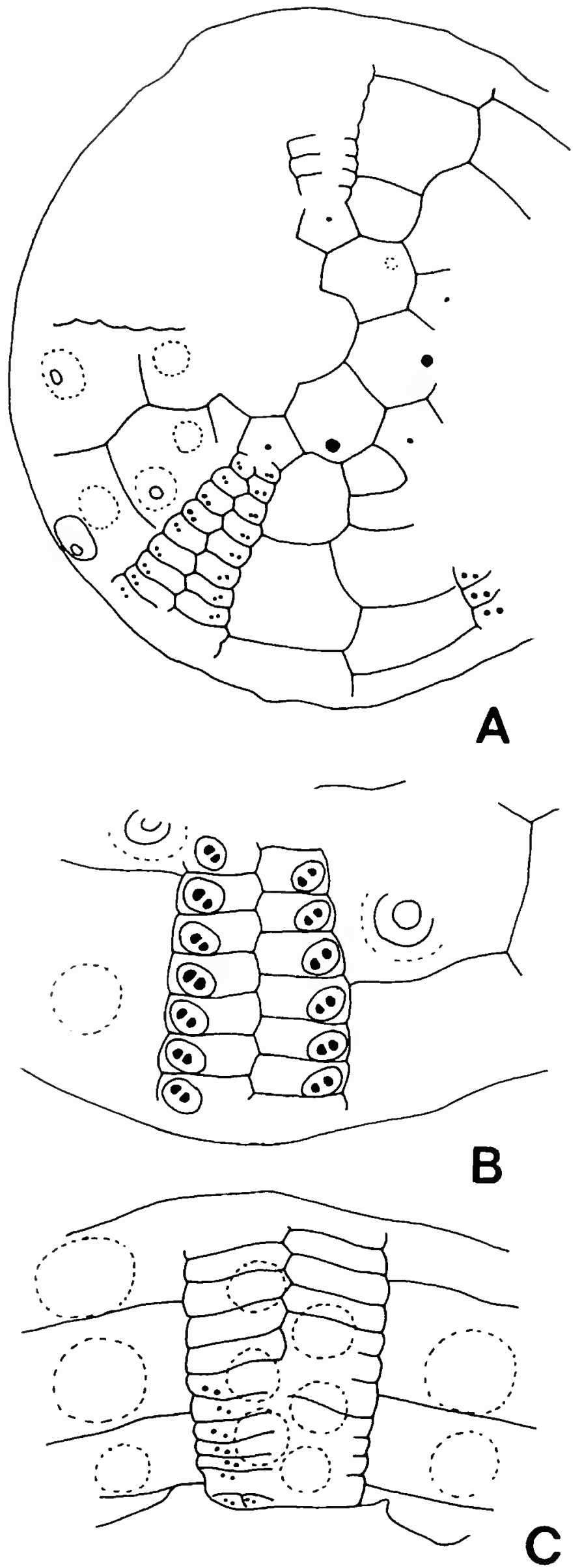

FIGURE 11.-Hemipedina hudsoni, new species: A, adapical view, $X 10 ; \mathrm{B}$, view of ambulacrum at ambitus and adapical to ambitus, $\times 15 ; \mathrm{c}$, view of ambulacrum at peristome showing the compounding of the plates, $\times 15$. (See Plate 21: figures 5-9 for photographs of holotype.) very poorly preserved, but the diameter of the peristome is approximately $5.5 \mathrm{~mm}$ or 60 percent the diameter of the test. The nature of the gill slits is not known.

LANTERN SUPPORTS.-Dr. Richard Jefferies at the British Museum (Natural History) expertly excavated the auricles on this specimen. They are well developed (Plate 21: figure 9) and separate and tilt towards each other.

Occurrence.-Late Triassic, Norian, Elphinstone Group, probably Sumra Formation (pers. comm., R. Jefferies, 1973), Wadi Milaha, Trucial Coast, Arabia. For a description of the stratigraphy and fauna, see Hudson and Jefferies (1961).

REMARKs.-This species with its compound, diadematoid ambulacral plates, ambulacral lantern supports, and small tuberculation is clearly a noncidaroid and could be either a diadematoid or pedinoid. Unfortunately, no spines are preserved, so it is not known whether they were solid, the only character that clearly separates these two orders. The test in this species appears to have been rigid, however, a character more common in the pedinoids. Furthermore, among all the genera of both orders this species most resembles species of the pedinoid Hemipedina. No certain Triassic species of Hemipedina are known, but this species resembles the Early Jurassic type-species of the genus, H. etheridgei (Wright). Its ambulacral plates are simple except adorally where a primary tubercle covers three plates. It has large genital plates with widely exsert ocular plates and large, high interambulacral plates. Hemipedina jefferiesi differs from this species and all other species of Hemipedina in having more than one large tubercle on some of its interambulacral plates.

This species resembles in general appearance some species of Diademopsis but differs from all of them in having larger, higher interambulacral plates, the only character that apparently distinguishes Diademopsis from Hemipedina. Although Lambert and Thiéry (1910:198; 1925:566) refer four Triassic (Rhaetian) species to this genus, two of these, D. heeri (Merian) and D. michelini (Cotteau) are Early Jurassic (Hettangian). The third, D. micropora (Agassiz) may also be Early Jurassic. I have tried to obtain specimens of this species; but the type specimen, which was formerly at Dijon, France, is now lost. Stoppani (1860-1865:98) de- 
scribed a species, Hypodiadema desori from the Late Triassic (Rhaetian), which Lambert and Thiéry (1925:566) refer to Diademopsis. This spe- cies is based on a fragment that, unfortunately, has been lost. Too little is known of this specimen to permit certain generic identification.

\section{Late Triassic: Rhaetian}

\section{Order CIDAROIDA Claus}

Family CIDARIDAE Gray

Genus Paracidaris Pomel

Paracidaris toucasi (Cotteau)

FIGURF 12

Cidaris toucasi Cotteau, 1875:12, pl. 143: figs. $1-4$.

This species is based on a beautiful specimen that, unfortunately, appears to be lost. The speci-

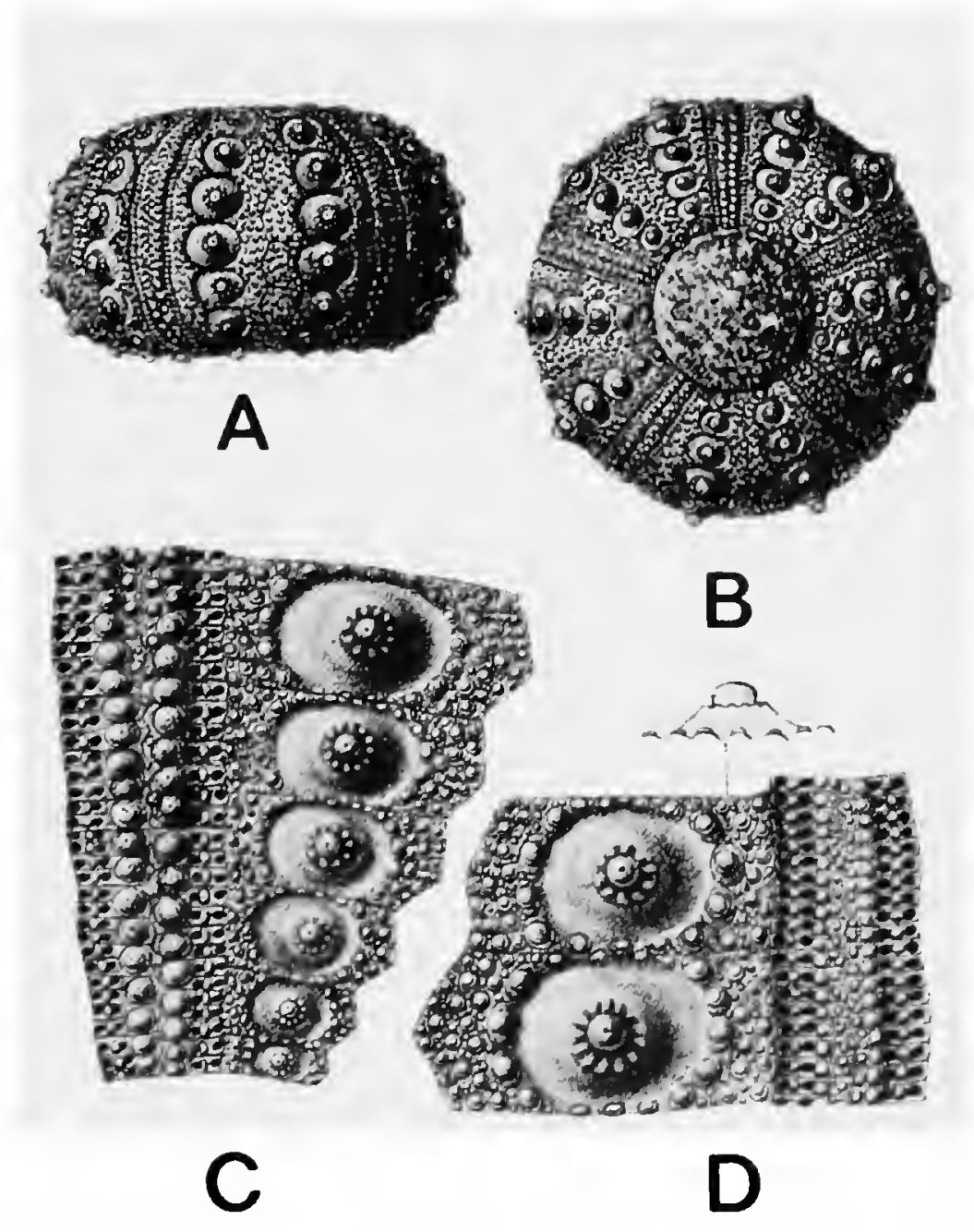

Ficure 12.-Paracidaris toucasi (Cotteau), holotype: A, side view, $\times 1$; B, adapical view, $\times 1$; c, enlarged view of adoral portion, magnification not known; $D$, portion at ambitus, magnification not known. (Photocopied from Cotteau, 1875, pl. 143. figs. 1-4.) men was in the Toucas Collection according to Cotteau. This collection, according to Dr. Jean Roman (pers. comm., 1974) is now part of the collection of the Sorbonne. However, Dr. D. Pajaud at the Laboratoire de Paléontologie des Invertébrés, Université de Paris, has been unable to locate the specimen.

\section{Paracidaris jeanneti Lambert}

FIGURE 13

Paracidaris jeanneti Lambert, 1924:448, figs. 1-2.

Lambert states that the holotype of this species is in the collections of the Institut de Géologie, Université de Neuchâtel, Switzerland. Unfortunately, according to Dr. Jurgen Remane of this institution, this specimen cannot be located.

Occurrence.-Late Triassic, Rhaetian, Bachalp, Stockhorn, Switzerland.

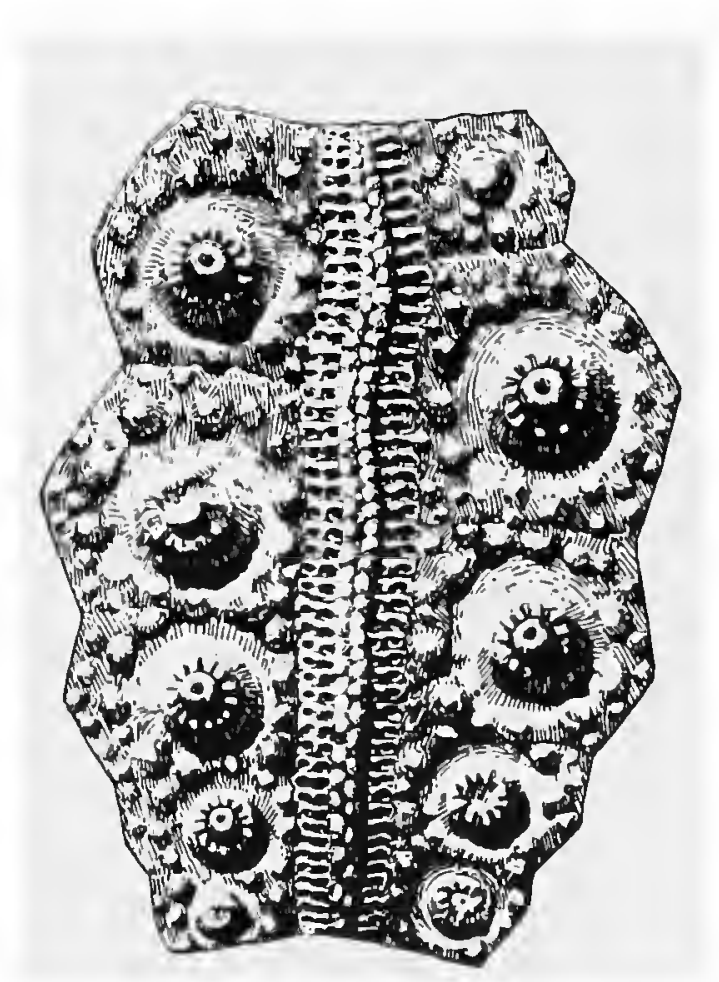

Figurf 13.-Paracidaris jeanneti Lambert, side view of the holotype. $\times$ 2. (Photocopied from Lambert, 1924, fig. 2.) 
Order PEDINOIDA Mortensen

Family PEDINIDAE Pomel

Genus Diademopsis Desor

Diademopsis? desori (Stoppani)

Figure 14

Hypodiadema desori Stoppani, 1860-1865:98, pl. 20: figs. 3-5.

Diademopsis desori (Stoppani).-Lambert and Thiéry. 1925:566.

Specimens of this species have not been studied since Stoppani described it. I tried to locate his type specimens, but according to Dr. Giovanni Pinna, assistant director of the Museo Civico di Storia Naturale in Milan, all his specimens were lost when the museum was destroyed by bombs in 1943.

From a study of Stoppani's figures, this species is a noncidaroid and probably a pedinoid. Without more knowledge of the species, it is impossible to be certain. Since it has enlarged tubercles on some of the adapical ambulacral plates, this species may be a Diademopsis as proposed by Lambert, and Thiéry.
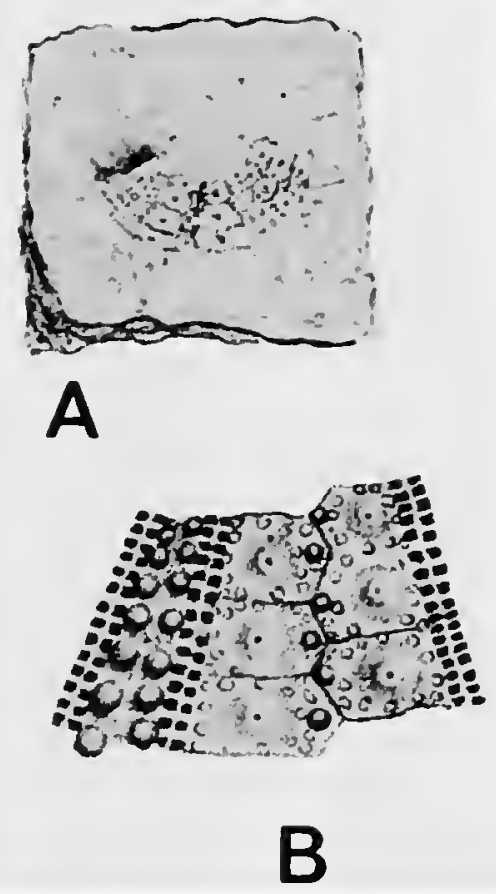
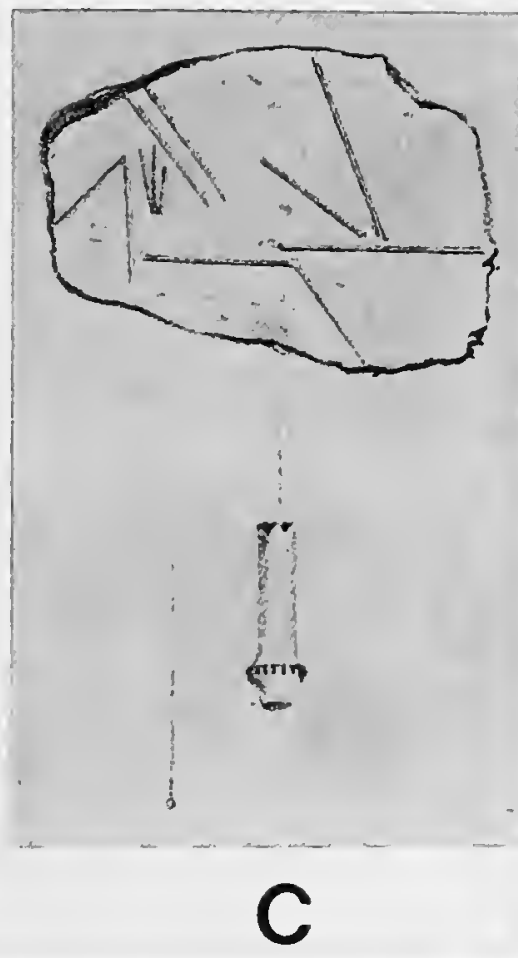

Frgure 14.-Diademopsis? desori (Stoppani), holotype: A, view of whole test; B, enlarged view of portion of holotype; $\mathbf{c}$, views of spines. (Photocopied from Stoppani, 1860-1865, pl. 20: figs. 3-5: no magnifications given.)

\section{Order HEMICIDAROIDA Beurlen}

\section{Family PSEUdodiadematTdAe Pomel}

\author{
Genus Pseudodiadema Desor
}

\section{Pseudodiadema silbinense Stefanini}

FIGURE 15

Pseudodiadema silbinense Stefanini, 1923 [1924]:51-55, pl. 5: figs. 1, 2.-Lambert and Thiéry, 1925:563 [wrongly attributed to Gregory].--Mortensen, 1935:432, 433, fig. 240d.

This is a most important species for it is the only Triassic echinoid that with some certainty belongs to the superorder Echinacea. I have been unable to locate either of Stefanini's specimens, so it has not been possible to reexamine his material. Dr. E. Montanaro Gallitelli (pers. comm., 1974) of the Istituto di Paleontologia, Università di Modena, Modena, Italy, very kindly tried to locate the specimens. Stefanini at the time of the publication of this species lived in Florence. Dr. Gallitelli contacted Dr. Berzi, curator of the Paleontological Museum in Florence. The type could neither be found there, nor at Pisa where Stefanini went before he died in 1938. Fortunately, Stefanini's description and illustrations are very adequate.

Because so many supposed Rhaetian echinoids have turned out to be Early Jurassic, I wrote to Dr. Norman Silberling to ask whether he believed that the beds Stefanini referred to were still considered Rhaetian. He directed me to Dr. Riccardo Assereto of the Istituto di Geologia, Università di Milano, Italy. He reports (pers. comm., 1974) that the Selvena outcrop (where Stefanini's specimens were collected) is considered to be Late Triassic in the new geological map of Italy. According to Dr. Assereto it is very improbable that this outcrop could be Liassic, because the overlying Calcare Massiccio contains basal Liassic faunas.

Although no teeth are known in this species, it is very likely that they were keeled. This species is the oldest echinoid known in which keeled teeth were probably present. The species belongs to the superorder Echinacea in which teeth are typically keeled. All other morphological char- 
acters of this echinoid's test link it to a family whose later Jurassic species had keeled teeth. It is possible that $P$. silbinense had these other characters but lacked keeled teeth and that the keeled teeth evolved later. Although the earliest keeled tooth is found in Middle Jurassic Bathonian species, Acrosalenia pustulata Forbes and Hemicidaris luciensis (Cotteau), the orders Salenioida, Hemicidaroida, and Phymosomatoida are assumed to have had keeled teeth. All of these orders extend back to the Early Jurassic (Hettangian). No keeled teeth have been found before the Middle Jurassic probably because lanterns are so rare in the few echinoids known from the Early Jurassic and Late Triassic. I have been able to find in the literature and in the collections of western Europe less than 15 Triassic and Jurassic echinoid species with their lanterns preserved.

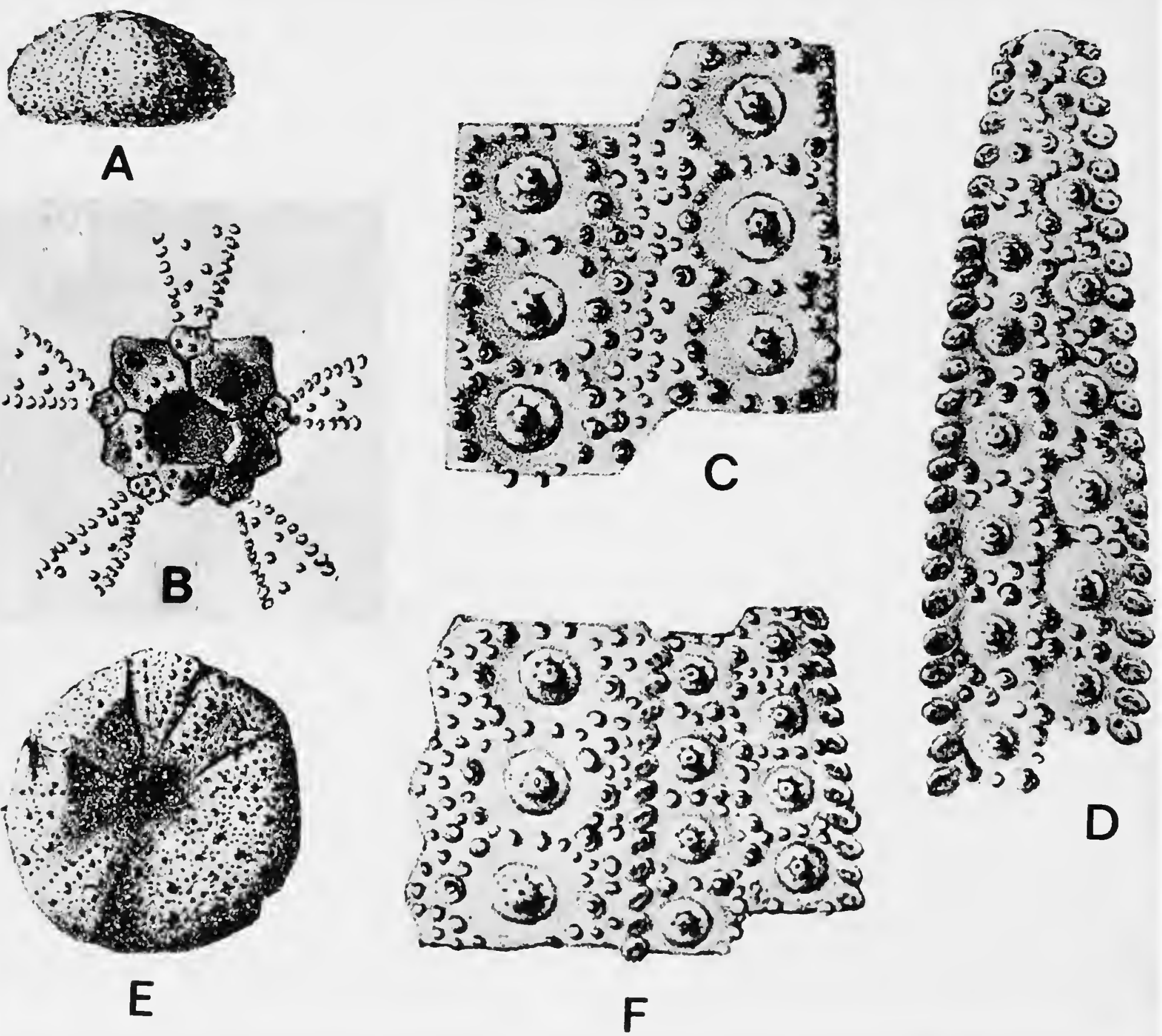

FIGURE 15.-Pseudodiadema silbinense Stefanini: A, side view of lectotype (herein designated), $\times 3$; B, apical system; C, portion of interambulacrum; D, ambulacrum of lectotype; E, adoral view of the paralectotype, $\times 3 ; \mathrm{F}$, adapical portion of the paralectotype. (Photocopied from Stefanini, 1924, pl. 5: figs. 1, 2; magnifications of B, C, D, F not known.) 


\section{Genera Incertae Sedis}

\section{Species Based on Spines}

Cidaris aculeata Leonardi and Lovo, 1950:10, pl. 1: fig. 8; early Karnian.

Cidaris aculeala Zardini, 1973a:21, pl. 12: figs. 24-35; early Karnian. Name preoccupied by Leonardi and Lovo, 1950. Zardini proposes here a new name for this species: Cidaris aialensis Zardini.

Cidaris alpina Zardini, 1973a:20, pl. 7: figs. 27, 28a-c, pl. 21: fig. 3; early Karnian.

Cidaris alternata Stoppani, 1857:413; Rhaetian.

Cidaris austriaca Desor, 1858:20, pl. 2: fig. 14; Karnian.

Cidaris avena Desor, 1855:21, pl. 2: fig. 25; Karnian.

Cidaris biconica Zardini, 1973a:18, pl. 9: figs. la-9b, pl. 21: fig. 5; early Karnian.

Cidaris biformis Münster, in Wissmann and Münster, 1841: 43, pl. 3: fig. 13; early Karnian.

Cidaris braunii Desor, in Agassiz and Desor, 1846:335; Karnian; for C. catenifera Münster non Agassiz.

Cidaris buchii Münster, in Goldfuss, 1826:121, pl. 40: figs. 5a,b; early Karnian. Bather (1909:94) selected this as the type-species for Anaulocidaris Zittel (1879:486). However, Bather's material and the other specimens referred to this genus (see p. 8 herein) consist of only isolated plates and spines.

Cidaris caudex Stoppani, 1860-1965:96, pl. 19: fig. 18; Rhaetian.

Cidaris cingulata Münster, in Wissmann and Münster, 1841: 44, pl. 3: fig. 17; early Karnian.

Cidaris coralliophila Zardini, 1973a:23, pl. 18: figs. 26-27; early Karnian.

Cidaris costalarensis Zardini, 1973a:21, pl. 12: figs. 4-1lc; early Karnian.

Cidaris costata Zardini, 1973a:19-20, pl. 10: figs. 15a-b, 20a-b; early Karnian.

Cidaris costeanensis Zardini, 1973a:2l-22, pl. 10: figs. 24a-b, pl. 17: figs. 22, 23a-b, pl. 18: fig. 37; early Karnian.

Cidaris decorata Münster, in Wissmann and Münster, 1841:45, pl. 3. figs. 22a-c; early Karnian.

Cidaris decoratissima Wöhrmann, 1889:196, pl. 5: fig. 20; Karnian.

Cidaris dorsata Münster, in Wissmann and Münster, 1841:46 47, pl. 4: figs. la-f; early Karnian.

Cidaris ecki Assmann, 1926:517-518, pl. 9: figs. 7-10; Middle Triassic.

Cidaris forminensis Zardini, 1973a:18, pl. 9: figs. 13a-b, pl. 17: figs. 9a-c, pl. 20: figs. 35a-b, pl. 21: fig. 8; early Karnian.

Cidaris fustis Laube, 1865a:290, pl. 10: figs. 4, 4a; early Karnian.

Cidaris glabra Zardini, 1973a:23, pl. 12: figs. 37-39, pl. 18: fig. 33; early Karnian.

Cidaris hausmanni Wissmann, in Wissmann and Münster, 1841:44, pl. 3: figs. 14a-d; early Karnian. Lambert and Thiéry (1910:146) consider the genus to be Balanocidaris. They cite Laube (1865a:284, pl. 9: fig. 13).

Cidaris lanceata Stoppani, 1857:412; Rhaetian.
Cidaris linearis Münster, in Wissmann and Münster, 1841:45, pl. 3: fig. 19; early Karnian.

Cidaris milierensis Zardini, 1973a:23, pl. 12: figs. 19-20, 21a-b; early Karnian.

Cidaris ovata Zardini, 1973a:18, pl. 8: figs. 23a-26c; early Karnian.

Cidaris perplexa Desor, 1855:21, pl. 2: fig. 15; Karnian. Bather (1909:191), in selecting lectotype, makes this species an objective synonym of $C$. subspinulosa D'Orbigny.

Cidaris petersii Laube, 1865a:284, pl. 8b: figs. 5a-c; early Karnian.

Cidaris plana Zardini, 1973a:22, pl. 12: figs. 45a-b, pl. 15: fig. 20, pl. 19: figs. 2a-c, pl. 22: fig. 4; early Karnian.

Cidaris pyramidalis Leonardi and Lovo, 1950:10, pl. 2: figs. 25a-c; early Karnian.

Cidaris quadrialata, Zardini, 1973a:28, pl. 10: fig. 27; early Karnian.

Cidaris quadriserrata Zardini, 1973a:24-25, pl. 13: figs. 1, 2, 4, pl. 22: fig. 6; early Karnian.

Cidaris regnyi Lambert, 1905:94; Norian. See de Regny (1903:464, pl. 2: figs. 2-8).

Cidaris remifera Münster, in Wissmann and Münster, 1841:43, pl. 3: fig. 12; early Karnian.

Cidaris remifera Assmann, 1937:23-24, pl. 5: fig. 17; early Muschelkalk. Name is preoccupied by $C$. remifera Münster, 1841, in Wissmann and Münster (1841:43, pl. 3: fig. 12)

Cidaris reticulata Zardini, 1973a:25, pl. 13: figs. 9-12; early Karnian.

Cidaris roemeri Wissmann, in Wissmann and Münster, 1841:47-48, pl. 4: figs. 3a-g; early Karnian.

Cidaris schwageri Wöhrmann, 1889:194-195, pl. 5: figs. 16, 17; Karnian.

Cidaris scrobiculata Braun, in Wissmann and Münster, 1841:45, pl. 3: figs. 2la,b; early Karnian.

Cidaris seelandica Zardini, 1973a:16-17, pl. 11: figs. 1-11, pl. 21: fig. 4; early Karnian.

Cidaris semicostata Münster, in Wissmann and Münster, 1841:45, pl. 3: figs. 20a,b; early Karnian.

Cidaris similis Desor, 1855:22, pl. 2: fig. 28; Karnian.

Cidaris spinachristi Stoppani, 1857:413; Rhaetian.

Cidaris spongiosa Zardini, 1973a:22, pl. 12: figs. 47a-50, pl. 17: figs. 5a-8c, pl. 18: figs. 10a-13d; early Karnian.

Cidaris slipes Stoppani, 1860-1865:97, pl. 19: fig. 21; Rhaetian.

Cidaris stoppanii de Loriol, in Desor and de Loriol, 18681872:3-4, pl. 1: figs. 1-3; Rhaetian. Name erected by de Loriol for Cidaris verticillata Stoppani (1857:413), which was preoccupied by Cidaris verticillata Lamarck (1816:5657, pl. 136: figs. 2-3).

Cidaris sulcata Zardini, 1973a:22, pl. 12: figs. 12a-17; early Karnian.

Cidaris tenuicostata Zardini, 1973a:25, pl. 13: figs. 8a,b, pl. 19: figs. 4a,b, pl. 22: fig. 5; early Karnian.

Cidaris tetraedrica Zardini, 1973a:16, pl. 7: figs. 21-26b; early Karnian.

Cidaris transversa von Meyer, 1847:576; Norian. Figured by Schauroth (1859:293-294, pl. 1: figs. 8a-d). Lambert (1927:9) designated it a new species, $C$. gilletae. 
Cidaris trapezoidalis Zardini, 1973a:22, pl. 12: figs. 42a-44b, 46a,b; early Karnian.

Cidaris trigona Münster, in Wissmann and Münster, 1841:44, pl. 3: fgs. 15a,b; early Karnian.

Cidaris triserrata Laube, 1865a:294, pl. 10: figs. 11a-c; early Karnian.

Cidaris tyrolensis Desor, 1855:20, pl. 2: figs. 7a,b; Karnian. Bather (1909:224) selects a lectotype that is also the lectotype of $C$. roemeri, thus making $C$. tyrolensis an objective synonym of $C$. roemeri.

Cidaris undulatus Quenstedt, 1875:199, pl. 68: fig. 98; Karnian.

Cidaris valparolae 7ardini, 1973a:28, pl. 18: figs. 30-31; early Karnian.

Cidaris verticillata Stoppani, 1857:413; Rhaetian.

Cidaris verticillata Zardini, 1973a:23, pl. 18: figs. 6-9c; early Karnian. Name preoccupied by Stoppani, 1857.

Cidaris waechteri Wissmann, in Wissmann and Münster, 1841:48, pl. 5: fig. 22; early Karnian.

Cidaris wissmanni Desor, in Agassiz and Desor, 1846:330; Karnian.

Cidaris zardini Leonardi and Lovo, 1950:9-10, pl. 2: figs. 2la-24a, 26b; Karnian.

Hemicidaris gracilis Stoppani, 1857:413; Rhaetian.

Hemicidaris obliquelineata Stoppani, 1857:413; Rhaetian.

Plegiocidaris senex Lambert, 1900:48; Rhaetian. Lambert erected this name to replace Winkler's (1859:26, pl. 2: fig. 9) Cidaris desori, which was preoccupied by $C$. desori Cotteau, in Cotteau and Triger (1857:19).

Radiolus adametzi Jekelius, 1936:49-50, pl. 2: figs. 50a,b, 5la,b; Late Triassic.

Radiolus alutensis Jekelius, 1936:49, pl. 2: fig. 46; Late Triassic.

Radiolus antipai Jekelius, 1936:50-51, pl. 2: figs. 48a,b; Late Triassic.

Radiolus boletus Bather, 1929:239-241, pl. 258: figs. 36a-e, 37. 38; Late(?) Triassic.

Radiolus complanalus Quenstedt, 1875:196, pl. 68: figs. 87a-c; Triassic. Bather (1909:224) selected a lectotype.

Radiolus culter Bather, 1929:241-243, pl. 258: figs. 39a,b, 40a,b, 4 la ,b; Late(?) Triassic.

Radiolus festuca Bather, 1929:244-245, pl. 258: figs. 46, 47. 48a,b; Late(?) Triassic.

Radiolus fusus Bather, 1929:245-246, pl. 258: fig. 49; Late(?) Triassic.

Radiolus herbichi Jekelius, 1936:50, pl. 2: fig. 45; Late Triassic.

Radiolus lineola Bather, 1909:230-231; Karnian.

Radiolus penna Bather, 1909:218-219, pl. 13: figs. 404-412; Karnian.

Radiolus racadaui Jekelius, 1936:49, pl. 2: figs. 47a-c; Late Triassic.

Radiolus raiblianus Bather, 1909:216-218, pl. 13: figs. 399403, pl. 16: figs. 450-451; Karnian.

Radiolus rostratus Körner, 1937:163-164, pl. 11: figs. la-c; Triassic (? Cassian-Raiblian).

Radiolus segmentatus Bather, 1929:236-238, pl. 258 (2): figs. 27a-c, 28, 29a,b; Late (?) Triassic.

\section{Species Based on Fragments}

Anaulocidaris faurai Lambert, 1927:7-8, pl. 1, figs. 1-5; late Muschelkalk-Ladinian.

Anaulocidaris testudo Bather, 1909:140-141, pl. 7, figs. 164187, pl. 10, figs. 256-272; Karnian.

Anaulocidaris vinassai Boni, 1939:328-332, pl. 17, figs. 6-10, 17; Karnian.

Aplocidaris helenae (de Regny).-Lambert and Thiéry, 1909a:31; 1910:140.

Cidaris helenae de Regny, 1903:463, pl. 2, fig. 1.

Because of the generosity of Dr. Antonietta Padovani, I was able to borrow for study the holotype (Figure 16; Plate 21: figure 12) and only known specimen of this species. It is in the collections of the Istituto di Geologia e Paleontologia at the Università di Bologna.

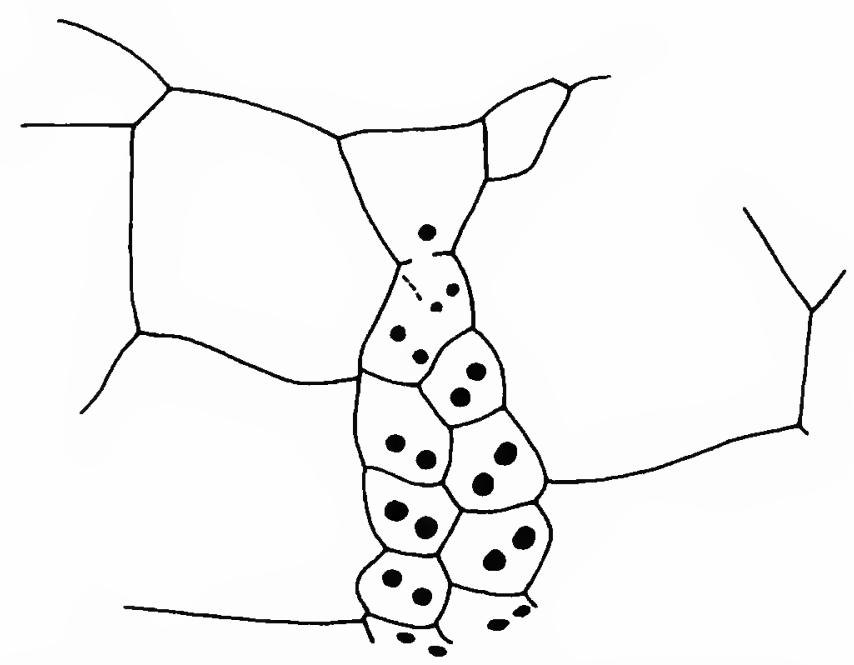

Figure 16.-Aplocidaris helenae (de Regny), adapical view of an ambulacrum of the holotype showing that the ambulacra extend to the ocular plates, $\times 12$. (For a photograph of this specimen, see Plate 21: figure 12.)

The specimen is very poorly preserved with most of the surface of the test broken away removing all traces of the tubercles. Without any information on the nature of the tubercles, it is not possible to determine the familial affinities of this species. The ambulacral plates are very high with large pore-pairs occupying most of the area of the plates. Similar ambulacral plates are found in Mikrocidaris of the Cidaridae and Megaporocidaris, new genus, of the Psychocidaridae. In Mikrocidaris the ambulacra do not reach the ocular plates in an adult; whereas, they do in Aplocidaris helenae (Figure 16). Because only one species is known of Mikrocidaris, however, it is not possible to know the generic significance of this separation. If the tubercles of $A$. helenae are perforate, this species probably would be referred to Mikrocidaris; but if they are imperforate, to Megaporocidaris.

Occurrence.-Late Triassic, Norian, of Montenegro, Yugoslavia.

Cidaris admeto Braun, in Wissmann and Münster, 1841:40, pl. 3: fig. 3.

Rhabdocidaris admeto (Braun).-Laube, 1865a:296. 
The type specimen of this species has been lost for many years, and it is impossible from Braun's illustrations to generically identify this species. Quenstedt (1875:209-210, pl. 68: figs. 149-144) referred two other specimens from the St. Cassian Beds to this species (Plate 21: figures 10-11). Lambert (1910:30) considered one of the specimens (Quenstedt, 1875, pl. 68, fig. 144) to be similar to Triadocidaris liagora (Münster); but he felt that the other specimen was noncidaroid and referred it to Mesodiadema. Bather (1909:115) stated that this specimen might equally well be Hemipedina. Mortensen (1940:81) felt uncertain that this specimen was Mesodiadema because so little was known of its ambulacra and Quenstedt's figure was poor.

I have studied both of Quenstedt's specimens which are housed in the Institut für Geologie und Paläontologie der Universität at Tübingen. Both appear to be cidaroids and may belong to Triadocidaris. Quenstedt's figure 143 is misleading. He shows the primary tubercles as being smaller than they are. As can be seen in photographs of this specimen (Plate 21: figure 11), the primary tubercles are typically cidaroid in size. The interambulacrum is beveled along the adradial margin. Denticles are present on the inner edge as typical in Triadocidaris. Finally, the inner adoral margin thickens into what were probably apophyses. There is no evidence that this specimen might be a noncidaroid.

The specimen Quenstedt used in his figure 144 (see Plate 21: figure 10) had been badly damaged in earlier preparation, and much of the surface ornament had been scraped away. It appears to be specifically different from his other specimen. Its interradial zone is wider with its primary tubercles farther apart transversely than in the other specimen. Denticles 'are present on the beveled adradial margin suggesting that this specimen is probably a Triadocidaris. Both of these specimens are too poorly preserved to warrant specific description. Neither can be selected as the neotype of Cidaris admeto because Braun's illustrations and description are not sufficiently detailed to be certain that either specimen is conspecific with $C$. admeto.

Zardinechinus lancedelli (Zardini) appears to be very similar to Braun's Cidaris admeto and may be conspecific. Until the type specimen of $C$. admeto has been found, it is impossible to be certain whether the taxa are conspecific. It seems best to maintain Zardini's species. Two of the specimens that Zardini referred to $C$. admeto (1973a, pl. 5: figs. 34a, b) and $C$. cfr. admeto (1973a, pl. 6: figs. 11a, b) are here referred to $Z$. lancedelli (for further details see Z. lancedelli).

Three other specinens which Zardini (1973a: pl. 5: figs. $28 \mathrm{a}, \mathrm{b}, 29 \mathrm{a}, \mathrm{b}, 33 \mathrm{a}, \mathrm{b})$ referred to Cidaris admeto have imperforate tubercles and are herein referred to Levicidaris zardinia, new species.

Cidaris cornaliae Stoppani, 1857:412; 1860-1865:94, pl. 19: figs. 4, 5. Upper zone of the Rhaetian Avicula contorta beds in Lombardy. Although this species was based on an almost complete test, the type specimen has been lost (see account under Diademopsis? desori (Stoppani)) and it is impossible from the original description and poor illustrations to generically identify it.

Cidaris crenulata Leonardi and Lovo, 1950:6, pl. 2: figs. 2729; early Karnian.

Cidaris curionii Stoppani, 1857:411; 1860-1865:94, pl. 19: figs. 1-3; upper zone of the Rhaetian Avicula contorta beds in Lombardy. Although this species was based on an almost complete test, the type specimen has been lost (see account under Diademopsis? desori (Stoppani)), and it is impossible from the original description and poor illustrations to generically identify it.

Cidaris fumagalli Stoppani, 1860-1865:95, pl. 9: figs. 8, 9; upper zone of the Rhaetian Avicula contorta beds in Lombardy. Although this species was based on an almost complete test, the type specimen has been lost (see account under Diademopsis? desori (Stoppani)), and it is impossible from the original description and poor illustrations to generically identify it.

Cidaris klipsteini Desor, 1855:4; Karnian. Isolated interambulacral plate. Bather (1909:84) gave a new name to this species-Miocidaris cassiani-since Cidaris klipsteini Desor was preoccupied by Cidaris klipsteini Marcou (in Agassiz and Desor, 1846-1847), which was based on a radiole only.

Cidaris lanceolata Schauroth, 1859:291-293, pl. 1: figs. 7a-d; Muschelkalk, Norian.

Cidaris leonardi Zardini, 1973a:11-12, pl. 5: fig. 13; early Karnian. Part of interambulacrum.

Cidaris liagora Münster, in Wissmann and Münster, 1841:41, pl. 3: fig. 5; early Karnian. Interambulacrum.

Cidaris longispina Assmann, 1937:22-23, pl. 5: figs. 7-10; early Ladinian. Spines and badly preserved portion of a test. Originally Radiolus subnodosus H. Eck, 1865.

Cidaris magna Leonardi and Lovo, 1950:5, pl. 2: fig. 26; early Karnian. Isolated interambulacrum plate.

Cidaris ombonii Stoppani, 1857:409; 1860-1865:95, pl. 19: figs. 6. 7; upper zone of the Rhaetian Avicula contorta beds in Lombardy. Although this species was based on an almost complete test, the type specimen has been lost (see account under Diademopsis? desori (Stoppani)), and it is impossible from the original description and poor illustrations to generically identify it.

Cidaris shastensis Clark, in Clark and Twitchell, 1915:23, pl. 1: fig. 5; Late Triassic. Single fragment.

Cidaris staulinensis Leonardi and Lovo, 1950:6, pl. 2: fig. 30; early Karnian. Adapical portion of ambulacrum and interambulacrum.

Cidaris subcoronata Münster, in Wissmann and Münster, 1841:40, pl. 3: fig. 1; early Karnian. One large and one small plate (interambulacral).

Eocidaris laubei Lambert, 1900:39; early Karnian. An isolated interambulacral plate.

Mesodiadema latum Bather, 1909:118-123, pl. 8: figs. 198-211; Karnian. Isolated interambulacral plates.

Mesodiadema margaritatum Bather, 1909:117-118, pl. 8: figs. 192-197; Karnian(?). Fragments of interambulacra. Mortensen (1940:81) says: "But as long as these species are only so imperfectly known there is no proof that they are not really Cidarids . . . ." 
Miocidaris adrianae Zardini, 1973a:9, pl. 6, fig. 25; early Karnian. Part of an interambulacrum.

Miocidaris ampezzana Zardini, 1973a:9, pl. 6: figs. 23a,b, 26ac; early Karnian. Part of interambulacra.

Miocidaris barzaviae Jekelius, 1936:43-44, pl. 2, figs. 24-26; Late Triassic. Isolated interambulacral plates.

Miocidaris cassiani Bather, 1909:84; Karnian(?). Two interambulacral fragments figured by Klipstein (1845:272, 274, pl. 18: figs. 15, 16) now in British Museum (BM 36512, 36513). Bather selected 36512 (Klipstein's figure 15) as lectotype and gave the species the new name $M$. cassiani. Miocidaris cortinensis Zardini, 1973a:9, pl. 6: figs. 28-29; pl. 19: fig. 7; early Karnian. Three portions of interambulacra. Miocidaris curmaturi Jekelius, 1936:43, pl. 2: figs. 21-22; Late Triassic. Part of an interambulacrum.
Miocidaris planus Bather, 1909:91-92, pl. 7: figs. 157-159; Karnian. Interambulacral plates.

Miocidaris timorensis Bather, 1929:228-232, pl.: 257(1): figs. 18, 19a-c, 20; Upper(?) Triassic. Part of an interambulacrum. Miocidaris verrucosus Bather, 1909:90-91, pl. 6: figs. 153-156; Karnian. Interambulacra.

Triadocidaris coronensis Jekelius, 1936:44, pl. 2: figs. 20a-c; Late Triassic. One interambulacral plate.

Triadocidaris lungauensis Tollmann, in Kristan-Tollmann, Tollmann, and Geyssant, 1969:21-23, pl. 3: figs. 3-6, pl. 6: figs. 5-8; Rhaetian. Fragments of test and spines.

Triadocidaris praeternobilis Bather, 1909:76-78, pl. 6: figs. 135-138; Karnian. Interambulacra.

Triadocidaris subnobilis Münster, in Wissmann and Münster, 1841:42-43, pl. 3: fig. 10; early Karnian. Interambulacral plate.

\section{Corrected Occurrences}

Lambert and Thiéry (1909-1925) incorrectly referred to the Rhaetian the following Early Jurassic species.

Diadema microporum Agassiz, in Leymerie, 1838:365. Lambert and Thiéry (1910:198) consider this species to be Rhaetian, and Cotteau (1883:451) places it in the "Infralias"; but Desor (1858:80) puts it in the Lias; and Cotteau (1858:220), in the "Lias inferieur (étage sinèmurien)."

Diademopsis heeri Merian, in Desor, 1858:80, pl. 13: figs. 1, 2. Lambert and Thiéry (1910:198) place in the Rhaetian; but other authors (Desor, 1858:80; Desor and Loriol, 18681872:184; Cotteau, 1883:474; and Tornquist, 1908, pl. 16: figs. 1, 2, explanation) place this species in the Early Juras. sic (Liassic). Lambert (1900:16) himself states that this species is from the Hettangian-Sinemurian. Lambert evidently used Rhaetian in the sense of Early Liassic.

Diademopsis parvituberculata Böhm, 1884:762, pl. 16: figs. 1-3. Although Lambert and Thiéry (1910:200) consider this species Rhaetian, it is from the Grauen Kalke der Südalpen, which according to Gïrich (1934:443) is Early Jurassic (Liassic).

Hemipedina michelini Cotteau, 1858:220, pl. 6: figs. 2, 3. Lambert and Thiéry (1910:198) place in Rhaetian, but this species is from the Psiloceras planorbis zone, which according to all modern workers is Early Jurassic (Hettangian).

Pseudodiadema veronensis Böhm, 1884:761, pl. 15: figs. 1-3. Rhaetian according to Lambert and Thiéry (1910:186), but this species is from the Grauen Kalke der Südalpen, which according to Gürich (1934:443) is Early Jurassic (Liassic). 


\section{Literature Cited}

Agassiz, J. L. R., and P. J. E. Desor

1846-1847. Catalogue raisonné des familles, des genres et des espèces de la classe des Echinodermes, \&ec. $A n$ nales des Sciences Naturelles (Paris), series 3, 6:305374; [Bather (1909:265) notes that "the last part of this work was edited by Jules Marcou, and contains notes by him."]

Assmann, $\mathrm{P}$.

1926. Die Fauna der Wirbellosen und die Diploporen der oberschlesischen Trias mit Ausnahme der Brachiopoden, Lamellibranchiaten, Gastropoden und Korallen. Jahrbuch der PreuBischen Geologischen Landesanstalt zu Berlin for 1925, 46:504-527, plates $8,9$.

1937. Revision der Fauna der Wirbellosen der oberschlesischen Trias. Abhandlungen der PreuBischen Geologischen Landesanstalt (Berlin), new series, 170:1-134, plate 5 .

Bather, F. A.

1909. Triassic Echinoderms of Bakony. 288 pages, 63 figures, 18 plates. Budapest.

1929. Triassic Echinoderms of Timor. Paläontologie von Timor, 16(30):215-272, plates 257-258.

Böhm, G.

1884. Beiträge zur Kenntnis der grauen Kalke in Venetien. Zeitschrift des Deutschen Geologischen Gesellschaft, 36:787-782, 1 unnumbered figure, plates 15-26.

Boni, A.

1939. Fauna anisica pigmea scoperta nelle prealpi bresciane. Bollettino della Società Geologica Italiana, 58(2-3):321-428, plates 17-22.

Clark, W. B., and M. W. Twitchell

1915. The Mesozoic and Cenozoic Echinodermata of the United States. Monographs of the United States Geological Survey, 54:1-341, plates 1-108.

Cotteau, G. $\mathbf{H}$.

1858. Echinides nouveaux ou peu connus. Revue et Magasin de Zoologie Pure et Appliquée, (2)10:212224, plates 5-6.

1875-1880. Échinides réguliers: Familles des Cidaridées et des Salénidées. Part 1 in volume 10 (Terrain Jurassique) of series 1 (Description des animaux invertébrés) in D'Orbigny, Paleontologie Française. Plates 143-262. Paris: G. Masson, éditeur.

1880-1885. Échinidés réguliers: Familles des Diadematidées et des Échinidées. Part 2 of volume 10 (Terrain Jurassique) of series 1 (Animaux Invertébrés) in [D'Orbigny], Paleontologie Française. Plates 263520. Paris: G. Masson, éditeur.

Cotteau, G. H., and J. Triger

1857-1869. Échinides du Départment de la Sarthe. 455 pages, 75 plates, 2 tables. Paris: J. B. Bailliere et Fils.

de Regny, P. V.

1902-1904. Fossili del Montenegro. Memorie della $R$. Accademia delle Scienze dell'Istituto di Bologna, series 5, 10:447-471, plates 1, 2.

Desor, E.

1855-1858. Synopsis des Échinides fossiles. 490 pages. Paris.

Desor, E., and P. de Loriol

1868-1872. Échinides de la Période Jurassique. Part I in Description des Oursins Fossiles de la Suisse in Échinologie 'Helvétique. 441 pages, atlas, 61 plates.

Döderlein, $\mathbf{L}$.

1887. Familie Cidaridae und Saleniidae. Part 1 of Döderlein, Die Japanischen Seeigel. 11 plates. Stuttgart: E. Schweizerbortische Verlagshandlung.

1906. Die Echinoiden der deutschen Tiefsee-Expedition. Pages 61-290 in volume 5 of Wissenschaftliche Ergebnisse Deutschen Tiefsee-Expedition auf dem Dampfer "Valdivia." Figures 1-46, plates 9-50.

D'Orbigny, M. A.

1849. Prodrome de Paleontologie Stratigraphique Universelle des Animaux Mollusques et Rayonnes. Volume 1, 394 pages. Paris.

Durhain, J. Wyatt, editor

1966. Treatise on Invertebrate Paleontology. New York: Geological Society of America; Lawrence: University of Kansas Press.

Durham, J. W., and R. V. Melville

1957. A Classification of the Echinoids. Journal of Paleontology, 31(1):242-272, figures 1-9.

Eck, $\mathbf{H}$.

1865. Ueber die Formalionen des bunten Sandsteins und des Muschelkalks in Oberschlesien und ihre Versteinerungen. 154 pages, 2 plates. Berlin.

Fell, H. B.

1950. A Triassic Echinoid from New Zealand. Transactions of the Royal Society of New Zealand, 78(1):8385, figures $1-3$, plate 12 .

1966a. Cidaroids. Pages U312-U339 in volume 3 of Part U (Echinodermata) in J. Wyatt Durham, editor, Treatise on Invertebrate Paleontology. Figures 235-254. New York: Geological Society of America; Lawrence: University of Kansas Press.

1966b. Diadematacea. Pages U340-U366a in volume 3 of Part U (Echinodermata) in J. Wyatt Durham, editor, Treatise on Invertebrate Paleonlology. Figures 255271. New York: Geological Society of America; Lawrence: University of Kansas Press.

Giebel,

1853. Beitrag zur Palaeontologie des Texanischen Kreide- 
gebirges. Jahresbericht des Naturwissenschaftlichen vereines in Halle, 1852:358-375, plates 6.7.

Goldfuss, A.

1826. Petrefacta [Germaniae:] Musei Universitatis Regtae Borussicae Rhenanae Bonnensis nec non Hoening. husiani Crefeldensis. Volume 1/2, 224 pages, 146 plates [in separate volume]. Düsseldorf: Arnz.

Gregory. J. W.

1896. On Lysechinus, a New Genus of Fossil Echinoderms from the Tyrolese Trias. Proceedings of the Zoolog. ical Society of London, 1896:1000-1005, plate 51.

Gürich, G.

1934. Leitfossilien: Ein Hilfsbuch zum Bestimmen von Versteinerungen bei geologischen Arbeiten in der Sammlung und im Felde. Volume 7. Berlin: Verlag von Gebrüder Borntraeger.

Hudson, R. G. S., and R. P. S. Jefferies

1961. Upper Triassic Brachiopods and Lamellibranchs from the Omar Peninsula, Arabia. Palaeontology, 4(1):41, figures 1-12, plates $1,2$.

Jeannet, A.

1933. B. Peyer, Die Triasfauna der Tessiner Kalkalpen, VI: Note sur un Miocidaris nouveau. Abhandlungen der Schweizerischen Palaeontologischen Gesellschaft, 53:1-7, figures 1, 2, plate 30 .

Jekelius, E.

1936. Der weisse Triaskalk von Braşov und seine fauna. Anuarul Institutului Geologic al Romaniei (Annuaire de l'Institut Géologique de Roumainie), 17:1107, plates 1-9, 1 chart.

Jesionek-Szynıańska, $W$.

1967. Sur un caractère archaïque chez des Echinides irréguliers. Comple Rendus de l'Academie des Sciences (Paris), (D)264:2982-2985, figures 1-10. [Translated by Roman Kozłowski. Paris.]

1968. Irregular Echinoids: An Insufficiently Known Group. Lethaia (Oslo), 1(1):50-62, figures 1-11.

Kier, P. M.

1956. Separation of Interambulacral Columns from the Apical System in the Echinoidea. Journal of Paleontology, 30(4):971-974, figures 1-3.

1965. Evolutionary Trends in Paleozoic Echinoids. Journal of Paleontology, 39(3):436-465, figures 1-26, plates 55-60.

1968. The Triassic Echinoids of North America. Journal of Paleontology, 42(4):1000-1006, figure 1, plates 121-123.

1974. Evolutionary Trends and Their Functional Significance in the Post-Paleozoic Echinoids. Journal of Paleontology, 48(2:memoir 5):1-96, figures 1-78, table 1 , chart 1 .

Klipstein, A. von

1845. Mittheilungen aus dem Gebiete der Geologie und Paläontologie, I. Beiträge zur geologischen Kennıniss der ösllichen Alpen, 2/3:14.5-311, plates 9-20.

Körner, K.

1937. Marine (Cassianer-Raibler) Trias am Nevado de Acrotambo (Nord-Peru). Palaeontographica, 86A:145240, figures 1-6. plates 10-14.
Kristan-Tollmanu, E., A. Tollmann, and J. Geyssant

1969. Zur Schichtfolge und Fossilführung des zentralaIpinen (unterostalpinen) Rhät der Tarntaler Berge in Tirol. Jahrbuch der Geologischen Bundesanstalt (Vienna), 112(1):1-29, figure 1, plates 1-6.

Lamarck, J. B. P. A. de M. de

1816. Echinides. Volume 3 in Lamarck, Histoire Naturelle des Antmalux sans Vertebres. Paris.

Lambert, J.

1900. Etude sur quelques échinides de I'Infra-Lias et du Lias. Bulletin de la Société des Sciences Historiques et Naturelles de l'Yonne, 53(2):1-57, figures 1-6, plate 1.

1905. Echinodermes. Revue Critiques de Paléozoologie (Paris), 9(2):91-98.

1924. Sur un échinide nouveau du Rhétian des Préalpes bernoises. Eclogae Geologicae Helvetiae, 18(3):448450. figures 1-2.

1927. Revision des Echinides fossiles de la Catalogne. Memorias del Museo de Ciencias Naturales de Barcelona, Serie Geologica, 1(1):1-102, figures 1-10, plates $1-4$.

Lambert, J., and P. Thiéry

1909-1925. Essai de nomenclature raisonnée des Échinides. 607 pages, 15 plates. Chaumont: Librairie L. Ferrière.

1909a. Notes Echinologiques. Bulletin de la Société de Sciences Naturelles de la Haute-Marne, 24:9-32, plate 1.

Laube, G. C.

1865a. Die Fauna der Schichten von St. Cassian. Denkschriftian der Kaiserlichen Akademie der Wissenschaften, Mathematisch-Naturwissenschaftliche Classe (Vienna), 24:223-296, plates 1-10.

1865b. Die Fauna der Schichten von St. Cassian. Sitzungsberichte der Mathematisch-Naturwissenschaftlichen Classe der Kaiserlichen Akademie der Wissenschaften, 50(1):319-926.

Leonardi, P., and M. Lovo

1950. Nuove forme di echinodermi della fauna cassiana di Cortina d'Ampezzo. Studi Trentini di Scienze Naturali, 27(1-3):3-10, plates 1, 2.

Leymerie, A.

1838. Memoire sur la partie inférieure du système secondaire du Départment du Rhóne. Mémoires de la Société Géologique de France, 3(9):313-378, plates 23, 24.

Linck, 0 .

1955. Ein bemerkenswerter Seeigel-Rest (Miocidaris pakistanensis n. sp.) aus der Unter-Trias der Salt Range (Pakistan). Neues Jahrbuch für Geologie und Paläontologie, 11:489-495, figures 1-4.

Lovén, $S$.

1883. On Pourtalesia, A Genus of Echinoidea. Kongl. Svenska Vetenskaps-Akademiens Handlingar, new series, 19(7):1-95, 16 unnumbered figures, plates 1-21.

1892. Echinologica. Bihang Till Kungl. Svenska Vetenskaps-Akademiens Handlingar, 18(IV, 1):1-73, 13 
Mortensen, $\mathbf{T}$.

unnumbered figures, plates $1-12$.

1928. A Monograph of the Echinoidea, 1: Cidaroidea. 551 pages, 173 figures, 88 plates. Copenhagen: C. A. Reitzel, Publisher.

1935. A Monograph of the Echinoidea, II: Bothriocidaroida, Melonechinoida, Lepidocentroida, and Stirodonta. 645 pages, 377 figures, 89 plates. Copenhagen: C. A. Reitzel, Publisher.

1940. Aulodonta. Number 1 of volume 3 in A Monograph of the Echinoidea. 370 pages, 197 figures, 77 plates. Copenhagen: C. A. Reitzel, Publisher.

Neumayr, $M$.

1881. Morphologische Studien über fossile Echinodermeı. Sitzungsberichte der Mathematisch-Naturwissenschaftlichen Classe der Kaiserlichen Akademie der Wissenschaften, 84(1):143-176, plates 1, 2.

Philip, G. M.

1965. Classification of Echinoids. Journal of Paleontology, $39: 45-62$, figures $1-4$.

Quenstedt, F. A.

1875. Petrefactenkunde Deutschlands, 1: Die Echiniden. Volume 3. Tübingen. [Plates 62-89 in atlas, which was published in 1874.]

Schauroth, K. von

1859. Kritisches Verzeichniss der Versteinerungen der Trias im Vicentinischen. Sitzungsberichte Kaiserlichen Akademie der Wissenschaften Wien, Mathematisch-Naturwissenschaftliche Classe, 34(1):283-356, plates 1-3.

Silberling, N. J., and E. T. Tozer

1968. Biostratigraphic Classification of the Marine Triassic in North America. Geological Society of America Special Paper, 110:1-63, figure 1, plate 1.

Stefanini, G.

1923 [1924]. Il retico nei dintorni di Selvena (Siena) e i suoi fossili. Bolletino della Società Geologico Italiano, 42:48-57, plate 5 .

Stoppani, A.

1857. Studii Geologici e Paleontologici sulla Lombardia. 461 pages, 4 plates. Milan: Presso Carlo Turati Tipografo.

1860-1865. Monographie des fossiles de l'Azzarola appartenant à la zone supérieure des couches à Avicula contorta en Lombardie. Paléontologie Lombardie ou Description des Fossiles de Lombardie, series 3,
268 pages, 60 plates. Milan.

Thiéry, P.

1928. Considerations phylogéniques les Cidaridae. Archives de Zoologie Expérimentale et Générale (Paris), 67(4):179-181.

Tornquist, A.

1908. Die Diadematoiden des wurttembergischen Lias. Zeitschrift der Deutschen geologischen Gesellschaft (Berlin), 60(3-4):378-430, figures 1-10, plates 15-19.

V'enzo, S.

1934. Ladinico superiore dell'Isola di Rodi (Egeo), II: La fauna. Palaeontographia Italica (Pisa), 34:137-170, figures 1, 2, plate 13 .

voll Meyer, $\mathrm{H}$.

1847. Mittheilungen an Professor Bronn gerichtet. Newes Jahrbuch für Mineralogie, Geognosie, Geologie und Petrefakten-Kunde (Stuttgart), 1847:572-580.

Winkler, G.

1859. Die Schichten des Avicula contorta inner- und ausserhalb der Alpen. 51 pages, 2 plates. Munich: Jah. Palm's Hofbuchhandlung.

Wissmain, H. L., and G. Münster

1841. Beiträge zur Geognosie und Petrefacten-Kunde des Südöstlichen Tirol's vorzüglich der schichten von St. Cassian. 125 pages, 16 plates. Bayreuth.

Wöhrmann, S. von

1889. Die Fauna der sogenanıten Cardita- und RaiblerSchichten in den Nordtiroler und bayerischen Alpen. Jahrbuch der Kaiserlich-Königlichen Geologischen Reichsanstalt (Vienna), 39:181-258, figures $1-6$, plates $5-10$.

Zardini, $R$.

1973a. Fossili di Cortina: Atlante degli echinodermi cassiani (Trias medio-superiore) della regione dolomitica attorno a Cortina d'Ampezzo. 27 pages, 21 unnum. bered figures, 22 plates. Cortina d'Ampezzo, Italy: Foto Ghedina.

1973b. Geologia e Fossili attorno a Cortina d'Ampezzo. 24 pages, 7 plates. Cortina d'Ampezzo, Italy: Foto Ghedina.

Zittel, K. A. von

1879. Echinodermata. Pages $308-560$ in part 3 of volume 1 of Paleozoologie. Volume 1 of von Zittel, Handbuch der Paleontologie. Munich and Leipzig: Eruck und Verlag von R. Oldenbourgh. 

PLATES 1-21 


\section{PLATE 1}

Miocidaris pakistanensis Linck

1. Adapical view of the holotype, Ech. 1058/1, in IGP, $\times 2$. Early Triassic, Scythian, Salt Range, Fundort Mittialiwani bei Chhidru, Pakistan.

\section{Lenticidaris utahensis Kier}

2. Adapical view of the holotype S5088, in NMNH, $\times$ 2. Early Triassic, Scythian, Virgin Formation, lower part of Moenkopi Group, $14 \mathrm{~km}$ SW of St. George, Utah.

3. Adoral view of a paratype 5.5089 , in $\mathrm{NMNH}, \times 2$. Same occurrence as figure 2. 

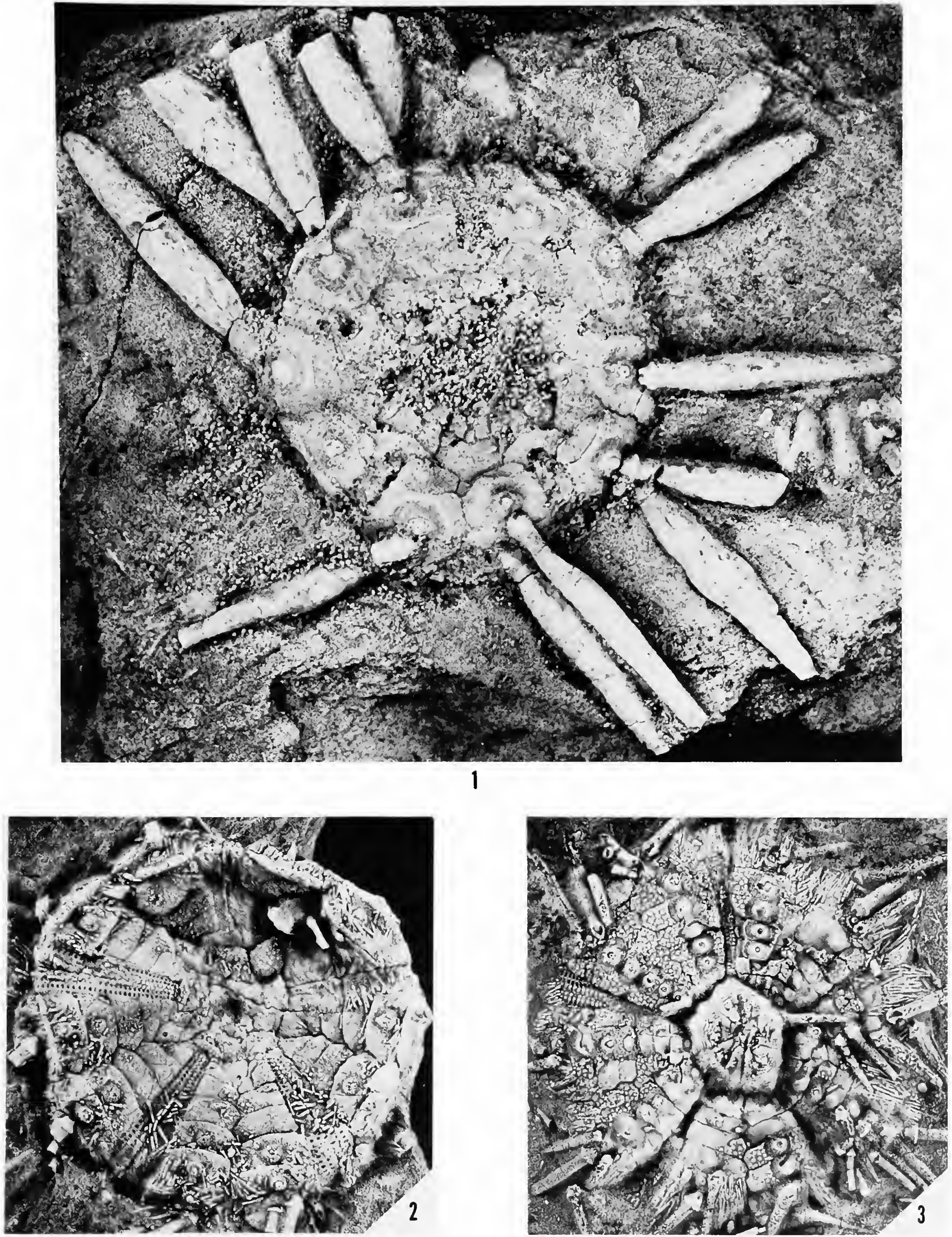


\section{PLATE 2}

\section{Serpianotiaris hescheleri (Jeannet)}

1, 2. Holotype, PIM, $\times 2, \times 5$. Middle Triassic, Ladinian, from near Serpiano (Aqua del Ghiffo, Tessin meridional), Switzerland. (Photographs courtesy of Dr. Hans Rieber.)

\section{Mikrocidaris pentagona (Münster)}

3. Side view of the holotype immersed in xylene, AS VII 392 , in BSPG, $\times 15$. Late Triassic, early Karnian, St. Cassian Beds, Italy.

4, 5, 6. Adapical, adoral, and side views of Zardini's (1973a: pl. 5: figs. 18a-c) 117-G-Z, in MCA $\times$ 15. Late Triassic, early Karnian, St. Cassian Beds, Forcella Giau. Collector: Zardini. 

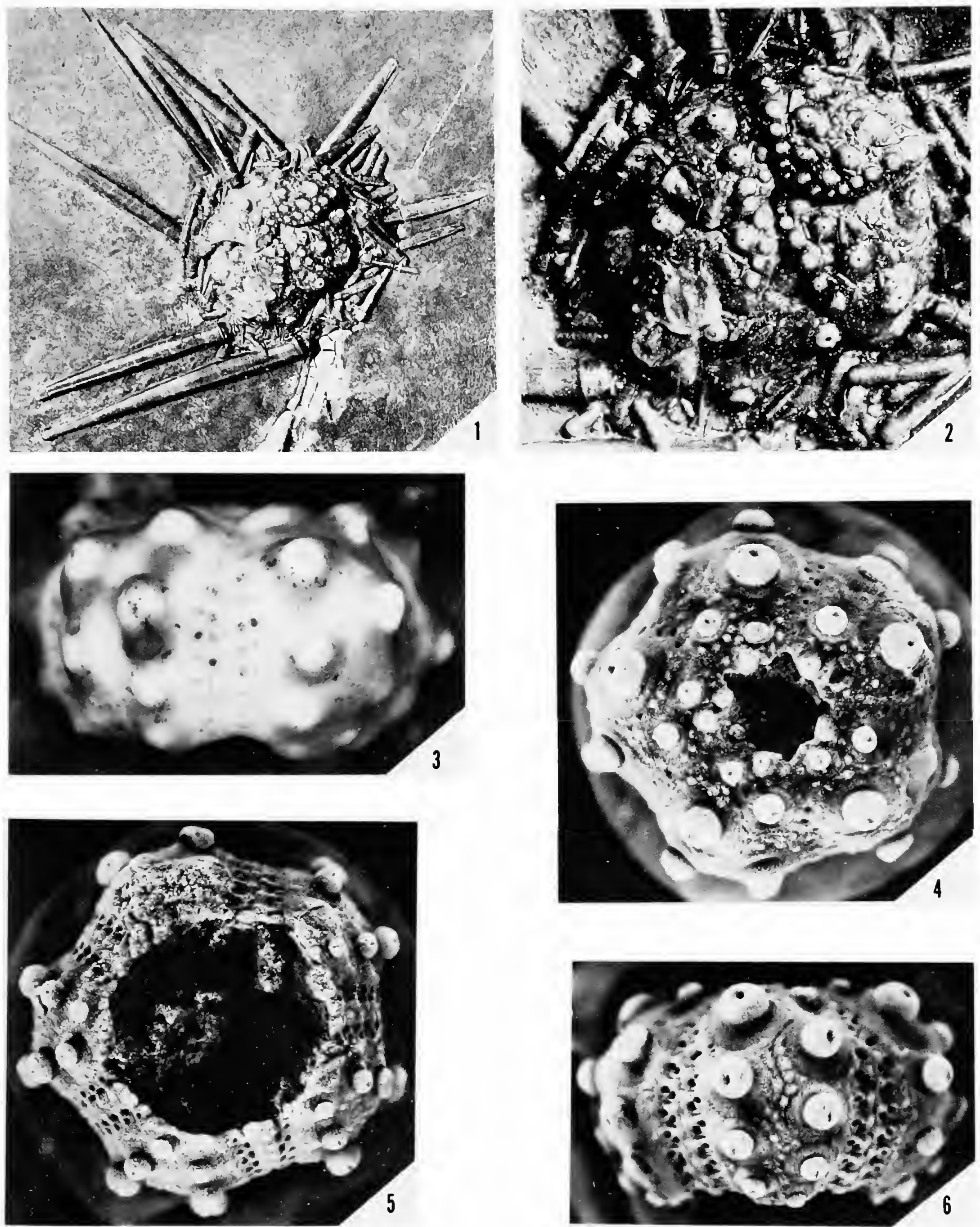


\section{PLATE 3}

\section{Mikrocidaris pentagona (Münster)}

1, 2, 3. Adapical, adoral, and side view at ambulacrum.

4. Side view at interambulacrum.

5. Tilted top view showing ambulacrum not reaching apical system.

6. Tilted lower view, $\times 15$.

All Laube's (1865a, pl. 9: fig. 3) figured specimen 4479, in GB. Late Triassic, early Karnian, St. Cassian Beds, Italy. 

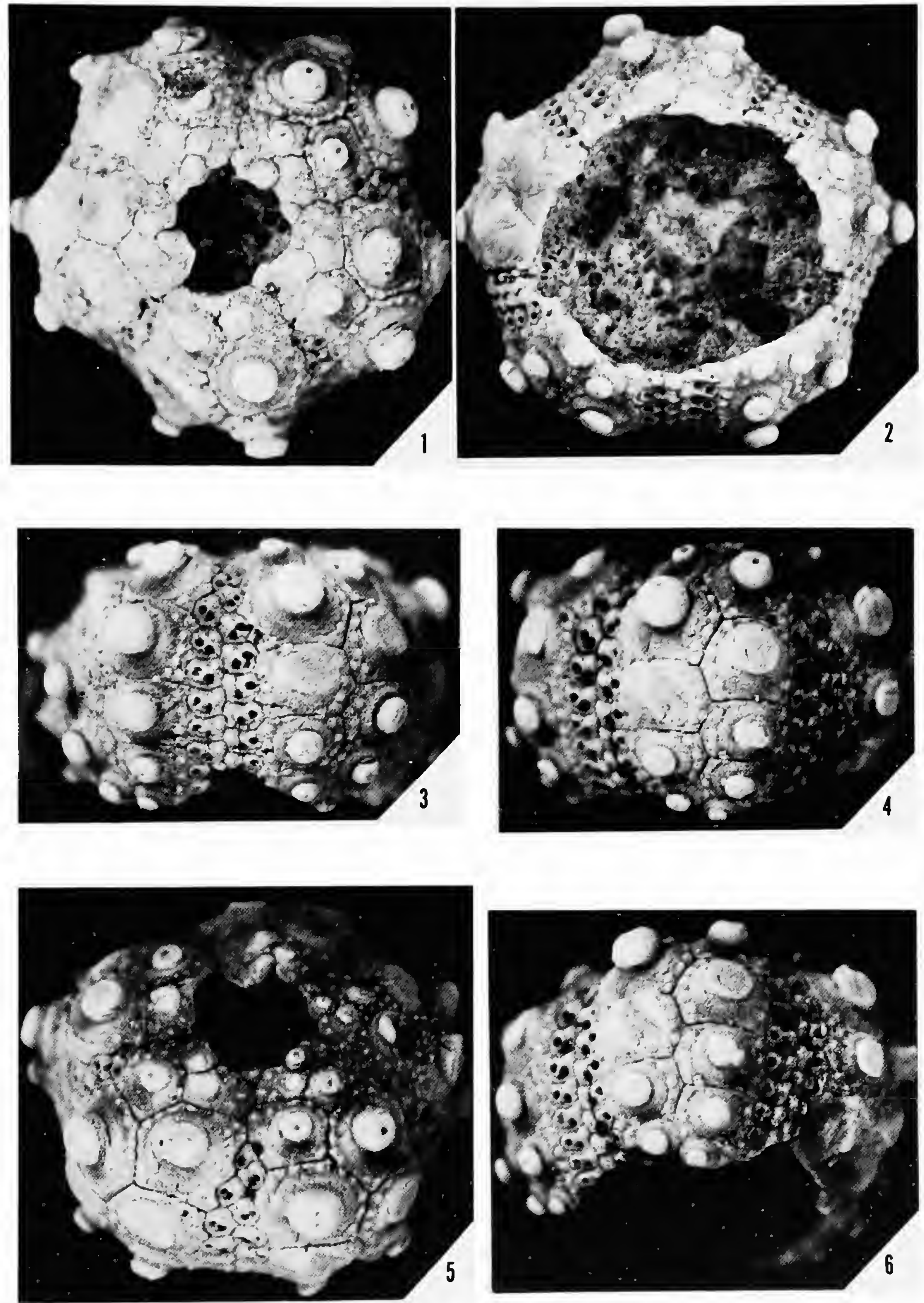


\section{PLATE 4}

Mikrocidaris pentagona (Münster)

1, 2. Adapical and side view of holotype of Cidaris subpentagona Braun, AS VII 438, in BSPG, photographed immersed under xylene, $\times 22$. Late Triassic, early Karnian, St. Cassian Beds, Italy.

\section{Triadocidaris subsimilis (Münster)}

3. Lectotype AS VII 437, in BSPG, $\times$ 4. This is apparently the specimen figured by Laube (1865a, pl. 9: fig. 1c). Late Triassic, early Karnian, St. Cassian Beds, Italy.

4. Side view of Laube's (1865a, pl. 8b: fig. 4) figured specimen, in NM, $\times 4$. Late Triassic, early Karnian, St. Cassian Beds, Italy.

5. Enlarged view of the same Laube specimen (1865a, pl. 8b: fig. 4) adapical to the ambitus showing the high protuberances separating the pores and the beveling of the ambulacral plates under the interambulacra, $\times 12$.

6. Adapical view of the same specimen, $\times 4$. 

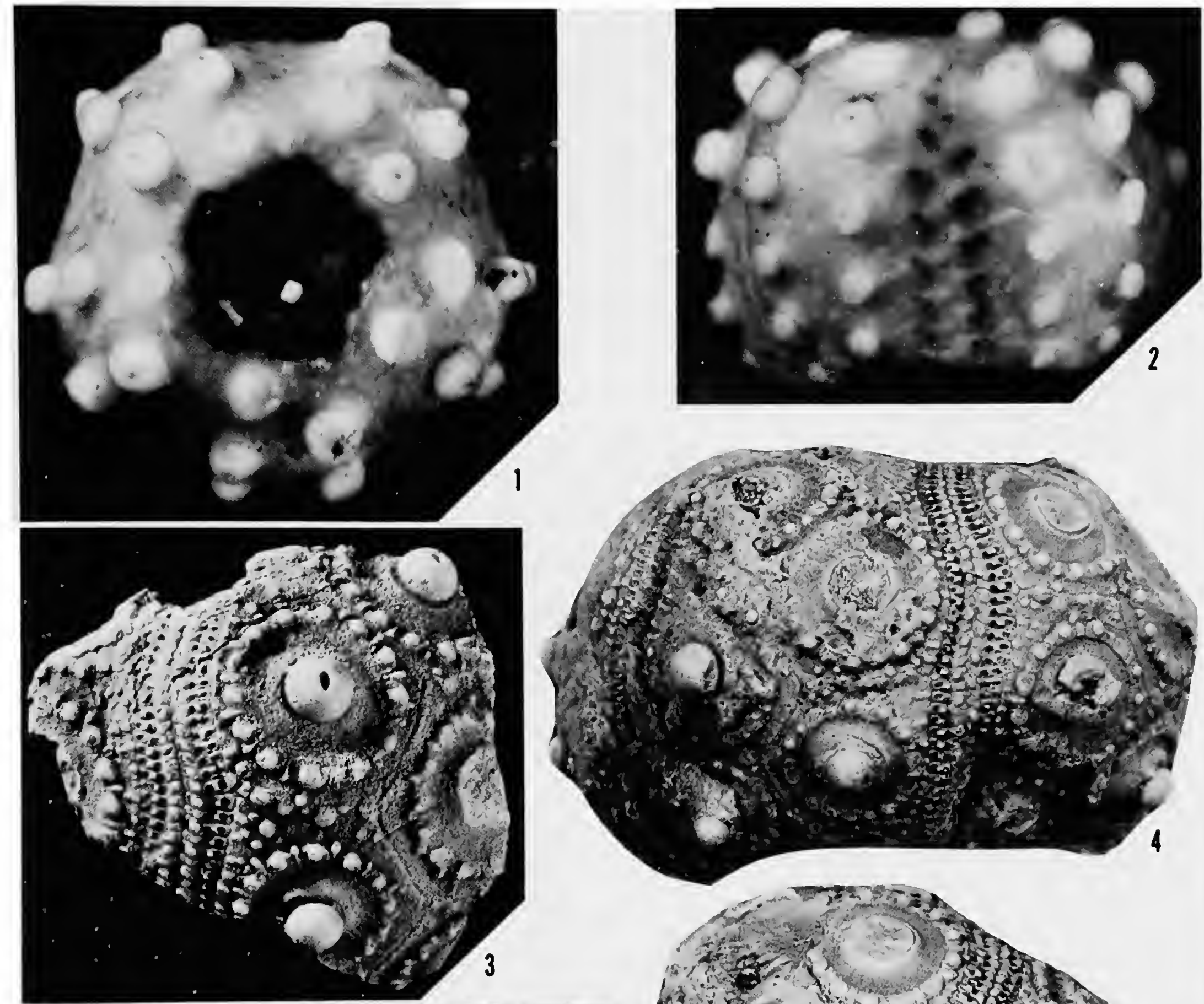

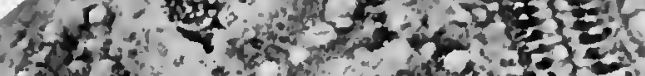

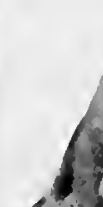

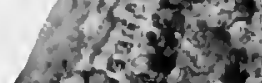

a 0
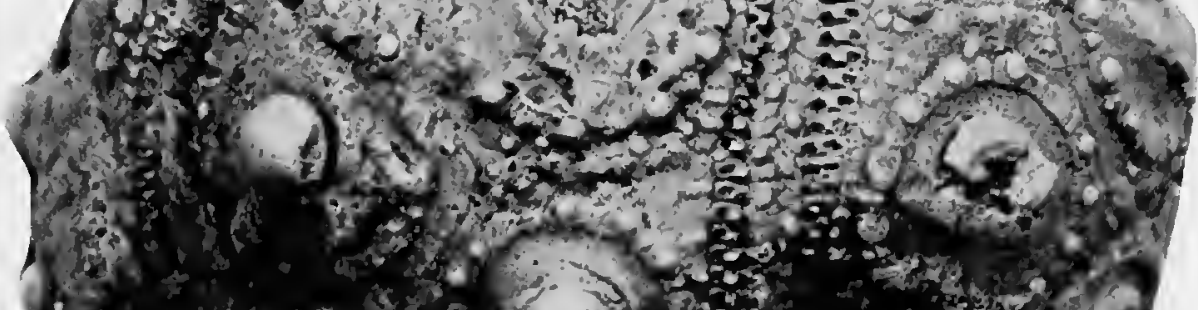

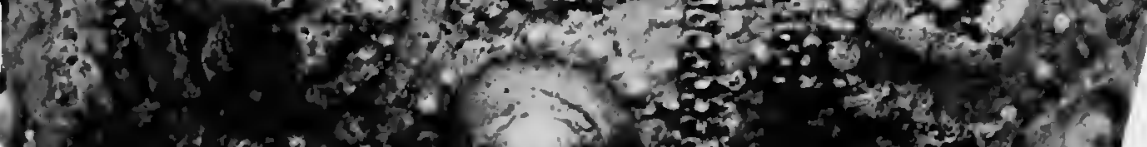

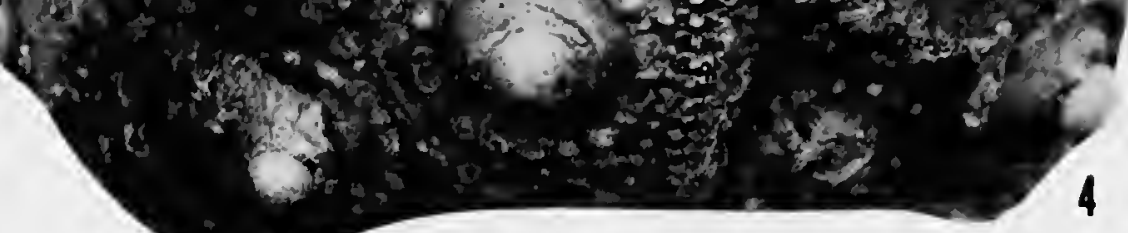

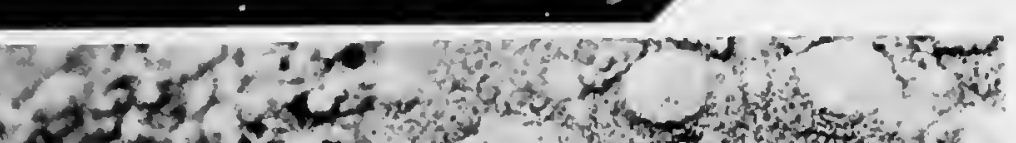

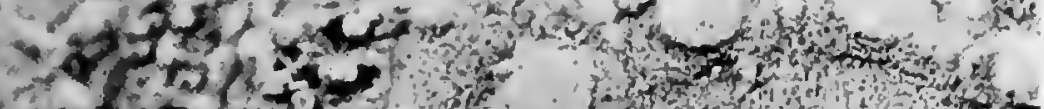

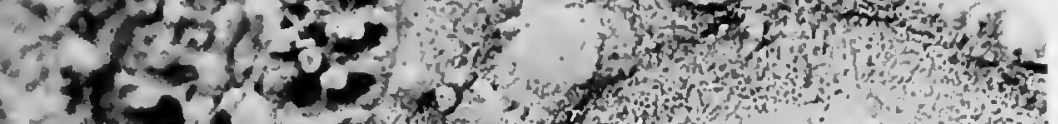

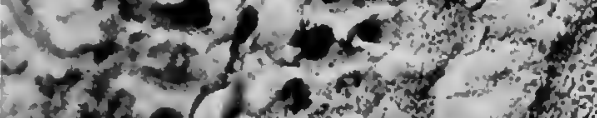

Herian

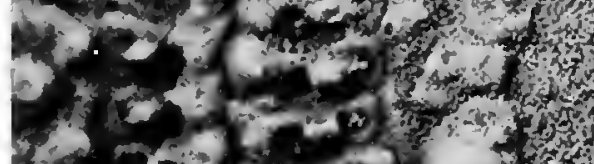

1.
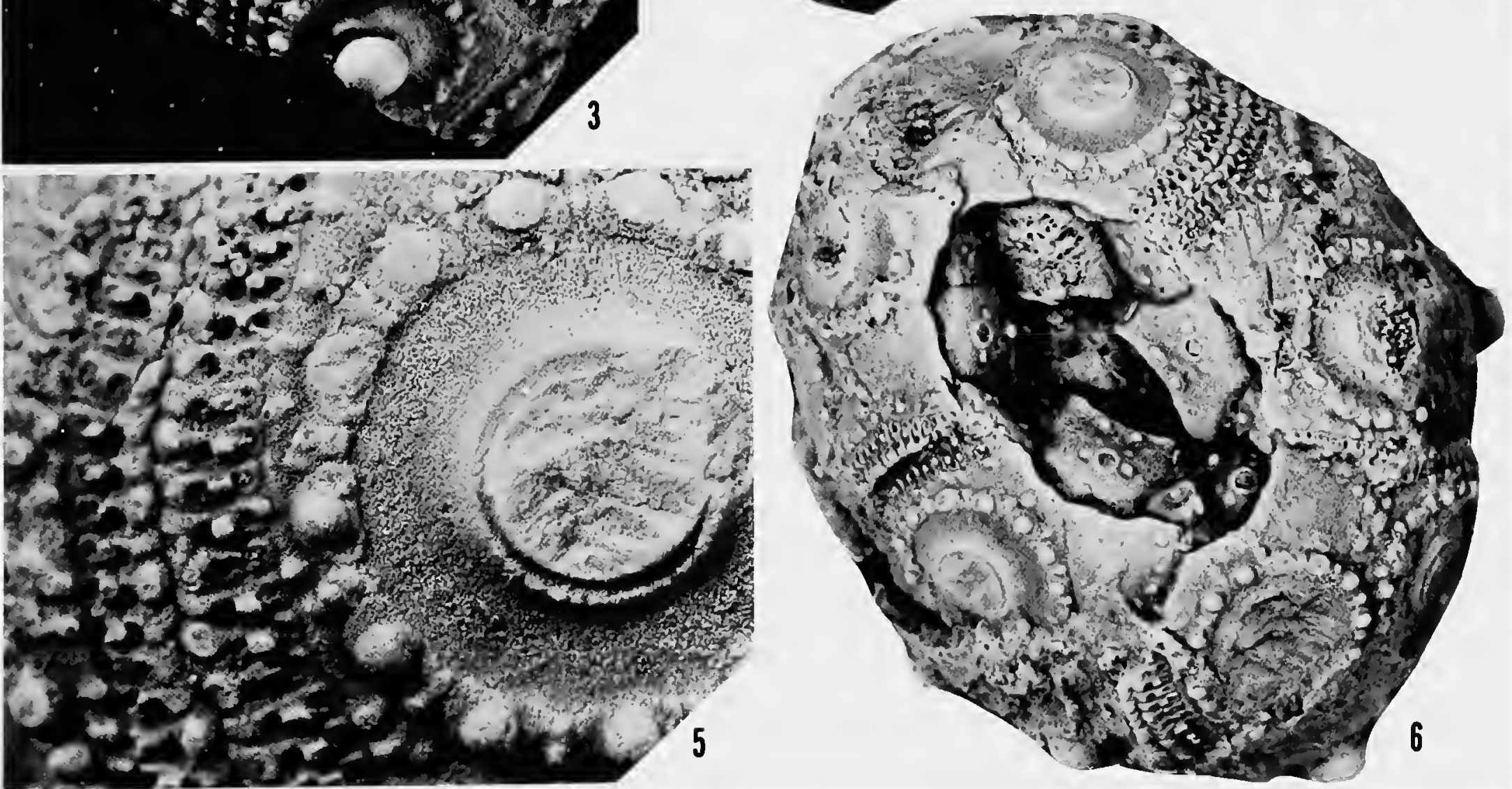


\section{PLATE 5}

\section{Triadocidaris subsimilis (Münster)}

1. Exterior and interior of fragment of an interambulacrum. Laube's (1865a, pl. 9: figs. la, b) figured specimen 4478, in GB, $\times 10$. Late Triassic, early Karnian. St. Cassian Beds, Italy.

\section{Triadocidaris suessii (Laube)}

2. Paralectotype $4483 b$, in GB, $\times 4$. Late Triassic, early Karnian, St. Cassian Beds, Italy.

3. Lectotype, $4483 \mathrm{a}, \times 4$.

4. Enlarged view of adapical portion of 4483 a showing slight crenulations on two of the primary tubercles, $\times 8$.

\section{Triadocidaris venusla (Münster)}

5, 6. Side views of the holotype, AS VII 436, in BSPG, specimen photographed immersed in xylene, $\times 16$. Late Triassic, early Karnian, St. Cassian Bcds, Italy.

7 , 8. Adapical and adoral views of the same specimen, $\times 16$. 

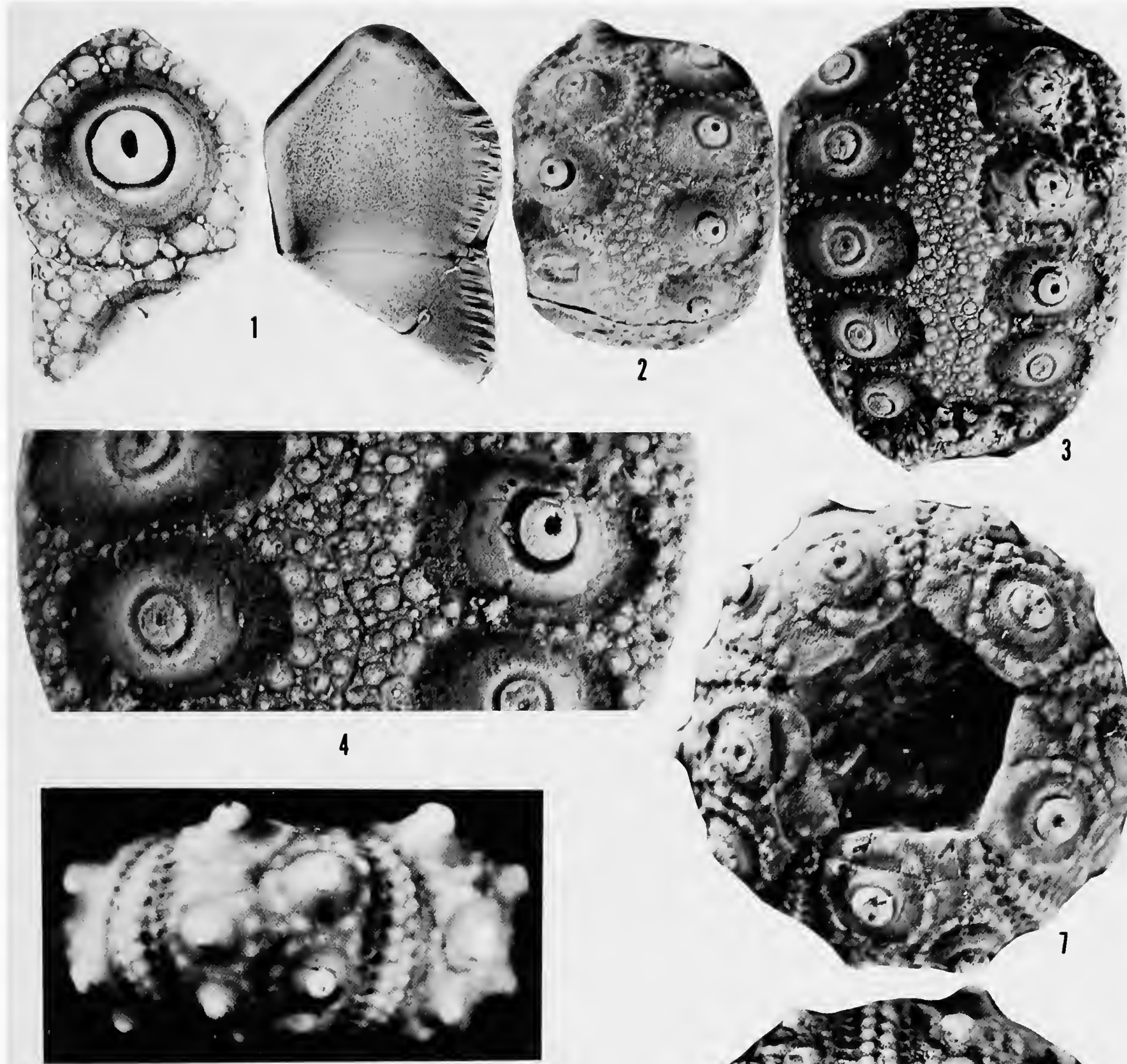

5

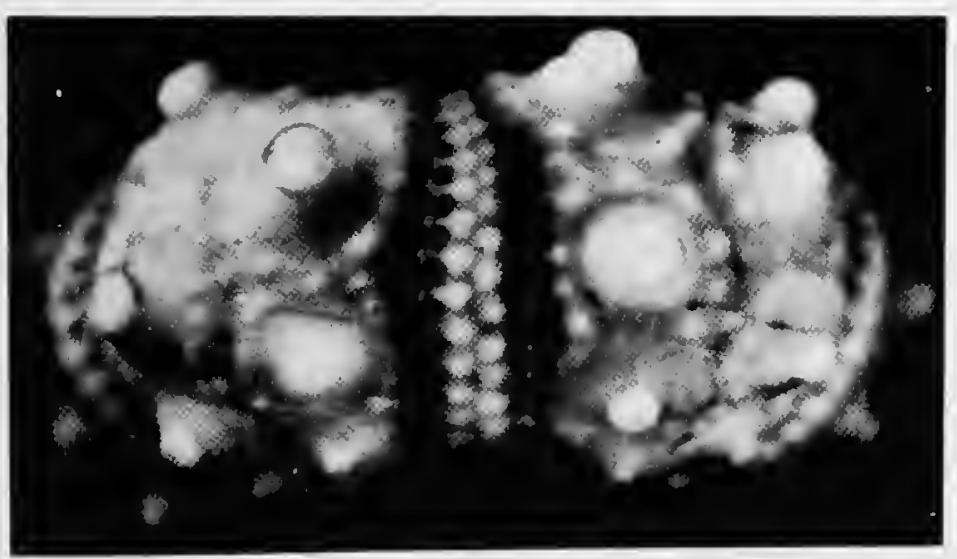

Q1) $-4+20+4=$

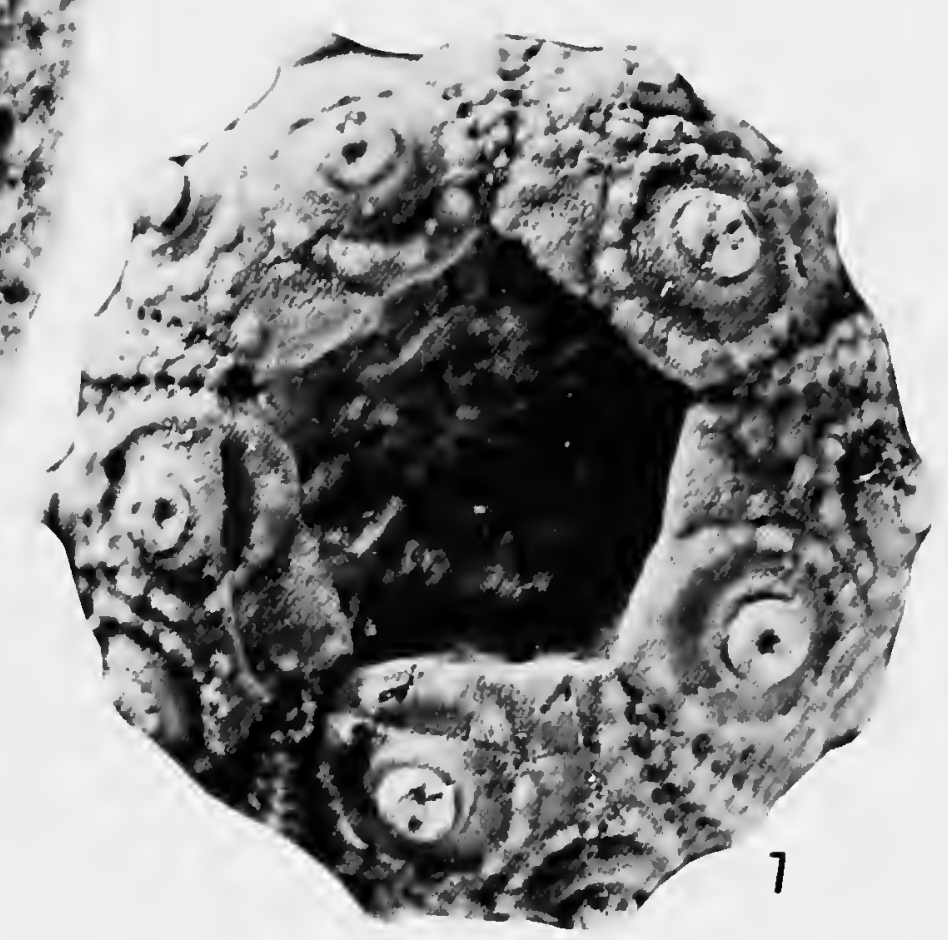
s.t.

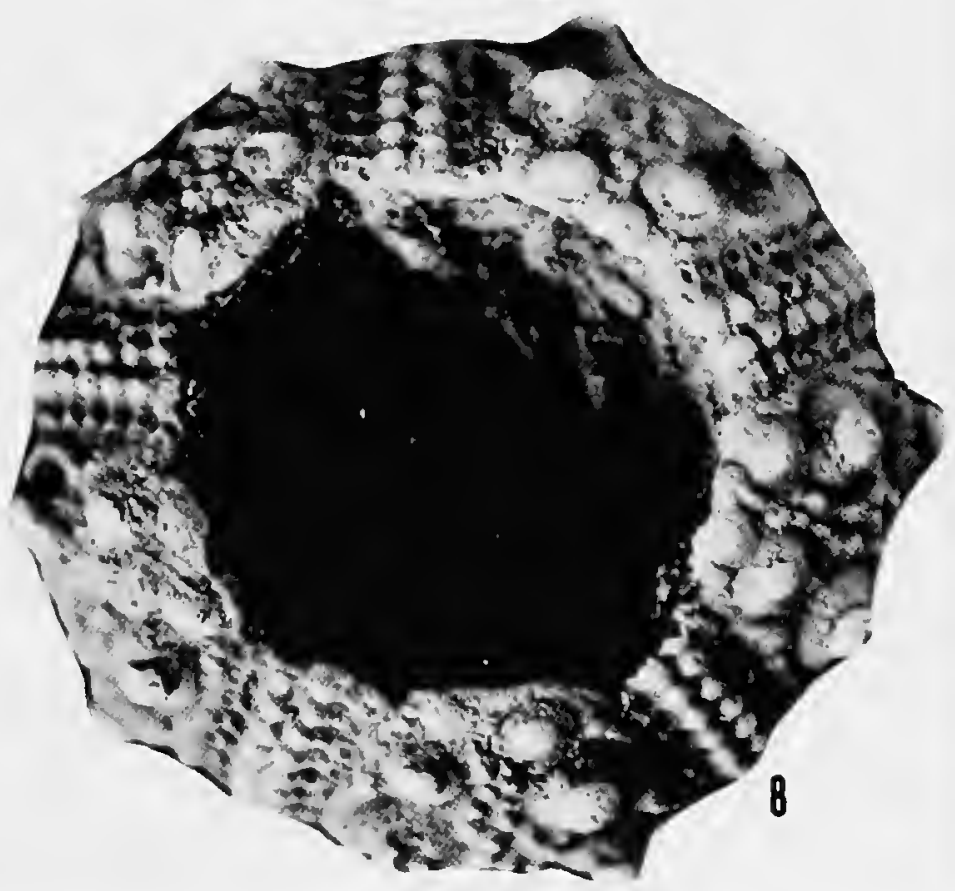




\section{PLATE 6}

\section{Triadocidaris cf. T. venusta (Münster)}

1, 2, 3. Adapical, side, adoral views of Zardini's (1973a: pl. 6: figs. 6a-b) figured specimen 164$S-Z$, in MCA, $\times 20$. Late Triassic, early Karnian, St. Cassian Beds, Alpe di Specie. Collector: Zardini.

$4,5,6$. Adapical, side, adoral view's of 2733-S-Z, in MCA, $\times 12$. Same occurrence and collector as above.

7, 8, 9. Adapical, side, adoral views of $174-\mathrm{M}-Z$, in MCA, $\times 10$. Triassic, early Karnian, St. Cassian Beds, Milieres. Collector: Zardini. 

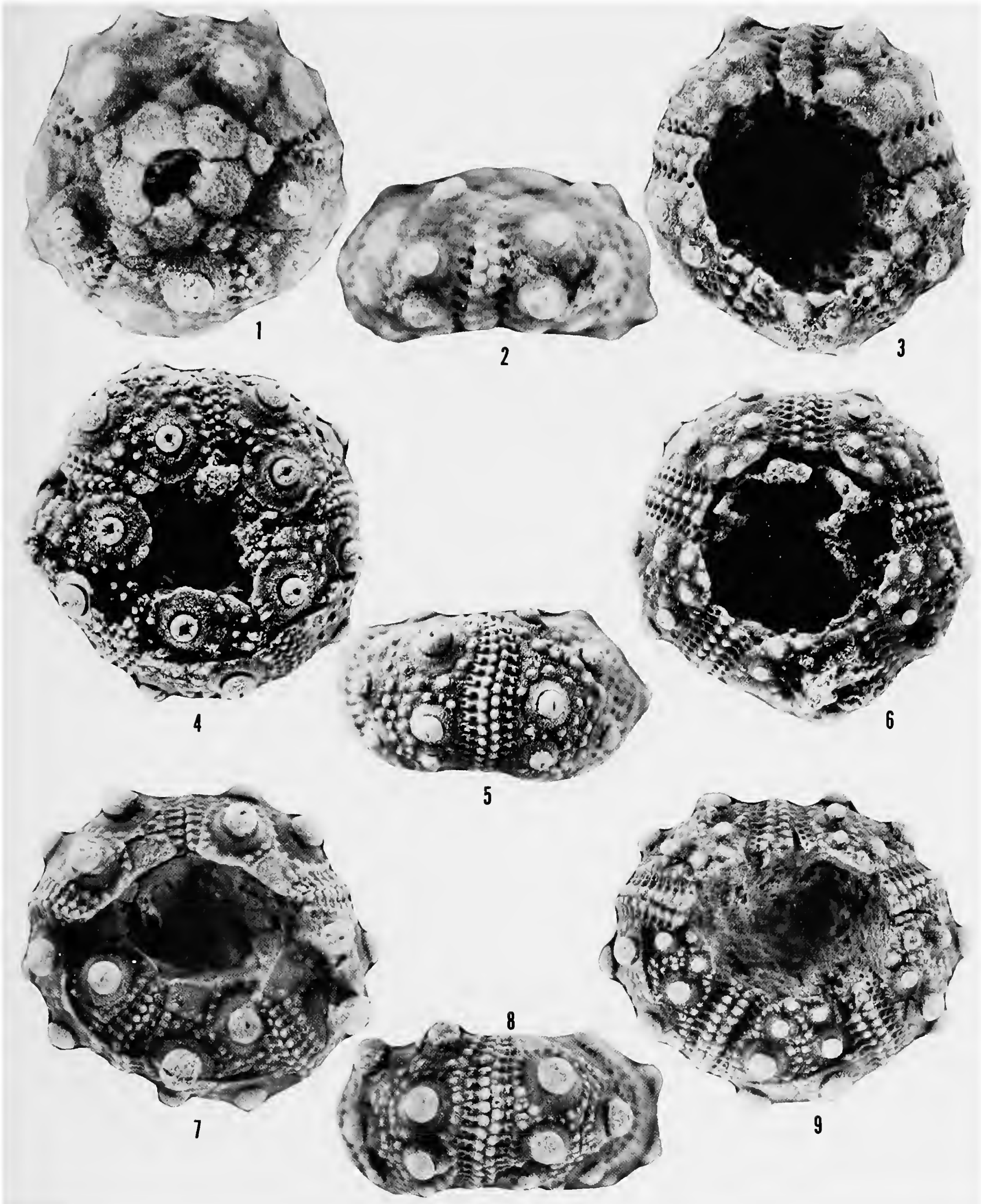


\section{PLATE 7}

Triadocidaris cf. T. venusla (Münster)

1, 2, 3. Adapical, side, adoral views of Zardini's (1973a: pl. 5: figs. 26a-e) figured specimen 173-T-ZG, in MCA, $\times$ 8. Late Triassic, early Karnian, St. Cassian Beds, Tamarin. Collector: Zardini Giorgio.

4, 5, 6. Adapical, side, adoral views of 2731-S-Z, in MCA, X 7. Late Triassic, early Karnian, St. Cassian Beds, Alpe di Specie. Collector: Zardini.

Cidaris gerana Braun

7, 8, 9. Adapical, side, adoral views of the holotype, AS VII 434, in BSPG, $\times 12$. Late Triassic, early Karnian, St. Cassian Beds. Italy. 

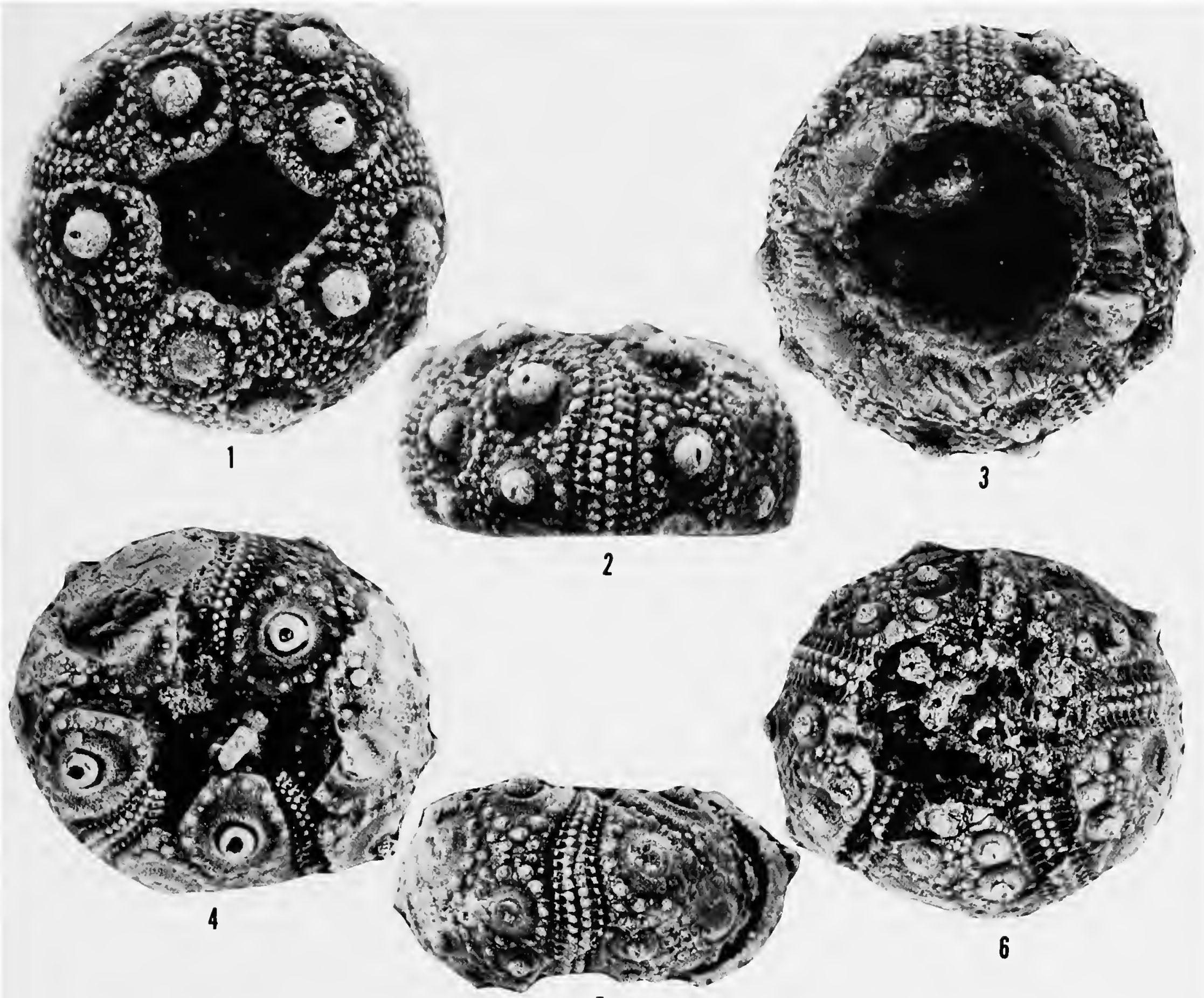

5
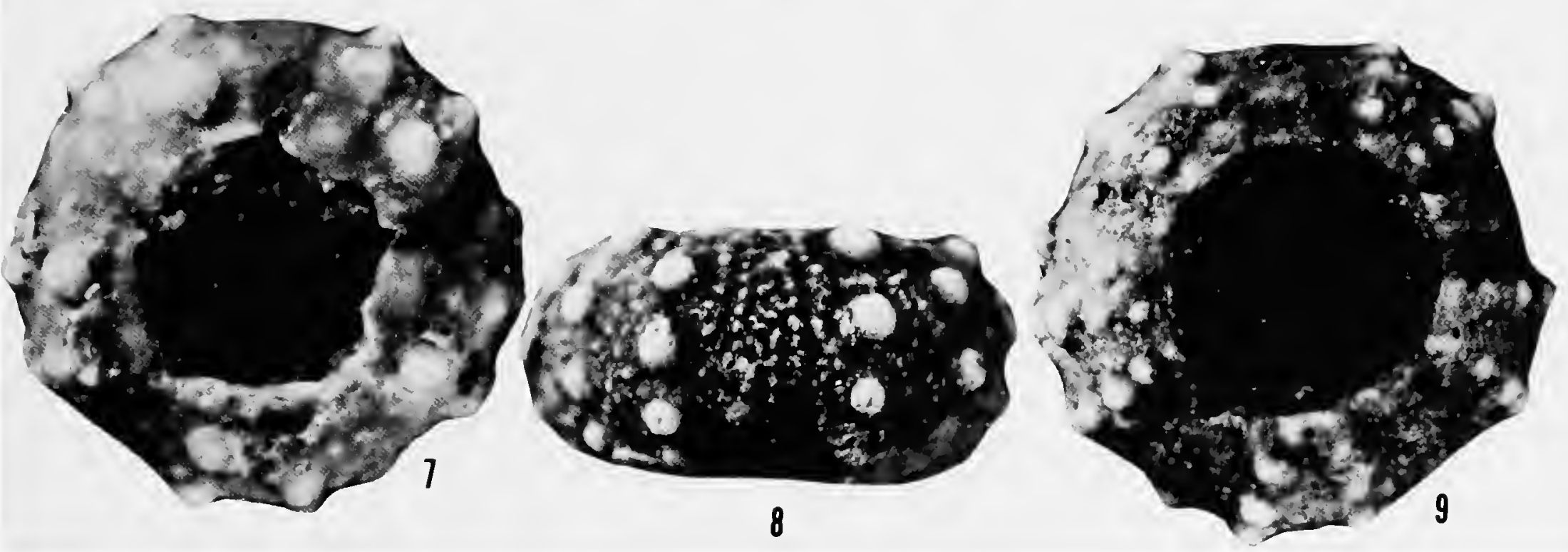


\title{
PLATE 8
}

\author{
Triadocidaris giauensis (Zardini)
}

1. Side view of holotype, 163-G-Z, in MCA, $\times$ 4. Late Triassic, early Karnian, St. Cassian Beds, Forcella Giau. Collector: Zardini.

2. Adapical area of ambulacrum of same specimen, $\times 7$.

$$
\text { Polycidaris regularis (Münster) }
$$

3, 4, 5. Adapical, adoral, side views of the holotype AS VII 435, in BSPG, $\times 2$. Specimen photographed immersed in xylene. Late Triassic, early Karnian, St. Cassian Beds, Italy.

6. View of interambulacrum of the same specimen, $\times 5$. 

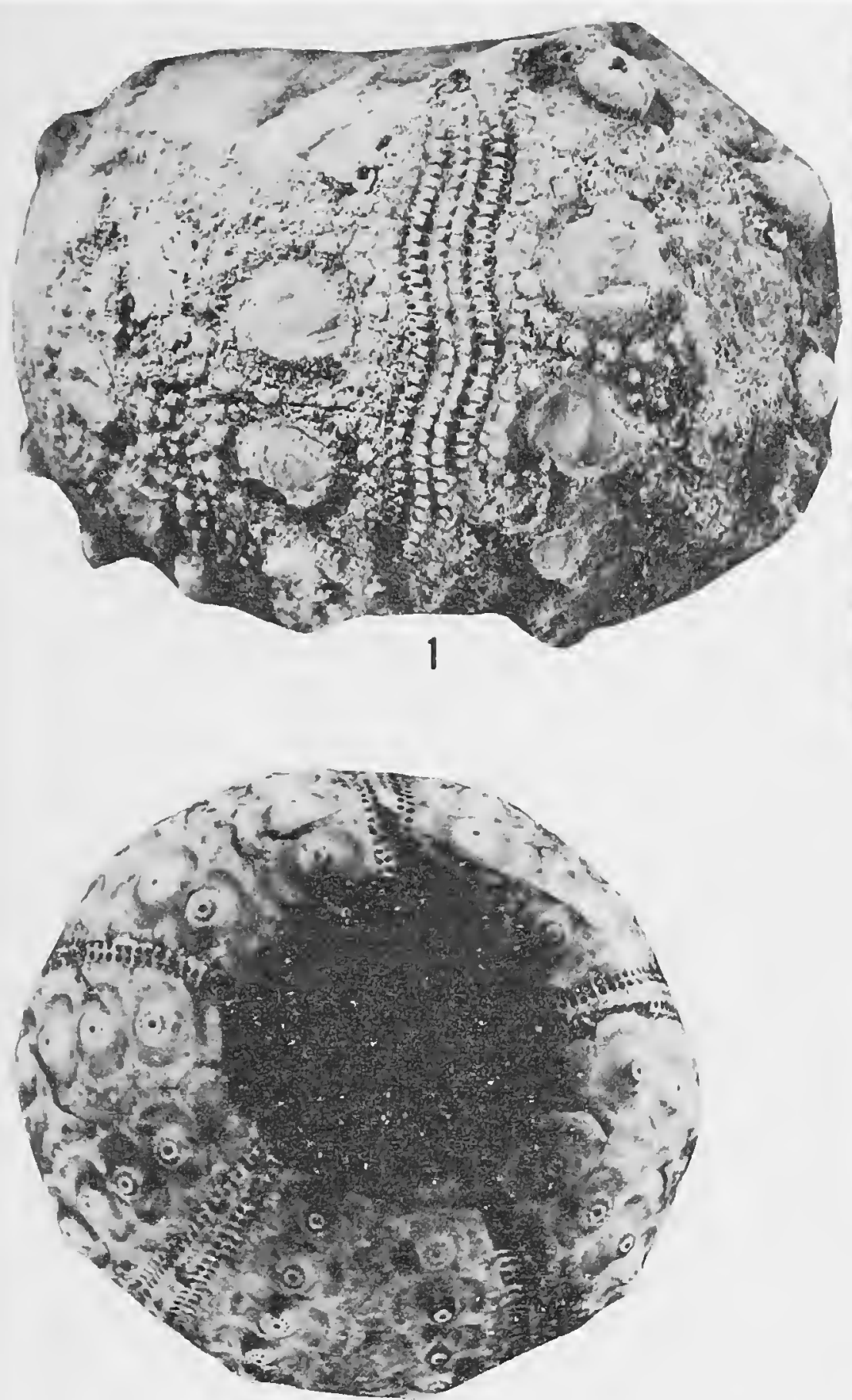

3

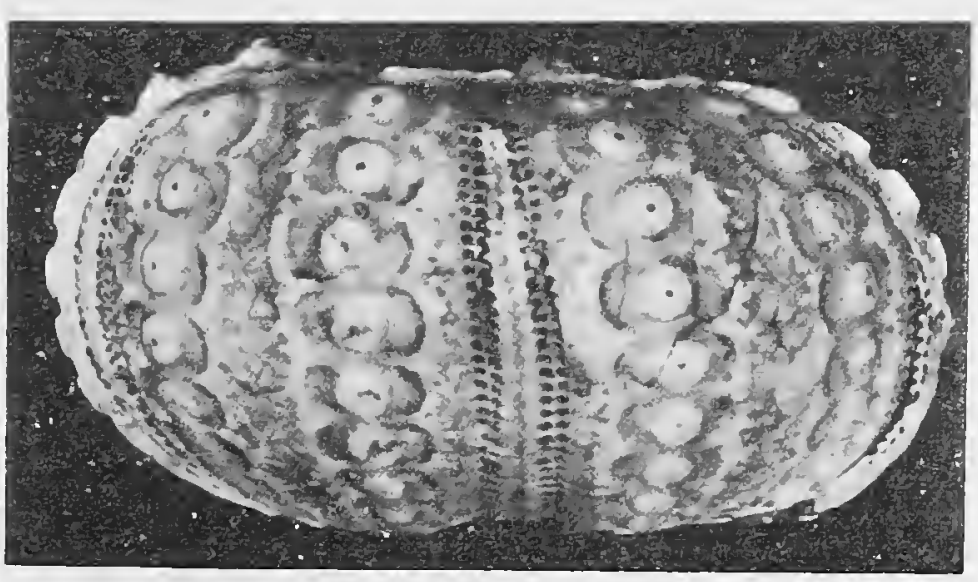

5
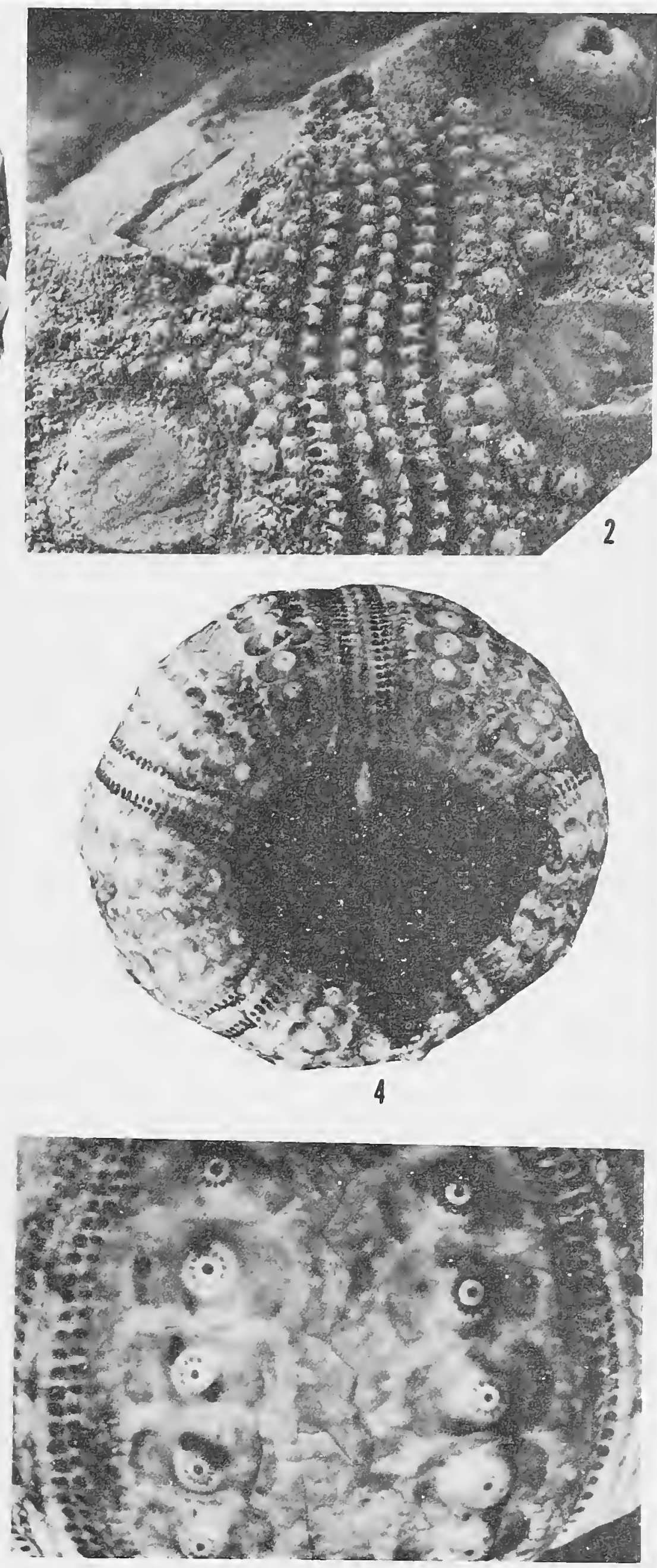


\section{PLATE 9}

\section{Zardinechinus lancedelli (Zardini)}

I, 2, 3, 4. Adapical, two side views, and one adoral view of Zardini's (1973a: pl. 5: fig. 24) holotype 172-Mi-L, in MCA, × 7.5. Late Triassic, early Karnian, St. Cassian Beds, Milieres. Collector: Lancedelli.

5. Ambulacrum adapical to the ambitus of the same specimen, $\times 30$.

6. Interambulacrum of the same specimen, $\times 17$. 

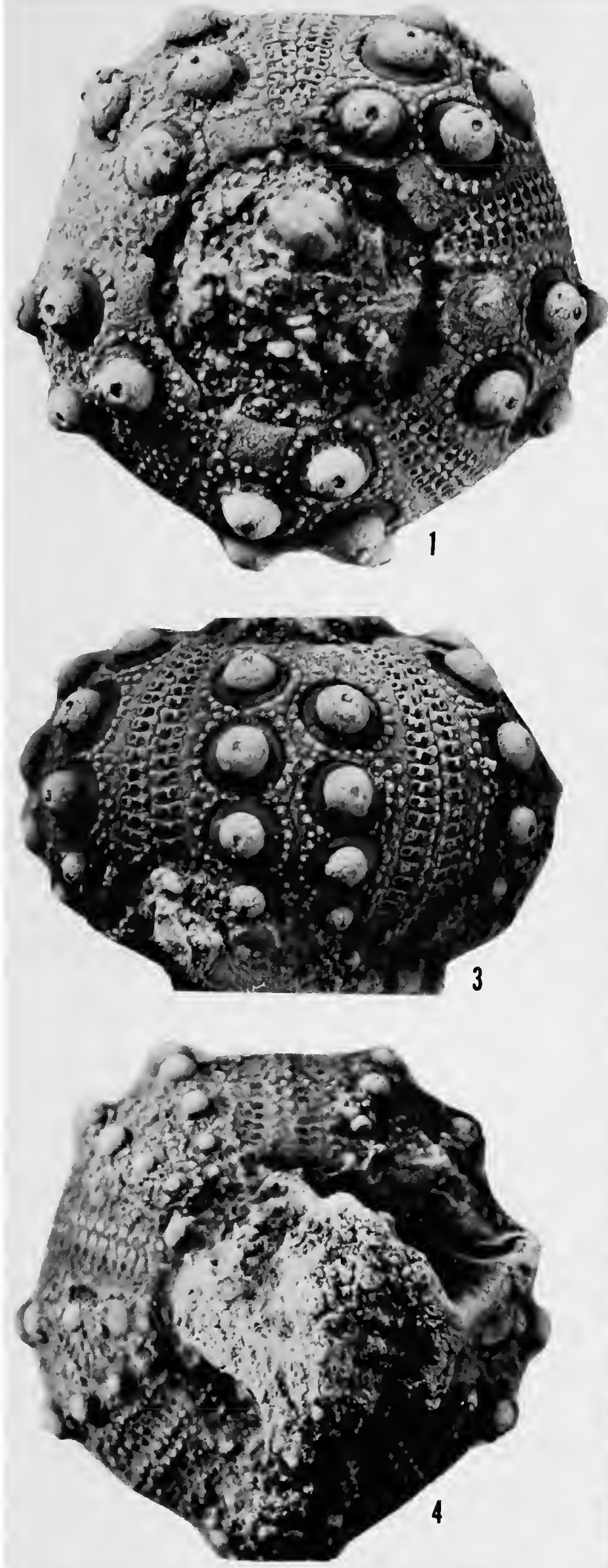
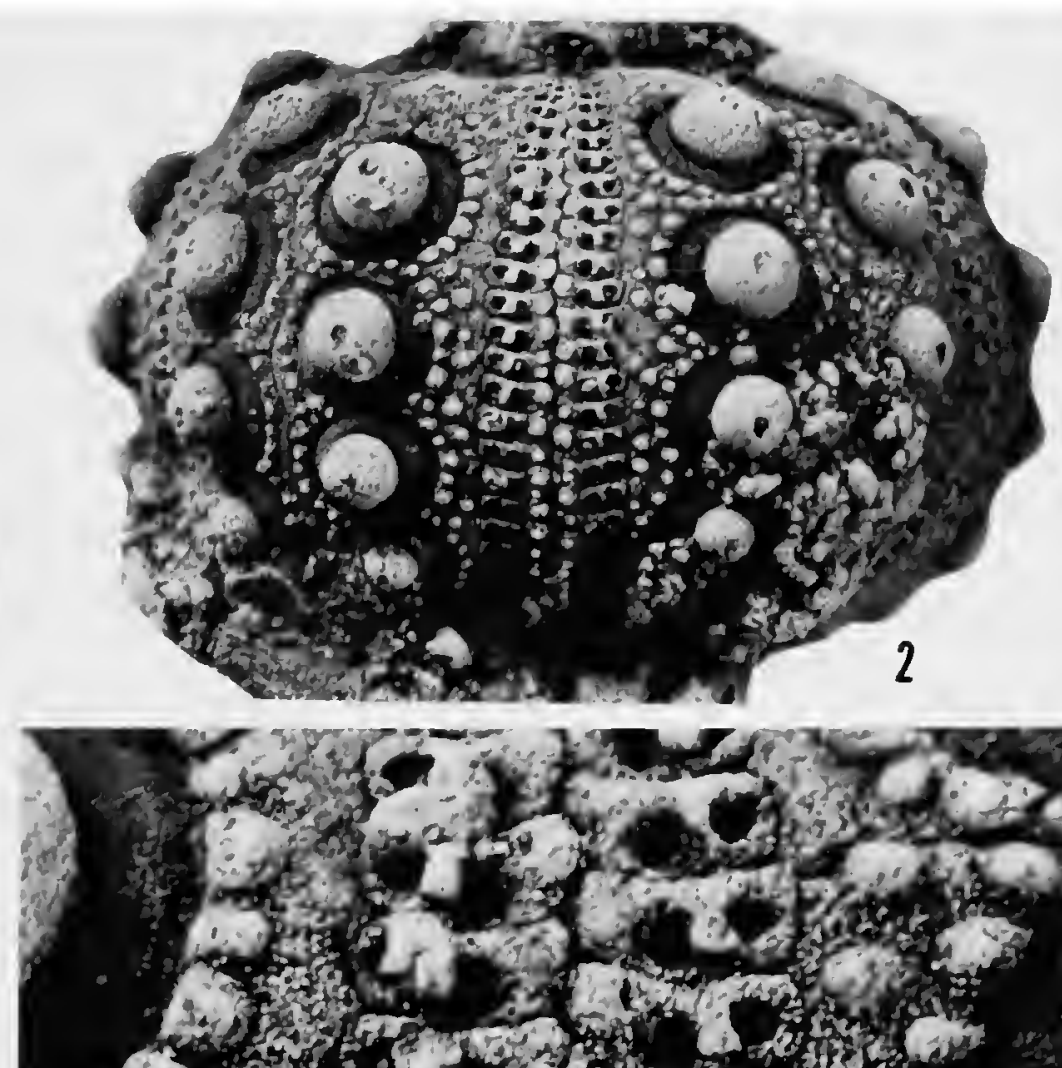

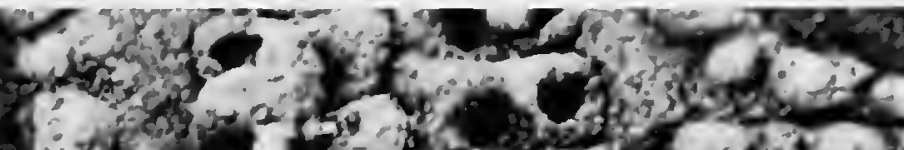

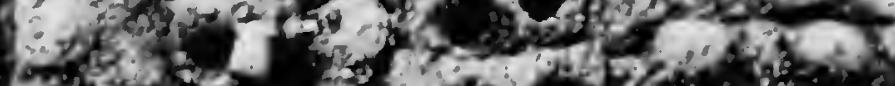

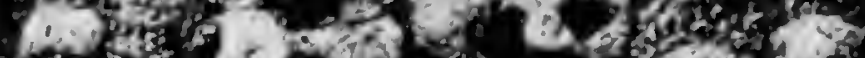

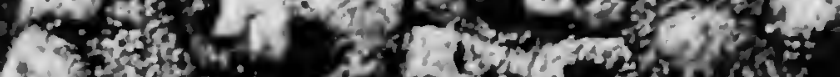

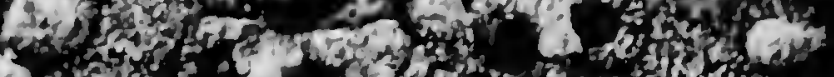

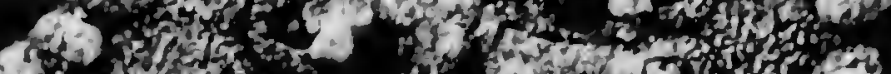

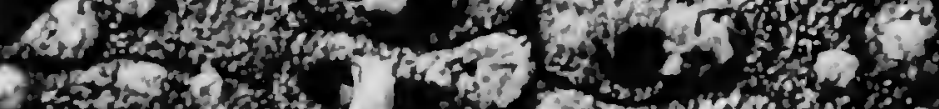

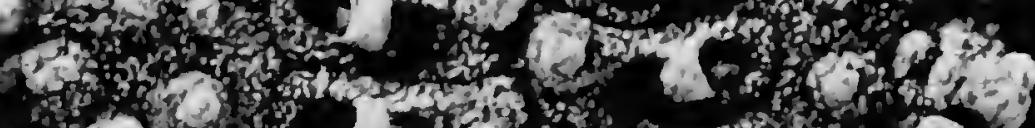

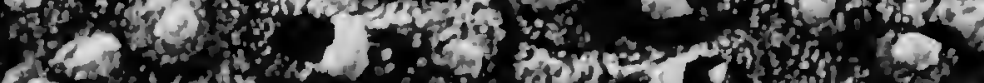

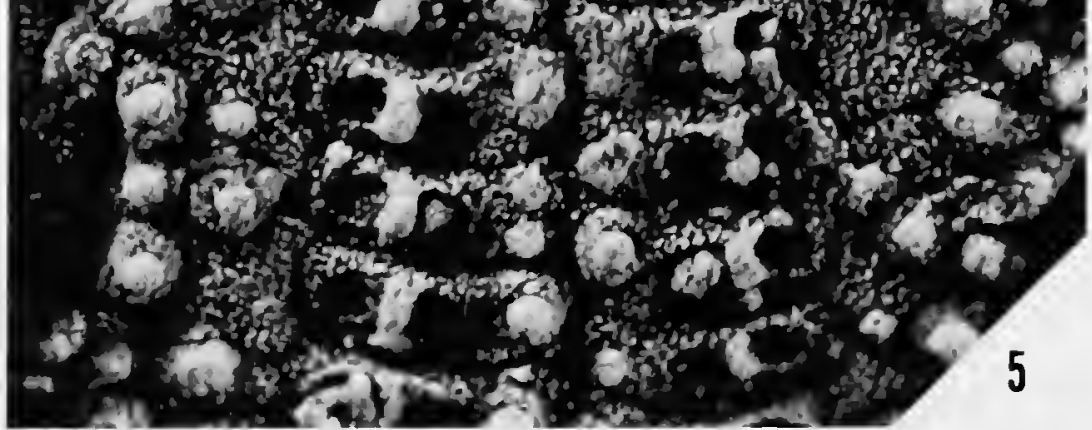

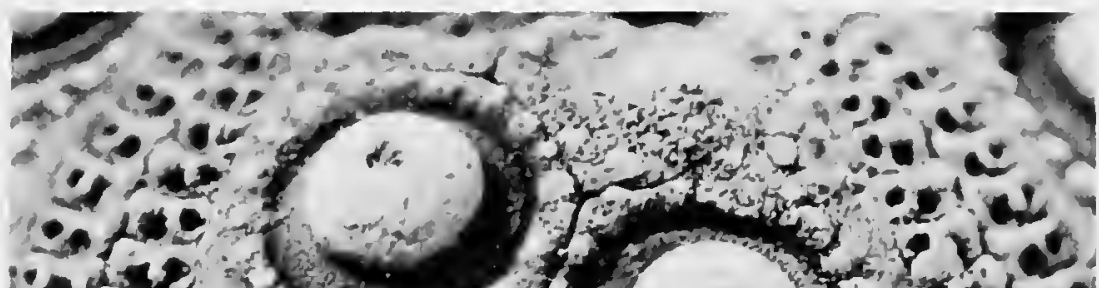

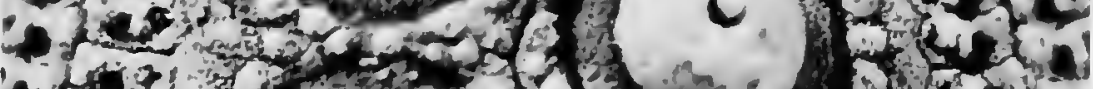

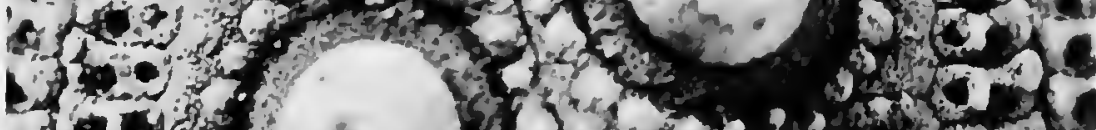

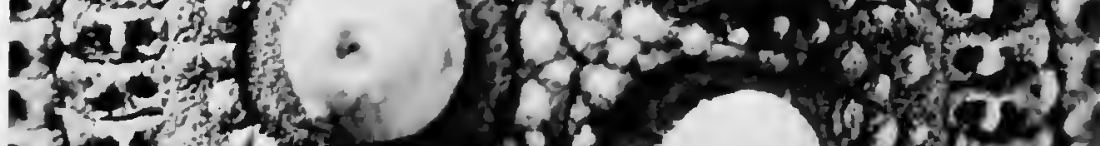

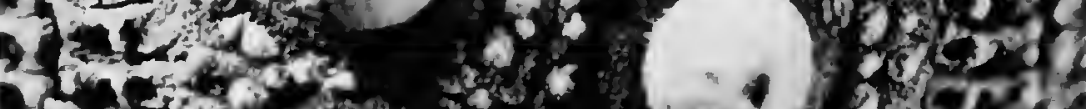

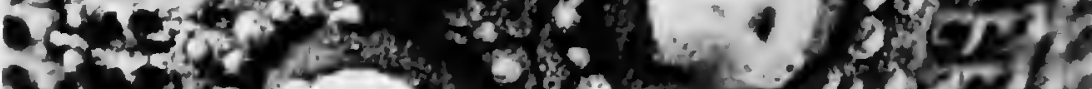

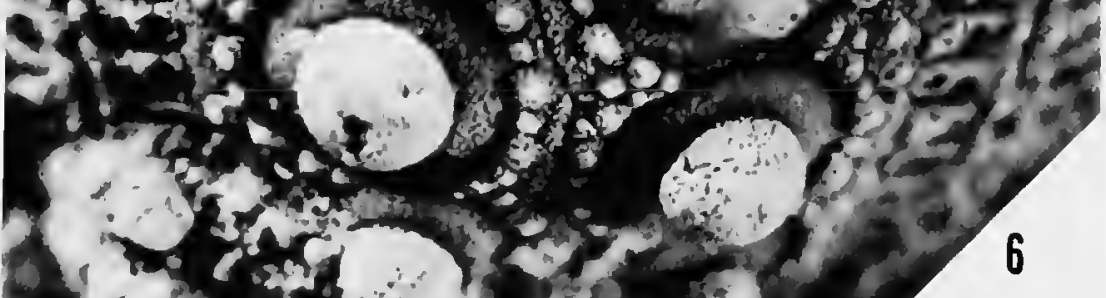




\section{PLATE 10}

\section{Zardinechinus lancedelli (Zardini)}

1. Ambitus of specimen $3135-C-Z$, in MCA, $\times 9$. This specimen shows the portion of the ambulacra which is covered and beveled over by the adjacent interambulacra when these plates are in place. Late Triassic, early Karnian, St. Cassian Beds, Campo. Collector: Zardini.

2, 3. Exterior and interior of adoral portion of ambulacrum removed from the specimen figured above, $\times 12$. Note the presence of auricles on the interior at the adoral border.

4. Adapical and ambitus of interambulacrum of typical specimen, 3136-C-Z, in MCA, $\times 10$. Late Triassic, early Karnian, St. Cassian Beds, Campo. Collector: Zardini.

5, 6. Exterior and interior view of interambulacrum of specimen, 3137-C-Z, in MCA, $\times 9$. Note on the interior the deep longitudinal groove along the medial suture and thickening of the plates on the transverse sutures. Late Triassic, early Karnian, St. Cassian Beds, Campo. Collector: Zardini.

7. Interambulacrum of specimen, 3138-C-Z, in MCA. $\times 10$. Late Triassic, early Karnian, St. Cassian Beds, Campo. Collector: Zardini.

8. Interambulacrum of specimen, 3139-C-Z, in MCA, $\times 10$. This specimen differs from the typical in having its tubercles with slit-like perforations, and a broader field of secondary tubercles along the medial interradial suture. Late Triassic, early Karnian, St. Cassian Beds, Campo. Collector: Zardini.

9. Interambulacrum of specimen, 3140-C-Z, in MCA, $\times 11$. This specimen is intermediate in that although it has slit-like perforations and a few crenulations, it has a narrow field of secondary tubercles along the medial and interradial suture. Late Triassic, early Karnian, St. Cassian Beds, Campo. Collector: Zardini. 


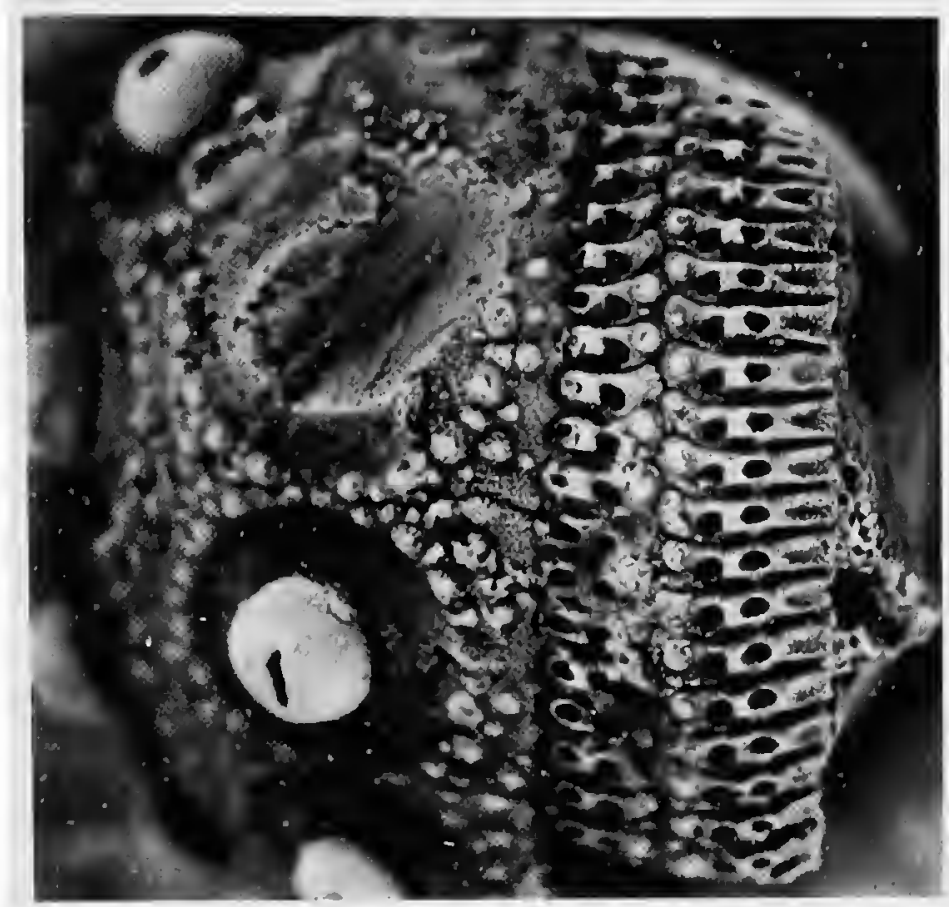

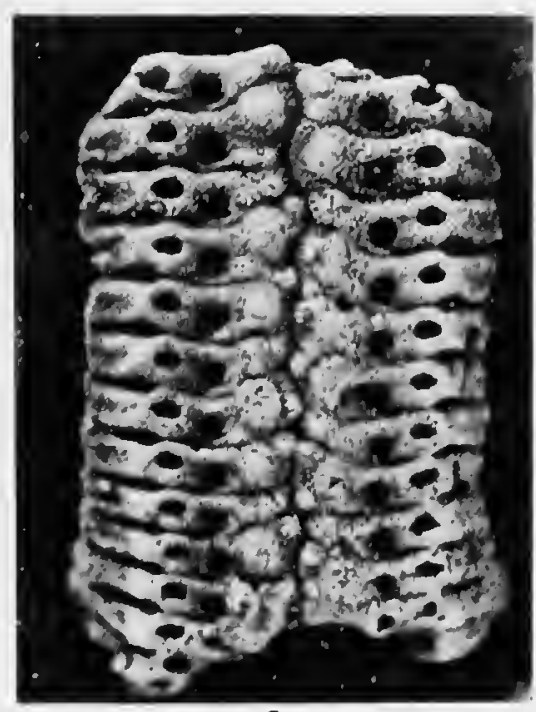

2
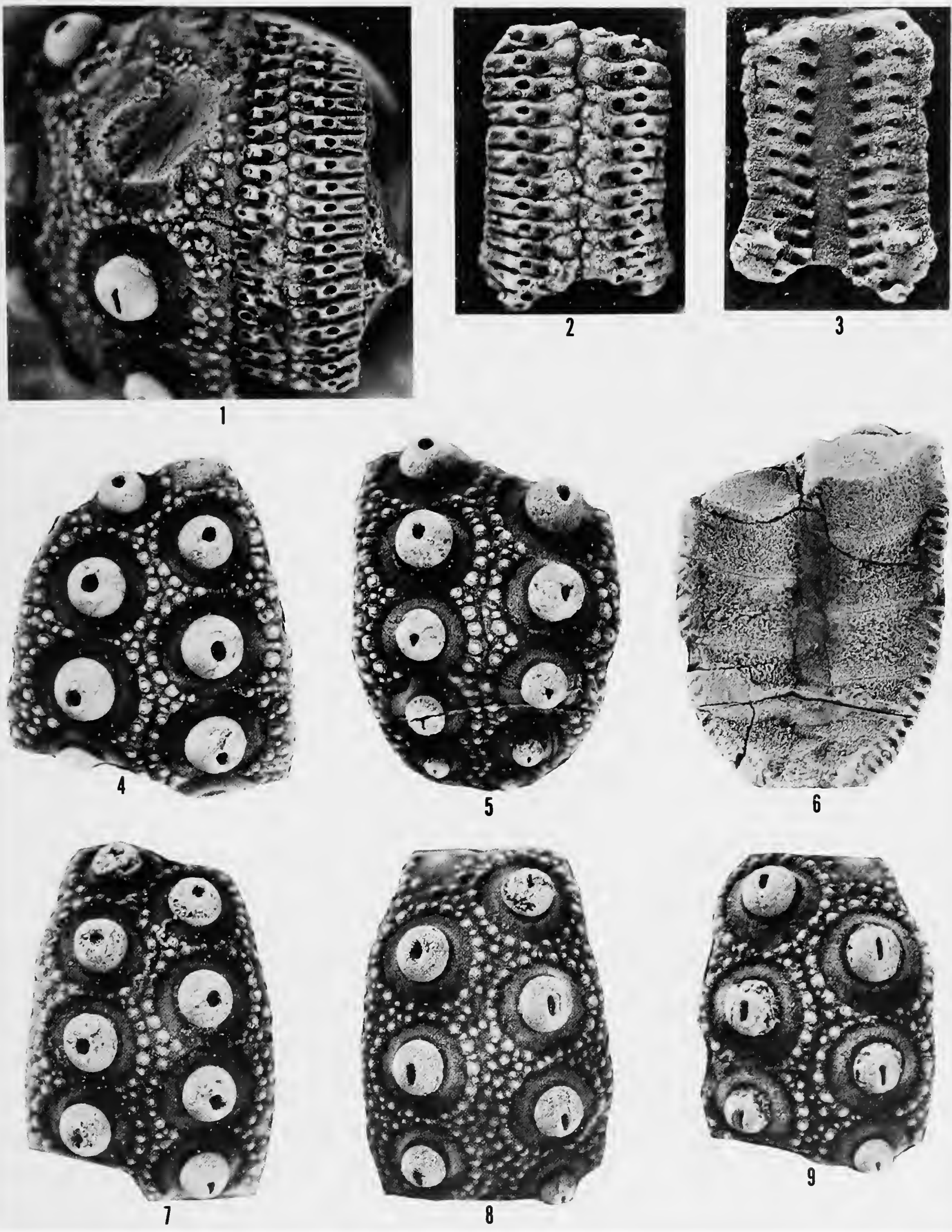


\section{PLATE 11}

\section{Zardinechinus lancedelli (Zardini)}

1, 2, 3, 4. Adapical, adoral side views of Zardini's (1973a: pl. 6: figs. 1la, b) figured specimen 1901-S-Z, in MCA, $\times$ 5. Late Triassic, early Karnian, St. Cassian Beds, Alpe di Specie. Collector: Zardini.

5, 6, 7, 8. Adapical, side, adoral views of Zardini's (1973a: pl. 5: figs. 34a, b) figured specimen 152-CZ-L, in MCA, $\times$ 8. Late Triassic, early Karnian, St. Cassian Beds, Cianzopé. Collector: Lancedelli.

Paurocidaris rinbianchi (Zardini)

9, 10. Adapical, adoral views of Zardini's (1973a: pl. 5: figs. la, b) holotype 125-M-Z, in MCA, $\times$ 8. Late Triassic, early Karnian, St. Cassian Beds, Misurina. Collector: Zardini. 

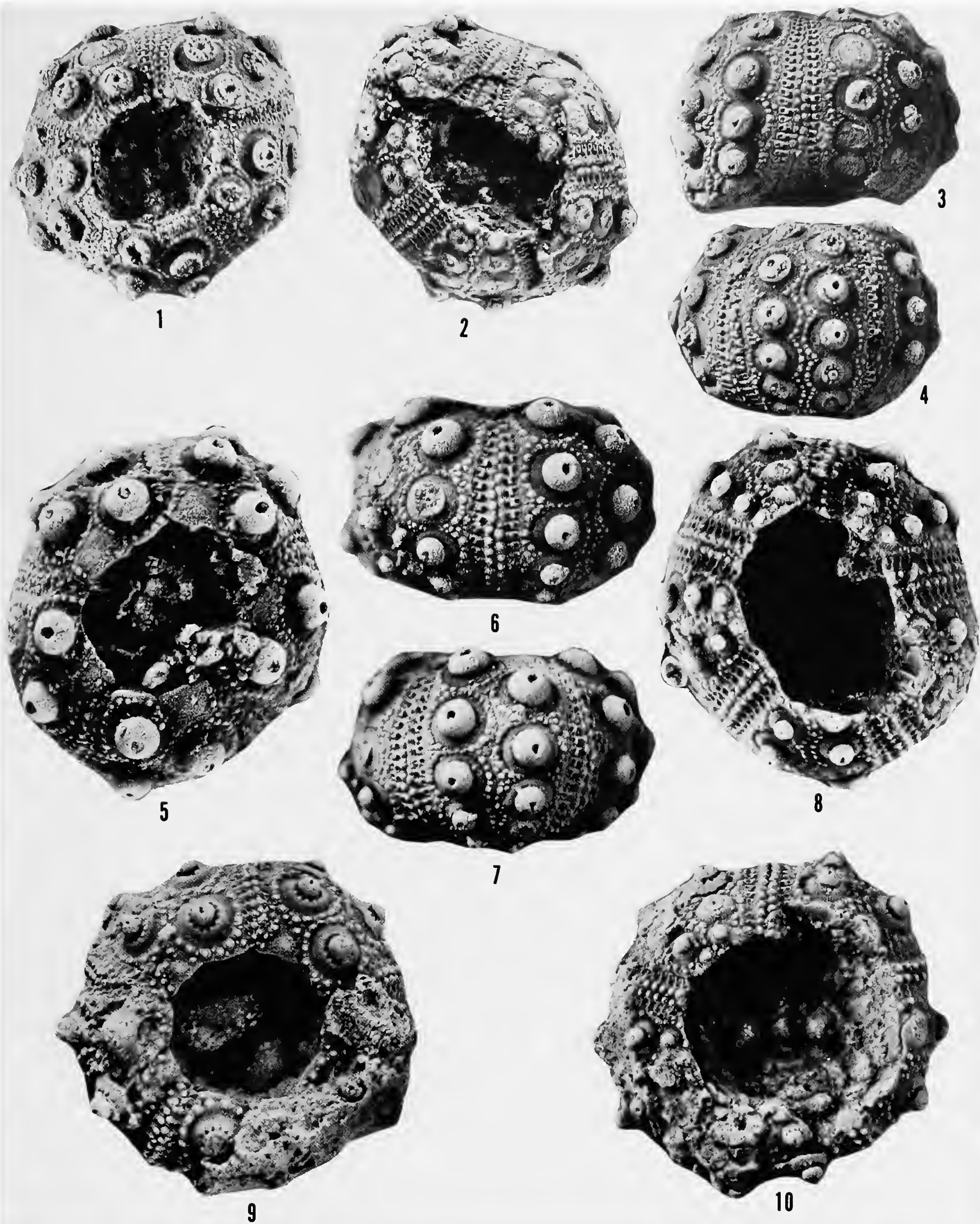


\section{PLATE 12}

Paurocidaris rinbianchi (Zardini)

1,2. Side views of the holotype figured on Plate 11: figures 9-10, $\times 16$.

3, 4. Adapical and side views of Zardini's (1973a, pl. 5, figs. 2a, b) figured specimen 127-S-Z, in MCA, $\times$ 20. Late Triassic, early Karnian, St. Cassian Beds, Alpe di Specie. Collector: Zardini.

\section{Species uncertain}

5. Side view of Zardini's (1973a, pl. 6: fig. 12) figured paratype that he referred to Cidaris rinbianchi but does not appear to belong to this species, 126-C-L, in MCA, $\times 12$. Late Triassic, early Karnian, St. Cassian Beds, Campo. Collector: Lancedelli.

\section{Leurocidaris montanaro (Zardini)}

6. Side view of the holotype, 140-S-Z, in MCA, $\times 15$. Late Triassic, early Karnian, St. Cassian Beds, Alpe di Specie. Collector: Zardini.

7. Adapical view of same specimen showing the perforation in an adapical tubercle, $\times 20$. 

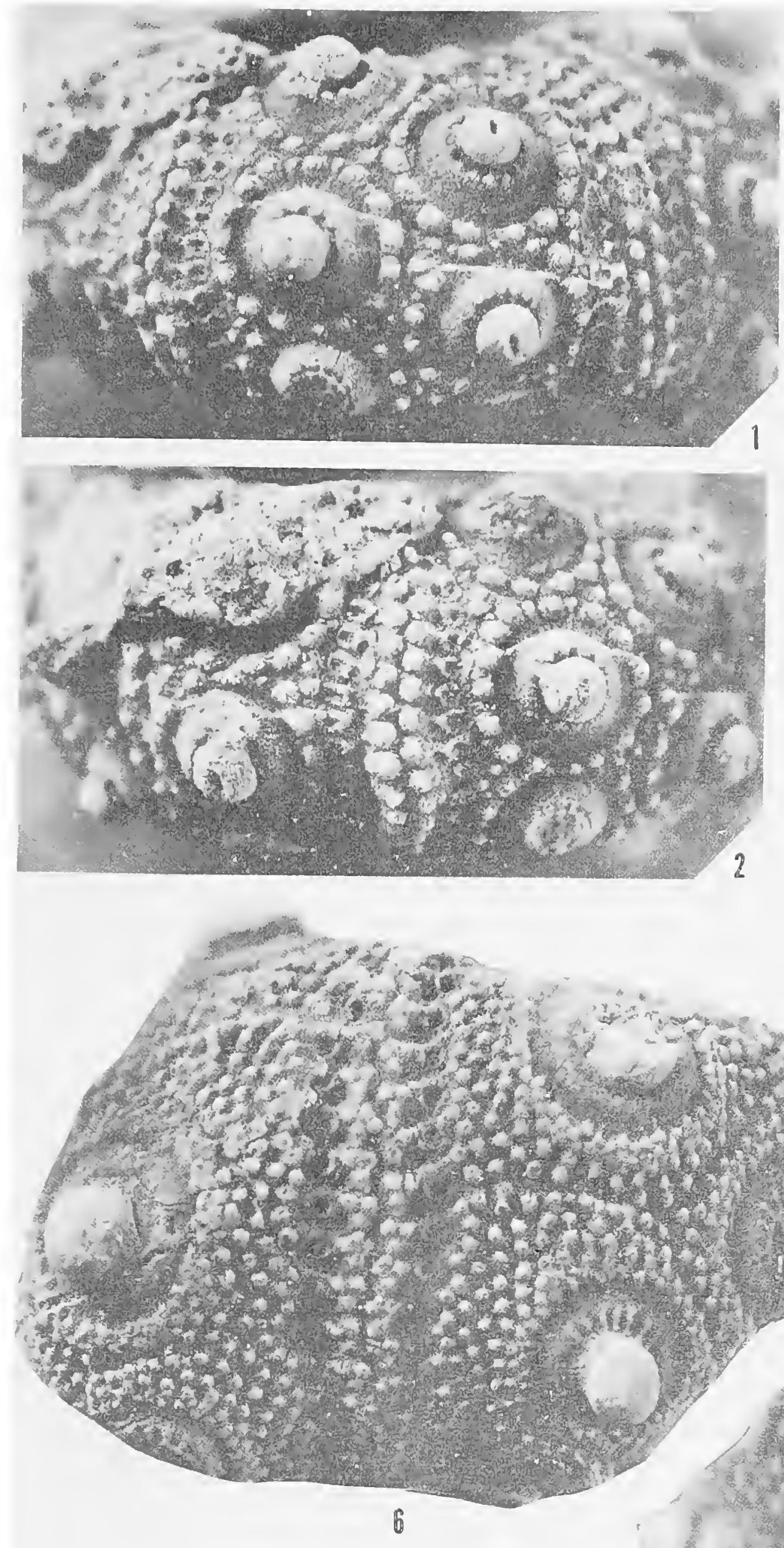
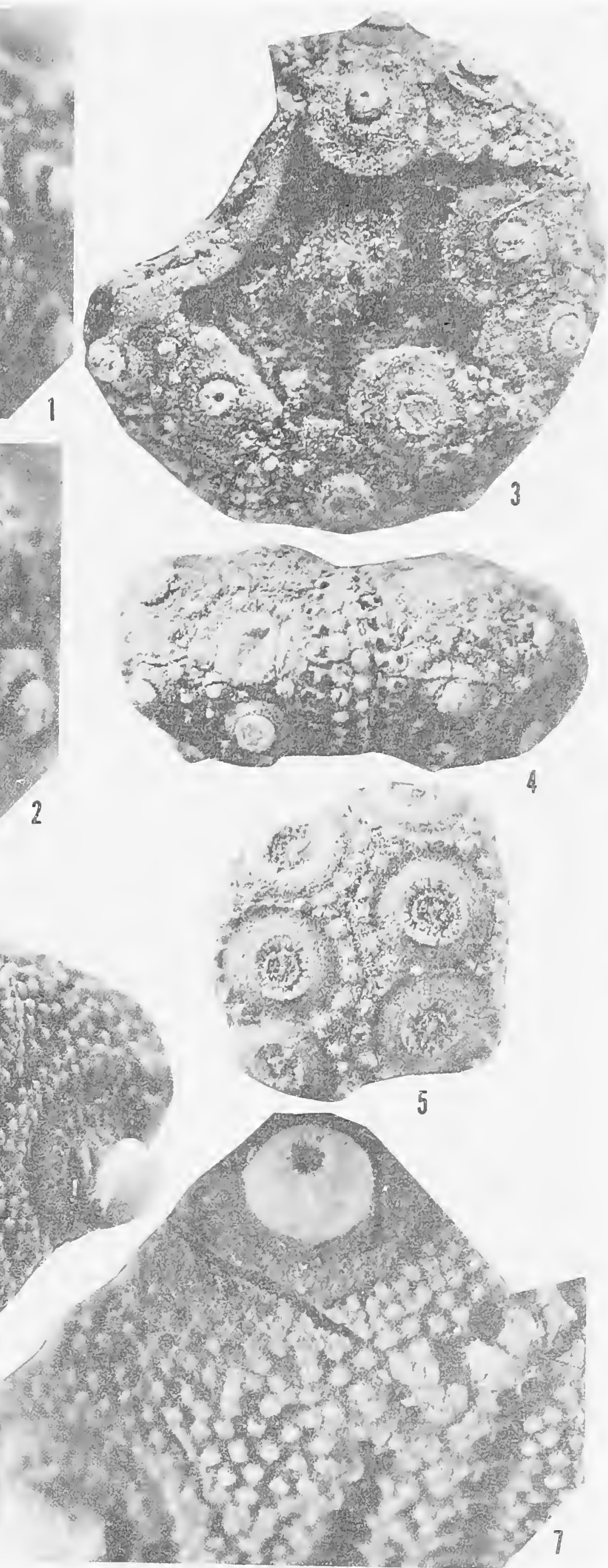


\section{PLATE 13}

\section{Leurocidaris montanaro (Zardini)}

1. Side view of Zardini's (1973a: pl. 5: figs. 15a, b) figured paratype 141-S-Z, in MCA, $\times$ 12. Late Triassic, early Karnian, St. Cassian Beds, Alpe di Specie. Collector: Zardini.

2. Side view of an ambulacrum at the midzone of a paratype, 142-Mi-L, in MCA, $\times 16$. Late Triassic, early Karnian, St. Cassian Beds, Milieres. Collector: Lancedelli.

3, 4, 5. Adapical, adoral, side views of $142-\mathrm{Mi}-\mathrm{L}, \times 6$.

$6,7,8$. Exterior, side, and interior views of $3141-\mathrm{Mi}-\mathrm{Z}$, in $\mathrm{MCA}, \times 15$. Note the serrated edge at the adradial suture and the vertical plane of the suture. Late Triassic, early Karnian, St. Cassian Beds, Milieres. Collector: Zardini.

9. Interior view of $3142-\mathrm{S}-\mathrm{Z}$, in $\mathrm{MCA}, \times 11$, showing ridge at edge of peristome presumably a lantern support (apophysis). Late Triassic, early Karnian, St. Cassian Beds, Alpe di Specie. Collector: Zardini. 

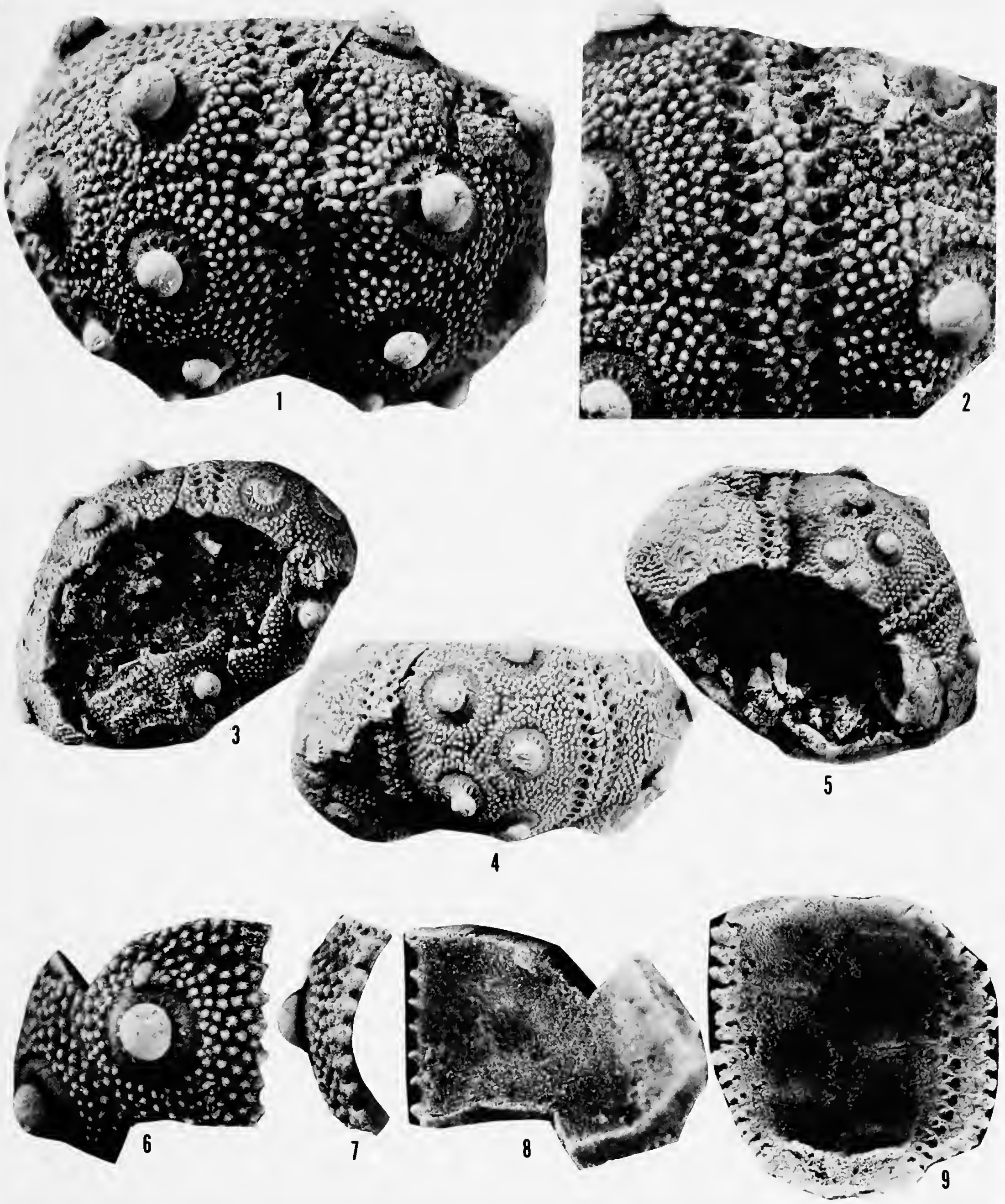


\section{PLATE 14}

\section{Levicidaris zardinia, new species}

$1,2,3,4$. Adapical, adoral, side views of the holotype $148-S-$ So. $-\mathrm{T}$, in MCA, $\times 4$. Late Triassic, early Karnian, St. Cassian Beds, Alpe di Specie. Collector: Sorelle Toscani.

5. Side view of Zardini's (1973a, pl. 5: figs. 28a, b) figured paratype 147-S-L, in MCA $\times$ 4. Late Triassic, early Karnian, St. Cassian Beds, Alpe di Specie. Collector: Lancedelli.

6. Side view of Zardini's (1973a, pl. 5: fig. 33) figured paratype 151-M-Z, in MCA, $\times$ 5. Late Triassic, early Karnian, St. Cassian Beds, Misurina. Collector: Zardini.

7. 8. Adapical and midzone views of ambulacrum of the holotype, $\times 15, \times 11$. (See Plate 15 for adoral view.) 

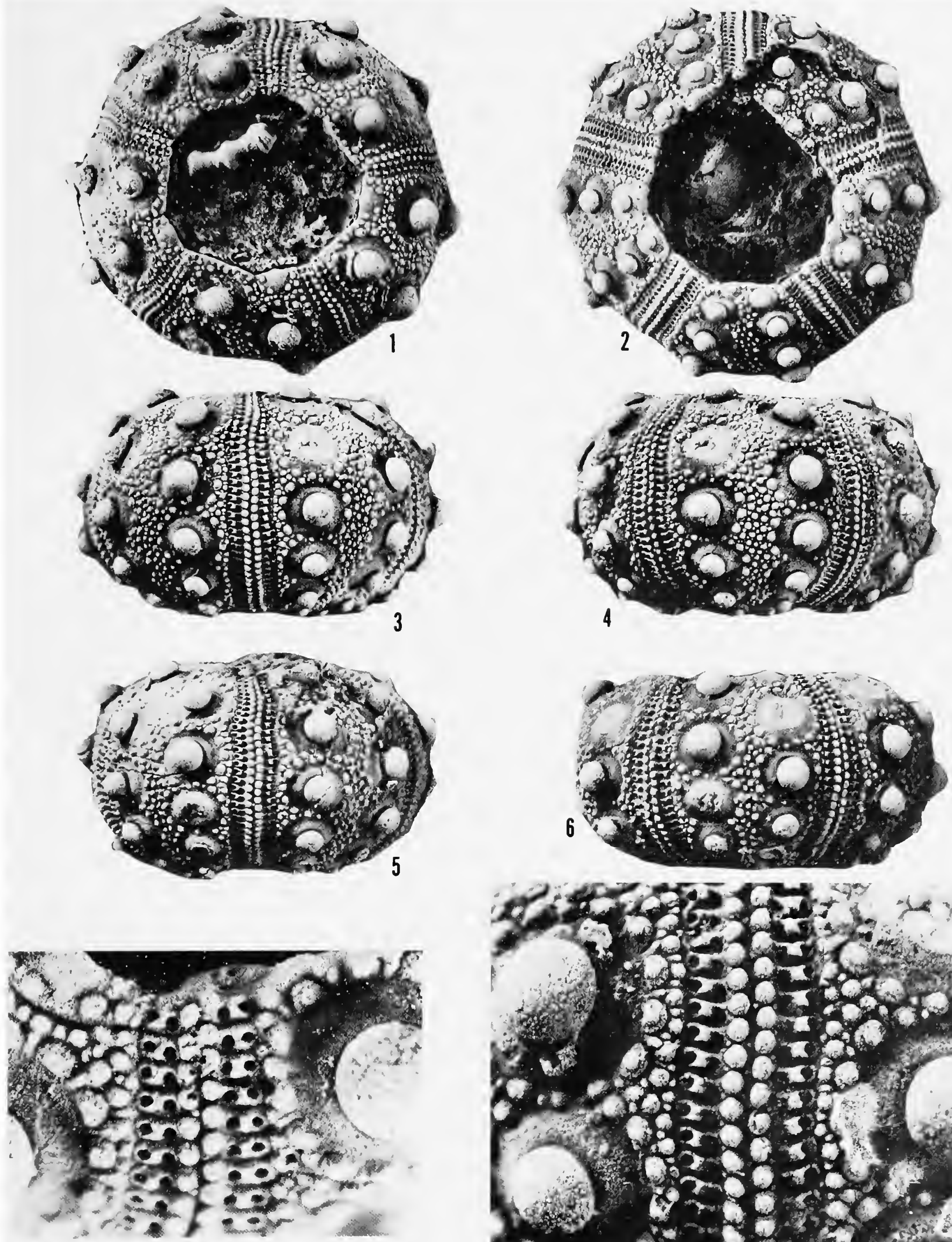

7

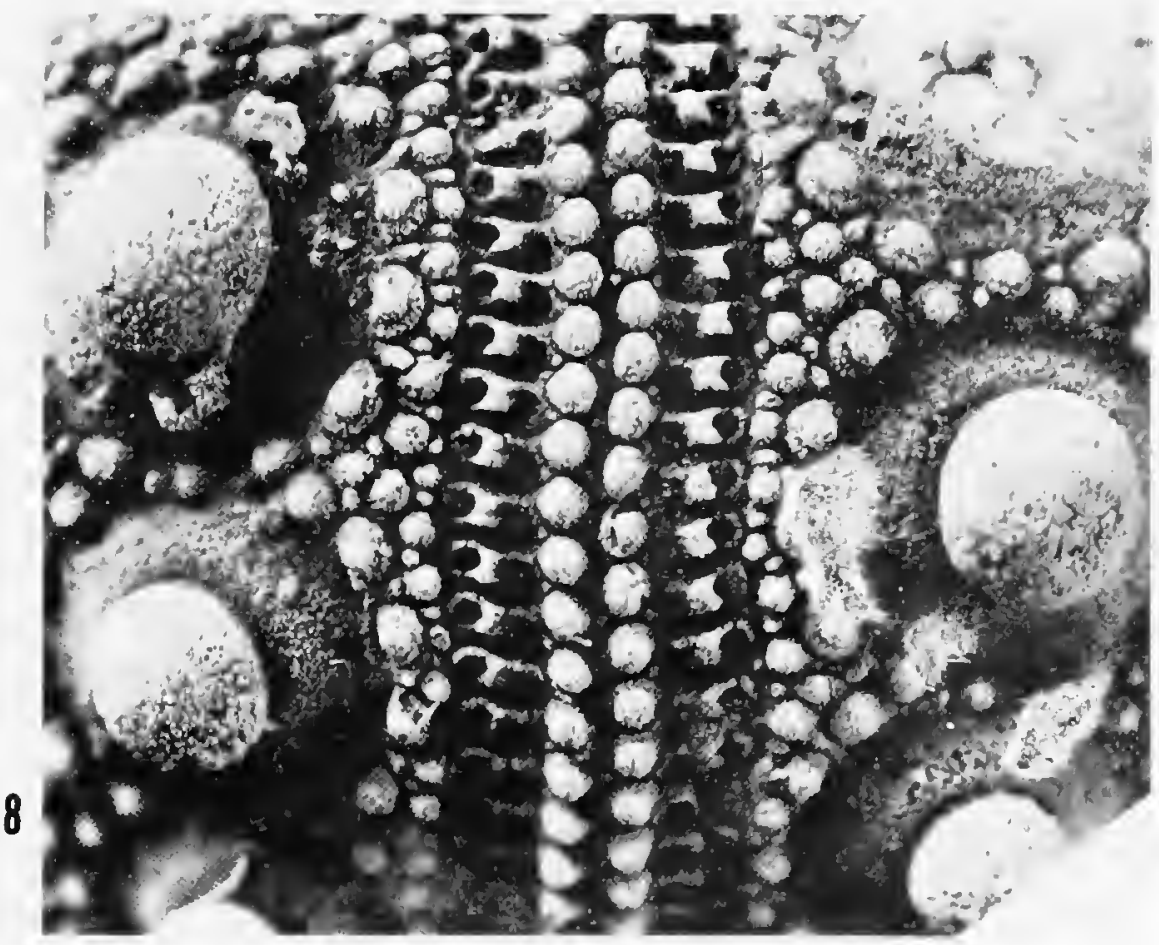




\section{PLATE 15}

\section{Levicidaris zardinia, new species}

1. Adoral view of ambulacrum of holotype, $\times 15$. (See Plate 14: figures 7,8 , for other views of this ambulacrum.)

2. Adapical view of 3143-S-Z, in MCA, $\times$ 7. Late Triassic, early Karnian, St. Cassian Beds, Alpe di Specie. Collector: Zardini.

3. View of edge of same specimen showing the vertical adradial suture, $\times 7$.

4. Interior view of 3144-S-Z, in MCA, $\times$ 7. Late Triassic, early Karnian, St. Cassian Beds, Alpe di Specie. Collector: Zardini.

5. Interior view showing the slight lantern supports at the ambulacra-interambulacra border, 3145-S-Z, in MCA, $\times 12$. Late Triassic, early Karnian, St. Cassian Beds, Alpe di Specie. Collector: Zardini.

\section{Megaporocidaris mariana, new species}

6, 7. Interior and edge views showing nearly vertical adradial suture, 3146-S-Z, in MCA, $\times$ 14. Late Triassic, early Karnian, St. Cassian Beds, Alpe di Specie. Collector: Zardini.

8. Interior view of $3147-\mathrm{S}-\mathrm{Z}$, in $\mathrm{MCA}, \times 12$. Same occurrence as the previous figures. Collector: Zardini. 

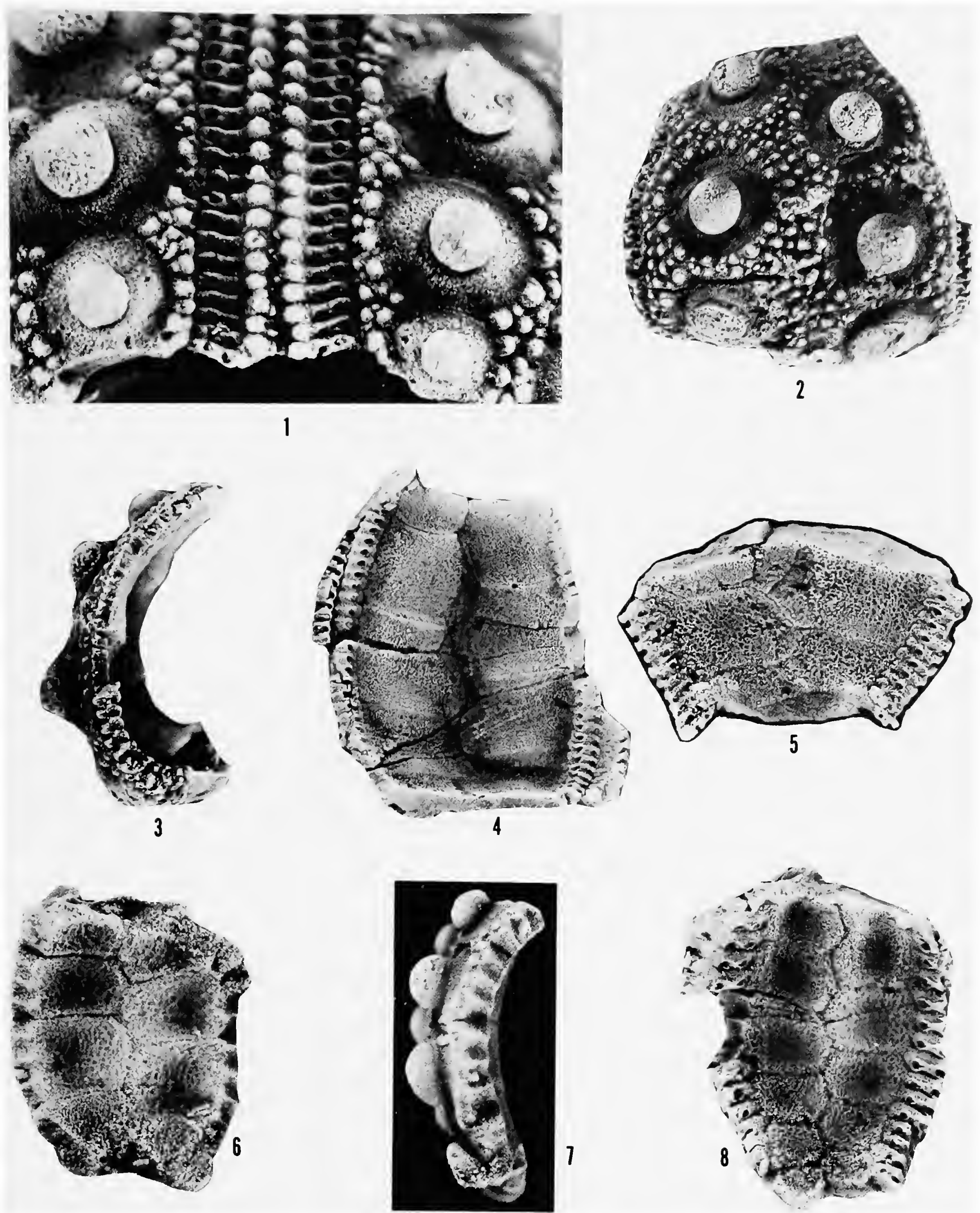


\section{PLATE 16}

Megaporocidaris mariana, new species

$1,2,3,4$. Adapical, side, adoral views of the holotype 2728-S-L, in MCA, $\times 8$. Collector: Lancedelli.

5. Midzone on an ambulacrum of the same specimen, $\times 19$.

$6,7,8,9$. Adapical, side, adoral views of paratype 176-S-Z, in MCA, $\times 6$. Collector: Zardini.

10. Side view of paratype 2729-S-L, in MCA, $\times 12$. Collector: Lancedelli.

All Late Triassic, early Karnian, St. Cassian Beds, Alpe di Specie. 


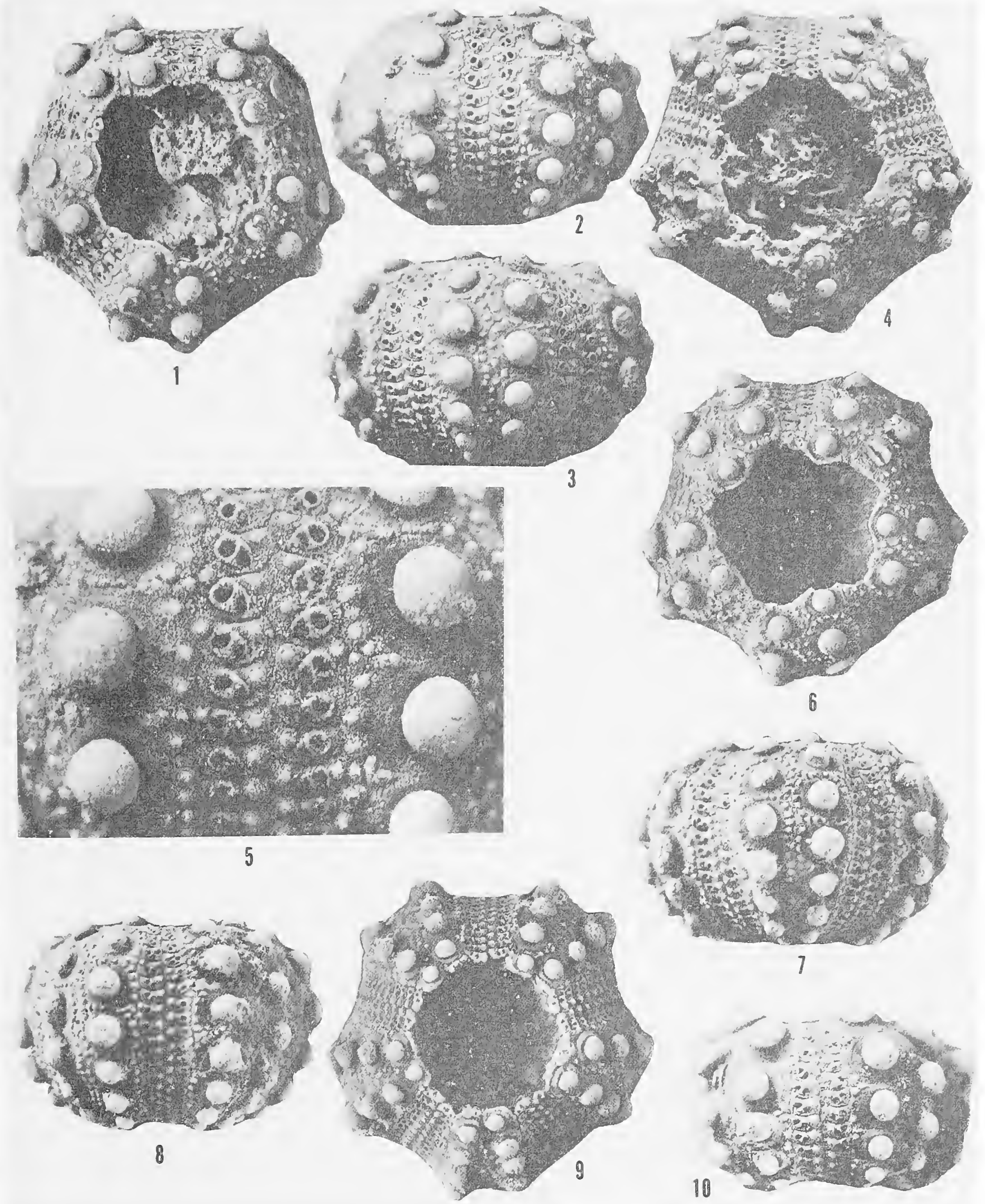




\section{PLATE 17}

\section{Tiarechinus princeps Neumayr}

1, 2, 3, 4. Adapical, adoral, and two side views of 193-S-Z, in MCA, $\times$ 12. Late Triassic, early Karnian, St. Cassian Beds, Alpe di Specie. Collector: Zardini.

5. Side view of $182-S T-Z$, in MCA, $\times 15$. Late Triassic, early Karnian, St. Cassian Beds, Boa Staolin. Collector: Zardini.

\section{Lysechinus incongruens Gregory}

6, 7, 8. Views of the holotype, E3935, in BMNH, $\times$ 7. Late Triassic, early Karnian, St. Cassian Beds, Italy. 

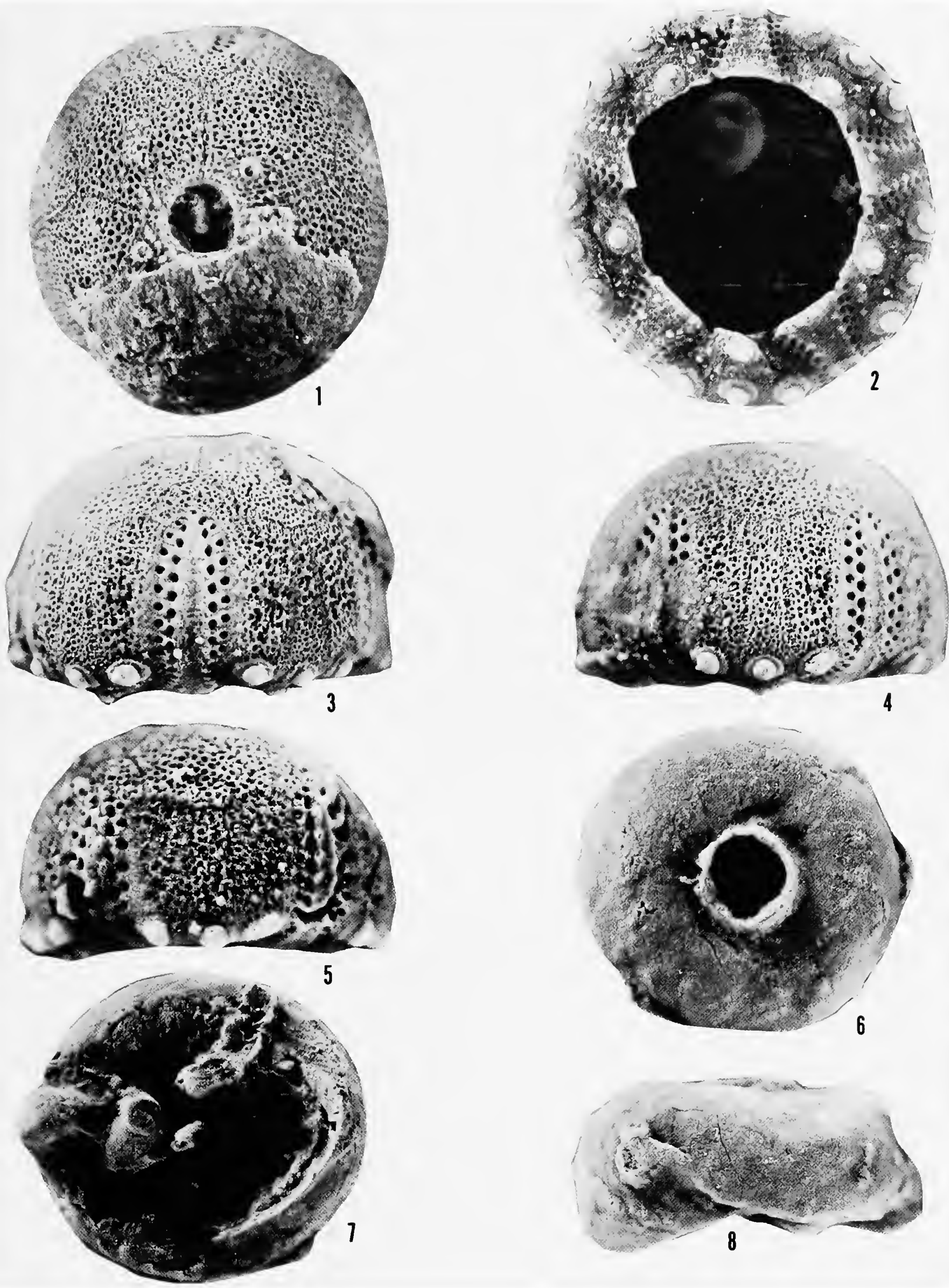


\section{PLATE 18}

\section{Triadocidaris species A}

1, 2. Fragments of interambulacra of $3148-S-Z$ and $3168-S-Z$, in MCA, $\times 4$. Late Triassic, early Karnian, St. Cassian Beds, Alpe di Specie. Collector: Zardini.

\section{Triadocidaris species $\mathbf{B}$}

3, 4. Exterior and interior views of 3149-S-Z, in MCA, $\times 11$. Late Triassic, early Karnian, St. Cassian Beds, Alpe di Specie. Collector: Zardini.

5. Exterior view of $3150-\mathrm{S}-\mathrm{Z}$, in MCA, $\times 10$. Same occurrence and collector as above.

Species with crenulate tubercles

6, 7. Species 1: exterior and interior view of specimen, 315l-C-Z, in MCA, $\times 7$. Note on the interior the denticulations and the depressions under the primary tubercles. Late Triassic, early Karnian, St. Cassian, Campo. Collector: Zardini.

8. Species 1: specimen 3152-C-Z, in MCA, $\times 5$. Same occurrence and collector as above. 

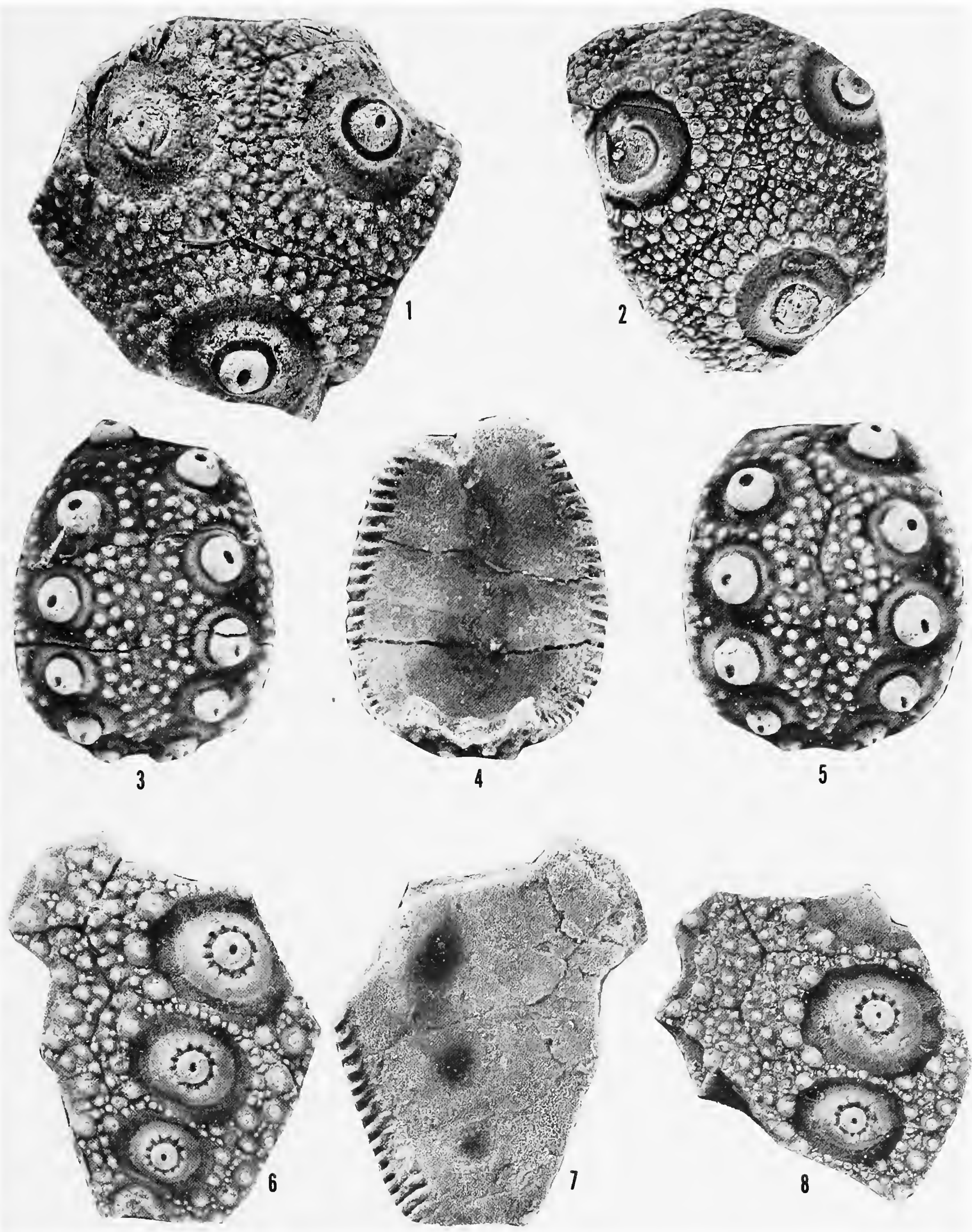


\title{
PLATE 19
}

\author{
Species with crenulate tubercles
}

1, 2. Species 1: exterior and interior views of 3153-C-Z, in MCA, $\times 5$. Late Triassic, early Karnian, St. Cassian Beds, Campo. Collector: Zardini.

3. Species 2: fragment showing most of interambulacrum, 3154-R-Z, in MCA, $\times 5$. Late Triassic, early Karnian, St. Cassian Beds, Rumerlo. Collector: Zardini.

4, 5. Species 3: exterior and interior views of the adoral portion of an interambulacrum, 3155-C-Z, in MCA, $\times$ 4. Late Triassic, early Karnian, St. Cassian Beds, Campo. Collector: Zardini.

\section{Mesodiadema? fragments}

6. Fragments of adoral portion of an interambulacrum, 3156-S-Z, in MCA, $\times 12$. Late Triassic, early Karnian, St. Cassian Beds, Alpe di Specie. Collector: Zardini.

7. Interior view of same specimen, showing a pophyses, $\times 12$.

8. Part of interambulacrum, 3157-S-Z, in MCA, $\times 12$. Late Triassic, early Karnian, St. Cassian Beds, Alpe di Specie. Collector: Zardini.

9. Adoral portion of interambulacrum, 3158-S-Z, in MCA, $\times 7$. Late Triassic, early Karnian, St. Cassian Beds, Alpe di Specie. Collector: Zardini. 

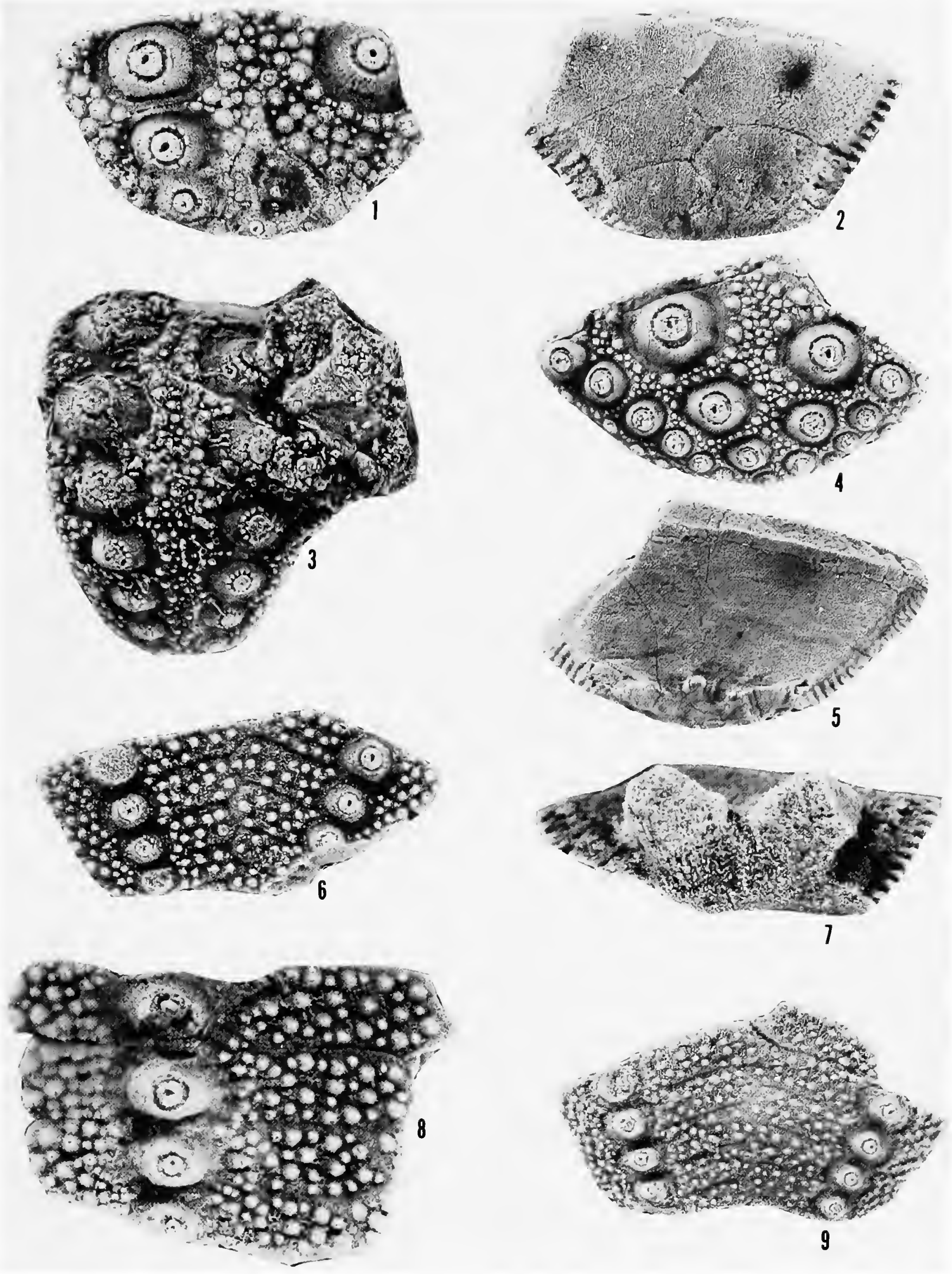


\section{PLATE 20}

\section{Mesodiadema? fragments}

1, 2. Exterior and interior view's of $3159-S-Z$, in $\mathbf{M C A}, \times 12$. Note apophyses on interior. Late Triassic, early Karnian, St. Cassian Beds, Alpe di Species. Collector: Zardini.

3, 4. Exterior and interior views of an isolated interambulacral plate, 3160-Mi-Z, in MCA, $\times 7$. Note denticulations on interior. Late Triassic, early Karnian, St. Cassian Beds, Milieres. Collector: Zardini.

5. Isolated interambulacral plate with a crenulated tubercle, 3161-Mi-Z, in MCA, $\times$ 15. Late Triassic, early Karnian, St. Cassian Beds, Milieres. Collector: Zardini.

$6,7,8,9$. Ambulacra of specimens 3162-C-Z, 3163-C-Z, 3164-C-Z, and 3165-C-Z, all in MCA, $\times 10, \times 8, \times 12, \times 7$. Note incipient development of compound plate with reduction in size of alternate plates. Late Triassic, early Karnian, St. Cassian Beds, Campo. Collector: Zardini.

10, 11. Edge and interior views of 3166-S-Z, in MCA, $\times 10$. Note auricles. Late Triassic, early Karnian, St. Cassian Beds, Alpe di Specie. Collector: Zardini.

12, 13. Exterior and interior of ambulacrum showing auricles, 3167-S-Z, in MCA, $\times 9$. Late Triassic, early Karnian, St. Cassian Beds, Alpe di Specie. Collector: Zardini. 

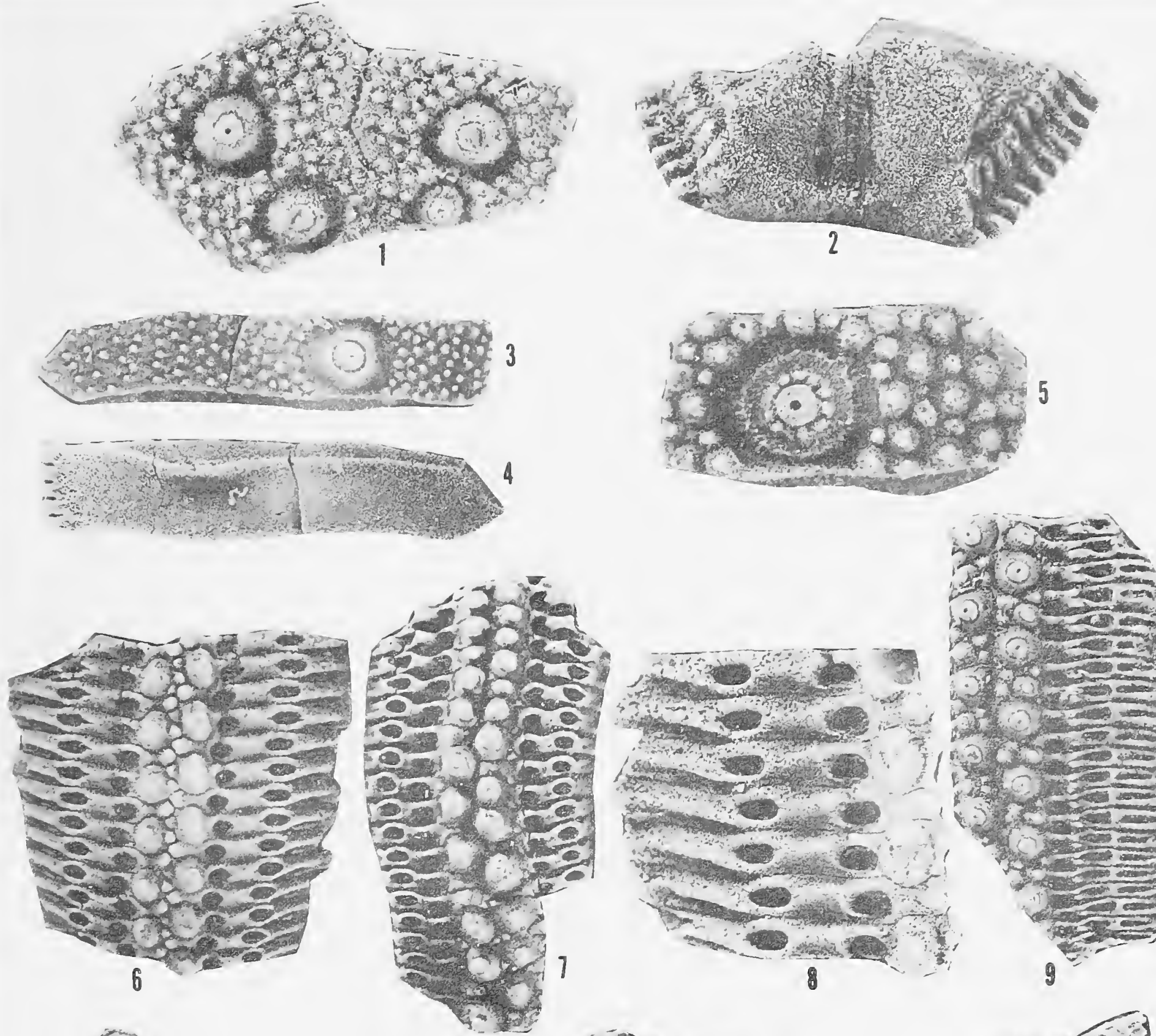

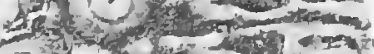

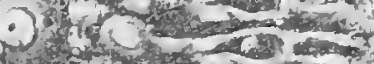
$4 \%$. 1.7. $-10-2$ $72 x+2=0$

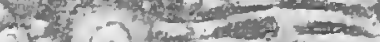

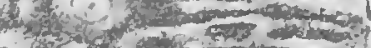

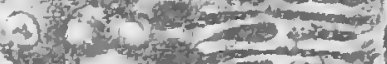
स.

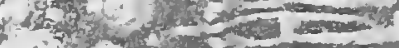

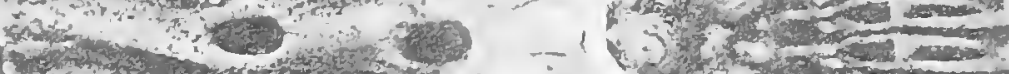
W

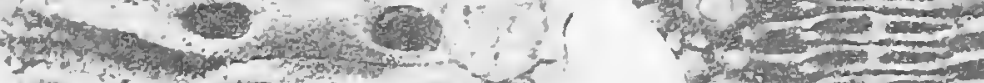

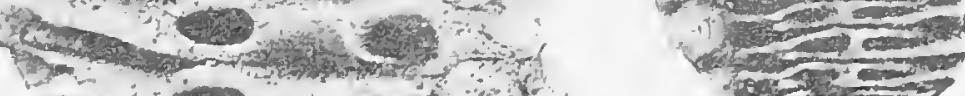
8 9
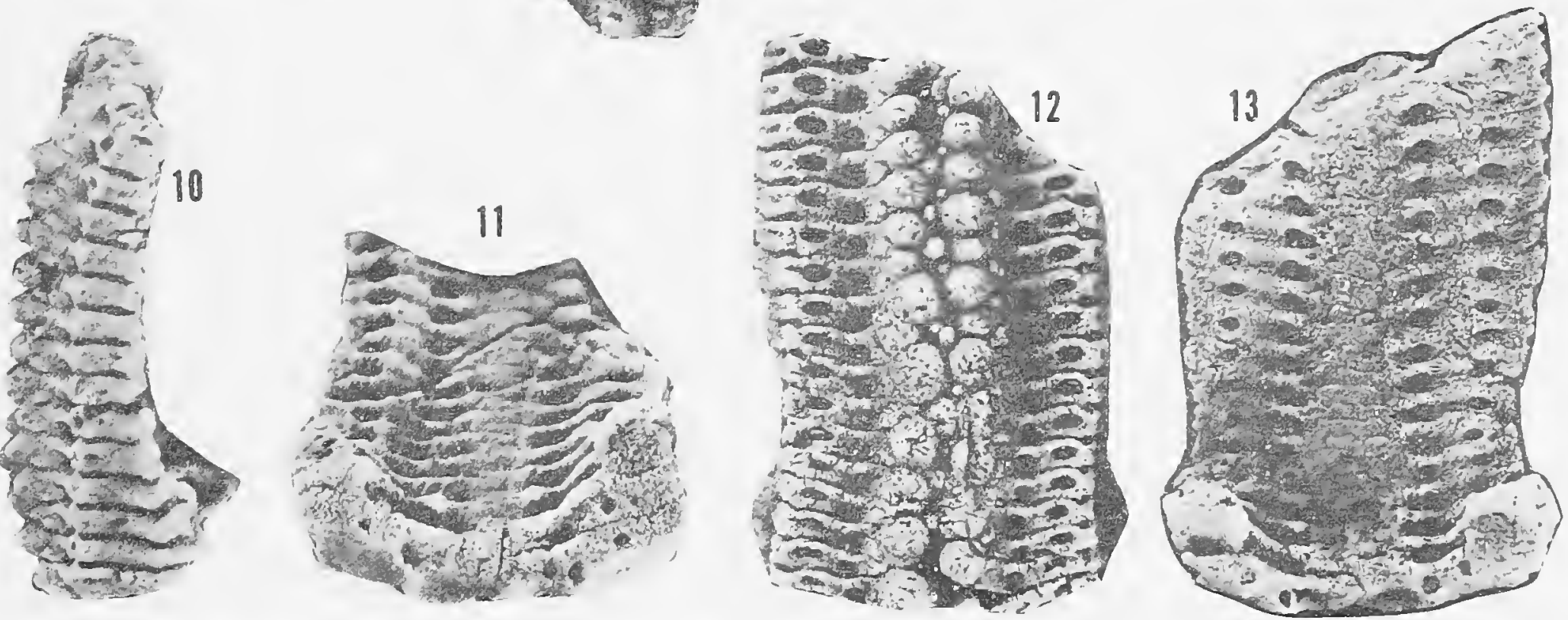


\section{PLATE 21}

\section{Dicyclocidaris denticulata Fell}

1. Latex pull of the holotype, EC 845 , in NZGS, $\times 4$. Note the longitudinal striations on the fragments of a spine indicating that the spines were not thorny. This specimen was figured in Fell (1950, fig. 1).

2. Latex pull of paratype, EC 846 , figured by Fell (1950, fig. 2 ), $\times 4$.

3. Latex pull of paratype, EC $848, \times 4$.

4. Latex pull showing the interior of an interambulacrum with denticulations along the adradial suture, and lantern supports, EC 847, figured by Fell (1950, fig. 3).

All the above specimens are from the Karnian at New Zealand Geological Survey locality GS 4560, Nelson, east side of Castle Hill, grid reference S20/427097.

\section{Hemipedina hudsoni, new species}

5, 6,7. Adapical, adoral, side view's of the holotype, E-76154, in BMNH, $\times$ 7.5. Late Triassic, Norian, Elphinstone Group, probably Sumra Formation, Wadi Milaha, Trucial Coast, Arabia.

8. View of ambulacrum adapical to ambitus of same specimen, $\times 10$.

9. View of inside edge of peristomial opening of same specimen showing auricles, $\times 16$.

\section{Quenstedt's Cidaris admelo not Braun}

10, 11. Specimens in IGP, $\times 4, \times 8$, figured by Quenstedt (1875, pl. 68: figs. 143-144). Aplocidaris helenae (de Regny)

12. Side view of the holotype in IGPB, $\times 12$. Late Triassic, Norian, of Montenegro. 

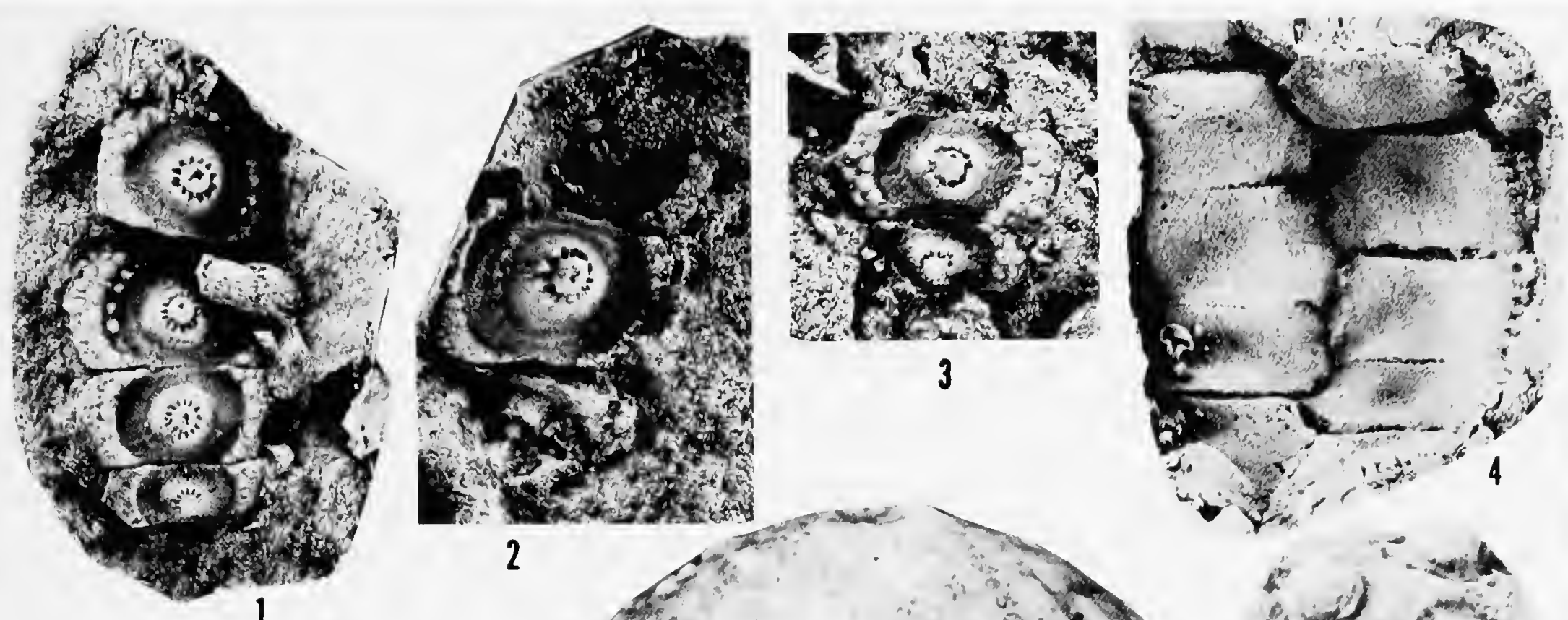
$-2-x-140459$
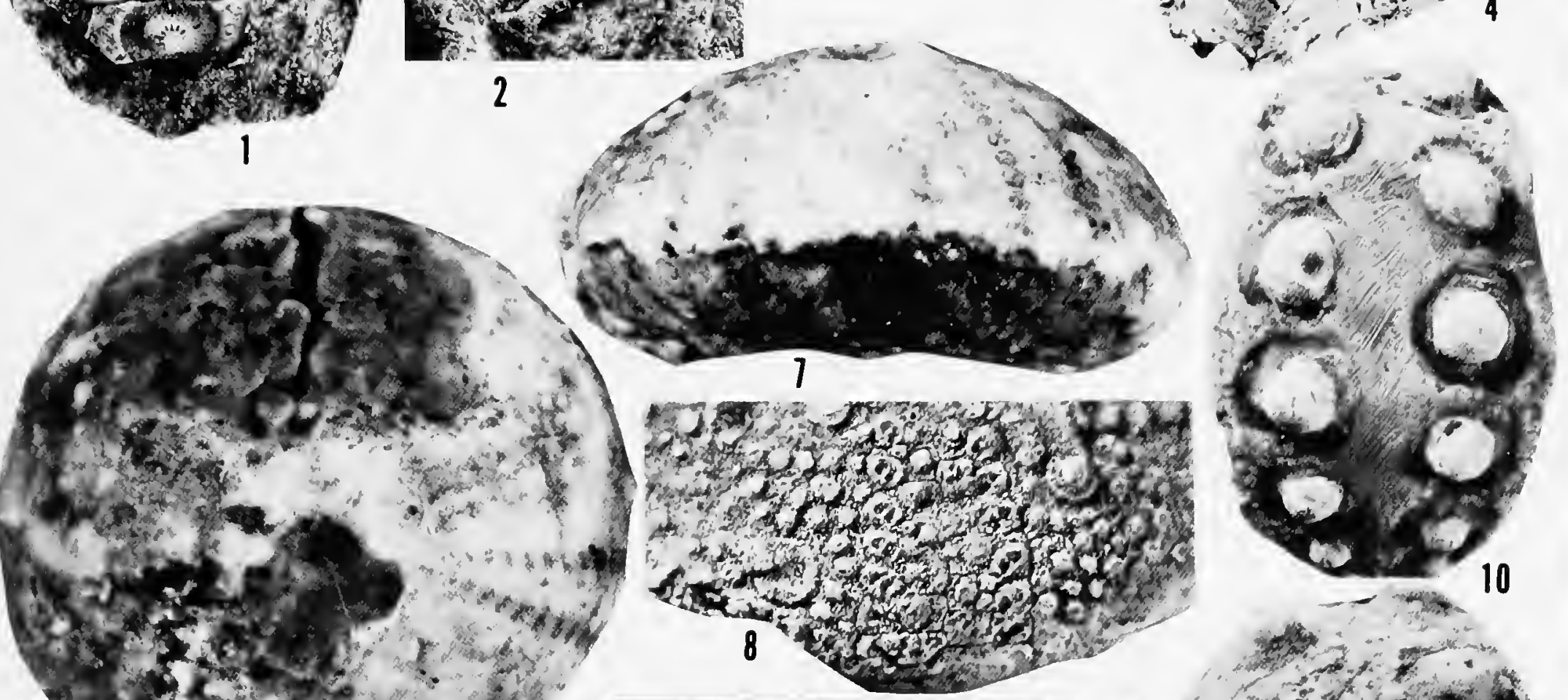

ton
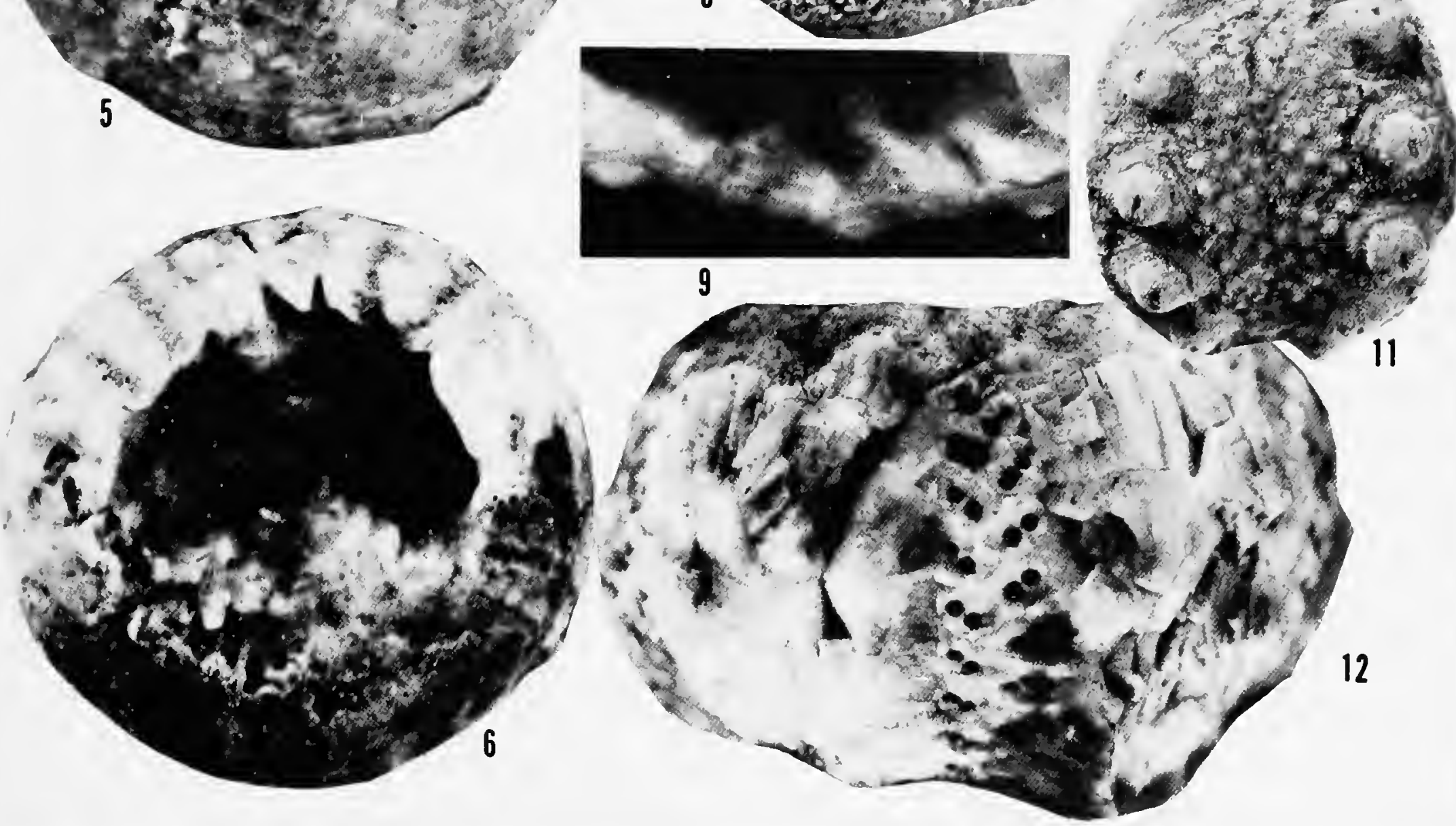
$4+25,25$

12 


\section{Index}

(Principal entries in italics)

Acrosalenia pustulata, 34

aculeata, Cidaris, 35

adametzi, Radiolus, 36

admeto. Cidaris, 16, 17, 18, 22, 36, 37

adrianae, Miocidaris, 38

aialensis, Cidaris, 35

alpina, Cidaris, 35

alternata, Cidaris, 35

alutensis, Radiolus, 36

ampezzana, Miocidaris, 26. 38

anatoliensis, Pronechinus, 2

Anaulocidaris, 35

faurai, 36

testudlo, 36

vinassai, 36

antipai, Radiolus, 36

Aplocidaris helenae, 36 (fig.), 84 (pl.)

austriaca, Cidaris, 35

Austrocidaris canaliculata, 15 (fig.)

avena, Cidaris, 35

Avicula contorta, 37

Balanocidaris, 35

barzaviae, Miocidaris, 38

biconica, Cidaris, 35

biformis, Cidaris, 35

boletus, Radiolus, 36

braunii, Cidaris, 35

buchii, Cidaris, 35

canaliculata, Austrocidaris, 15 (fig.)

cassiani, Miocidaris, 37,38

catenifera, Cidaris, 35

caudex, Cidaris, 35

caumonti, Paracidaris, 20

cf. T. venusta, Triadocidaris, 54 (pl.), 56 (pl.)

cfr. admeto, Cidaris, 16. 17.37

Cidaris

aculeata, 35

admeto, 16, 17, 18, 22, 36, 37, 84 (pl.)

aialensis, 35

alpina, 35

alternata, 35

austriaca, 35

avena, 35

biconica, 35

biformis, 35

braunii, 35

buchii, 35

catenifera, 35 caudex, 35

cfr. admeto, 16, 17

cingulata, 35

coralliophila, 35

cornaliae, 37

costalarensis, 35

costata, 35

costeanensis, 35

crenulata, 37

curionii, 37

decorata, 35

decoratissima, 35

desori, 36

dorsata, 35

ecki, 35

lorminensis, 35

fumagalli, 37

fustis, 35

gerana, 11, 12, 56 (pl.)

gilletae, 35

glabra, 35

hausmanni, 35

helenac, 36

klipsteini, 37

lanceata, 35.

lancedelli, 16

lanceolata, 37

leonareli, 27, 37

liagora, 37

linearis, 35

longispina, 37

magna, 37

milierensis, 35

montanaro, 20

ombonii, 37

ovata, 35

pentagona, 13

perplexa, 35

petersii, 35

plana, 35

pyramidalis, 35

quadrialata, 35

quadriserrata, 35

regnyi, 35

regularis, 15

remifera, 35

reticulata, 35

rinbianchi, 18, 66 (pl.)

rocmeri, 35,36

schwageri, 35

scrobiculata, 35 seelandica, 35

semicostata, 35

shastensis, 37

similis, 35

spinachristi, 35

spongiosa, 35

staulinensis, 37

stipes, 35

stoppanii. 35

subcoronata, 37

subpentagona, 13, 15, 50 (pl.)

subsimilis, 8

subspinulosa, 35

suessii, 10

sulcata, 35

tenuicostata, 35

letraedrica, 35

toucasi, 32

transi'ersa, 35

trapezoidalis, 36

trigona, 36

triserrata, 36

I yrolensis, 36

undulatus, 36

valparolac, 36

venusta, 11

verticillata, 35,36

waechteri, 36

wissmanni, 36

zardini, 36

cingulata, Cidaris, 35

complanatus, Radiolus, 36

contorta, Avicula, 37

coralliophila, Cidaris, 35

cornaliae, Cidaris, 37

coronensis, Triadocidaris, 38

cortinensis, Miocidaris, 38

costalarensis, Cidaris, 35

costata, Cidaris, 35

costeanensis, Cidaris, 35

crenulata, Cidaris, 37

culter, Radiolus, 36

curionii, Cidaris, 37

curmaturi, Miocidaris, 38

decorata, Cidaris, 35

decoratissima, Cidaris, 35

(lenticulata, Dicyclocidaris, 4

desori, Cidaris, 36

Diaclemopsis, 4

Hypodiadema, 32, 33 
Diadema microporum, 38

Diademopsis, 29, 31, 32, 33

desori, 4, 33 (fig.), 37

heeri, 31,38

michelini, 31

micropora, 31

parvituberculata, 38

Dicyclocidaris, 28

denticulata, 4, 28, 84 (pl.)

dorsata, Cidaris, 35

ccki, Cidaris, 35

Eocidaris laubei, 37

Eodiadema regulare, 15

etheridgei, Hemipedina, 31

faurai, Anaulocidaris, 36

festuca, Radiolus, 36

forminensis, Cidaris, 35

fumagalli, Cidaris, 37

fustis, Cidaris, 35

fusus, Radiolus, 36

gerana, Cidaris, 11, 12

Microcidaris, Il

Mikrocidaris, II

giauensis, Triadocidaris, 7, 12, 13, 25, 26, 58 (pl.)

gilletae, Cidaris, 35

glabra, Cidaris, 35

gracilis, Hemicidaris, 36

hausmanni, Cidaris, 35

heeri, Diademopsis, 31, 38

helenae, Aplocidaris, 36 (fig.)

Cidaris, 36

Hemicidaris

gracilis, 36

luciensis, 34

obliquelineata, 36

regularis, 15

Hemipedina, 29, 30, 31, 37

etheridgei, 31

hudsoni, 2, 4, 29, 30, 31 (fig.), 84 (pl.)

incipiens, 4, 29, 30 (fig.)

jefferiesi, 31

michelini, 38

herbichi, Radiolus, 36

hescheleri, Miocidaris (Serpianotiaris), 6 Serpianotiaris, 6, 7, 46 (pl.)

honorinae, Merocidaris, 21

hudsoni, Hemipedina, 4, 29, 30, 31 (fig.)

Hypodiadema

desori, 32, 33

regularis, 15

immunita, Triadocidaris, 28,29 (fig.)

incipiens, Hemipedina, 4, 29, 30 (fig.)

incongruens, Lysechinus, 24, 76 (pl.) jeanneti, Paracidaris, 4, 32 (fig.)

jefferiesi, Hemipedina, 31

klipsteini, Cidaris, 37

lanceata, Cidaris, 35

lancedelli, Cidaris, 16

Zardinechinus, $4,7,16,17,18,37,60$ (pl.), 64 (pl.), 66 (pl.)

linceolata, Cidaris, 37

latum, Mesodiadema, 27

laubei, Eocidaris, 37

Lenticidaris, 4,6

utahensis, 3, 6, 7, 44 (pl.)

leonardi, Cidaris, 27, 37

Leurocidaris, 20

montanaro, 4, 7, 20, 26, 66 (pl.), 68 (pl.)

Levicidaris, 21,23

zardinia, $4,7,21,23,37,70(\mathrm{pl}),$. (pl.)

liagora, Cidaris, 37

Triadocidaris, 37

linearis, Cidaris, 35

lincola, Radiolus, 36

longispina, Cidaris, 37

luciensis, Hemicidaris, 34

lungauensis, Triadocidaris, 38

Lysechinus, 24

incongruens, 24,76 (pl.)

magna, Cidaris, 37

margaritatum, Mesodiadema, 27, 37

mariana, Megaporocidaris, 4, 7, 15, 22, 23, 72 (pl.), 74 (pl.)

Megaporocidaris, 22, 23, 36

mariana, 4, 7, 15, 22, 23, 72 (pl.), 74 (pl.)

Merocidaris, 21

honorinae, 21

Mesodiadema, 27, 37, 80 (pl.), 82 (pl.)

latum, 27, 37

margaritatum, 27, 37

michelini, Diademopsis, 31 Hemipedina, 38

Microcidaris

gerana, I I

pentagona, 13

venusta, 11

micropora, Diademopsis, 31

microporum, Diadema, 38

Mikrocidaris, I1, 13, 15, 23, 36

gerana, 11

pentagona, $4,7,11,13,14$ (fig.), 15

(fig.), 46 (pl.), 48 (pl.), 50 (pl.) ...

subpentagona, 13, 15, 23

venusta, 11

milierensis, Cidaris, 35

Miocidaris, 3, 6, 7

adrianae, 38

ampezzana, 26, 38 barzaviae, 38

cassiani, 37,38

cortinensis, 38

curmaturi, 38

hescheleri, 6

pakistanensis, 3, 6, 44 (pl.)

planus, 38

timorensis, 38

verrucosus, 38

montanaro, Cidaris, 20

Leurocidaris, 4, 7, 20, 26, 66 (pl.), 68 (pl.)

multiceps, Polycidaris, 16

obliquelineata, Hemicidaris, 36

ombonii, Cidaris, 37

ovata, Cidaris, 35

pakistanensis, Miocidaris, 3, 6, 44 (pl.)

Paracidaris, 20, 32

caumonti, 20

jeanneti, 4, 32 (fig.)

toucasi, 4, 32 (fig.)

parvituberculata, Diademopsis, 38

Paurocidaris, 18

rinbianchi, 4, 7, 18, 19 (fig.), 26, 64 (pl.), 66 (pl.)

penna, Radiolus, 36

pentagona, Cidaris, 13

Microcidaris, 13

Mikrocidaris, 4, 7, 11, 13, 14 (fig.), I5

(fig.), 46 (pl.), 48 (pl.), 50 (pl.)

perplexa, Cidaris, 35

persimilis, Triadocidaris, 4,28 (fig.)

petersii, Cidaris, 35

plana, Cidaris, 35

planorbis, Psiloceras, 38

planus, Miocidaris, 38

Plegiocidaris, 16,18

senex, 36

Polycidaris, 15, 16, 18

multiceps, 16

regularis, $4,7,15,26,58$ (pl.)

praeternobilis, Triadocidaris, 38

princeps, Tiarechinus, 4, 7, 24, 25 (fig.), 76 (pl.)

Procidaris, 18

Pronechinus anatoliensis, 2

Pseudodiadema, 33

silbinense, 5, 33, 34 (fig.)

veronensis, 38

Psiloceras planorbis, 38

pustulata, Acrosalenia, 34

pyramidalis, Cidaris, 35

quadrialata, Cidaris, 35

quadriserrata, Cidaris, 35

racadaui, Radiolus, $\mathbf{3 6}$ 


\section{Radiolus}

adametzi, 36

alutensis, 36

antipai, 36

boletus, 36

complanatus, 36

culter, 36

festuca, 36

fusus, 36

herbichi, 36

lineola, 36

penna, 36

racadaui, 36

raiblianus, 36

rostratus, 36

segmentatus, 36

subnodosus, 37

raiblianus, Radiolus, 36

regnyi, Cidaris, 35

regulare, Eodiadema, 15

regularis, Cidaris, 15

Hemicidaris, 15

Hypodiadema, 15

Polycidaris, 4, 7, 15, 26, 58 (pl.)

remifera, Cidaris, 35

reticulata, Cidaris, 35

Rhabdocidaris, admeto, 36

rinbianchi, Cidaris, 18, 66 (pl.)

Paurocidaris, 4, 7, 18, 19 (fig.), 26, 64 (pl.), 66 (pl.)

roemeri, Cidaris, 35,36

rostratus, Radiolus, 36

schwageri, Cidaris, 35

scrobiculata, Cidaris, 35

seelandica, Cidaris, 35

segmentatus, Radiolus, 36

semicostata, Cidaris, 35

senex, Plegiocidaris, 36
Serpianotiaris, 6

hescheleri, 3, 6, 7, 46 (pl.)

shastensis, Cidaris, 37

silbinense, Pseudodiadema, 5, 33, 34 (fig.)

similis, Cidaris, 35

spinachristi, Cidaris, 35

spongiosa, Cidaris, 35

staulinensis, Cidaris, 37

stipes, Cidaris, 35

stoppanii, Cidaris, 35

subcoronata, Cidaris, 37

subnobilis, Triadocidaris, 38

subnodosus, Radiolus, 37

subpentagona, Cidaris, 13, 15, 50 (pl.)

Mikrocidaris, 13, 15, 23

subsimilis, Cidaris, 8

Triadocidaris, 4, 7, 8, 9, (fig.), 11, 12, $13,25,26,50$ (pl.), 52 (pl.)

subspinulosa, Cidaris, 35

suessii, Cidaris, 10

suessi(i), Triadocidaris, 4, 7, 10 (table), $12,26,52$ (pl.)

sulcata, Cidaris, 35

tenuicostata, Cidaris, 35

testudo, Anaulocidaris, 36

tetraedrica, Cidaris, 35

Tiarechinus, 24

princeps, 4, 7, 24, 25 (fig.), 76 (pl.)

timorensis, Miocidaris, 38

toucasi, Cidaris, 32

Paracidaris, 4, 32 (fig.)

transversa, Cidaris, 35

trapezoidalis, Cidaris, 36

Triadocidaris, 4, 8, 10, 11, 12, 13, 17, 25, $27,28,29,37$

cf. T. venusta, 54 (pl.), 56 (pl.)

coronensis, 38

giauensis, 4, 7, 12, 13, 25, 26, 58 (pl.) immunita, 4, 28, 29 (fig.)

liagora, 37

lungauensis, 38

persimilis, 4,28 (fig.)

praeternobilis, 38

sp. A, 25, 78 (pl.)

sp. B, 25, 78 (pl.)

subnobilis, 38

subsimilis, $4,7,8,9$ (fig.), $11,12,13$, $25,26,50$ (pl.), 52 (pl.)

suessi(i), 4, 7, 10, (table), 12, 26, 52 (pl.)

venusta, $4,7,11,12$ (table), 18, 26, 52

(pl.)

trigona, Cidaris, 36

triserrata, Cidaris, 36

tyrolensis, Cidaris, 36

undulatus, Cidaris, 36

utahensis, Lenticidaris, 3, 6, 7, 44 (pl.)

valparolae, Cidaris, 36

venusta, Cidaris, 11

Microcidaris, 11

Mikrocidaris, 11

Triadocidaris, 4, 7, 11, 12 (table), 18, 26, 52 (pl.)

veronensis, Pseudodiadema, 38

verrucosus, Miocidaris, 38

verticillata, Cidaris, 35,36

vinassai, Anaulocidaris, 36

waechteri, Cidaris, 36

wissmanni, Cidaris, 36

Zardinechinus, 16,18

lancedelli, 4, 7, 16, 17, 18, 37, 60 (pl.), 62 (pl.), 64 (pl.)

zardini, Cidaris, 36

zardinia, Levicardis, $4,7,21,23,37,70$ (pl.), 72 (pl.) 


\section{REQUIREMENTS FOR SMITHSONIAN SERIES PUBLICATION}

Manuscripts intended for series publication receive substantive review within their originating Smithsonian museums or offices and are submitted to the Smithsonian Institution Press with approval of the appropriate museum authority on Form SI-36. Requests for special treatment-use of color, foldouts, casebound covers, etc.-require, on the same form, the added approval of designated committees or museum directors.

Review of manuscripts and art by the Press for requirements of series format and style, completeness and clarity of copy, and arrangement of all material, as outlined below, will govern, within the judgment of the Press, acceptance or rejection of the manuscripts and art.

Copy must be typewritten, double-spaced, on one side of standard white bond paper, with 11/4" margins, submitted as ribbon copy (not carbon or xerox), in loose sheets (not stapled or bound), and accompanied by original art. Minimum acceptable length is 30 pages.

Front matter (preceding the text) should include: title page with only title and author and no other information, abstract page with author/title/series/etc., following the establish. ed format, table of contents with indents reflecting the heads and structure of the paper.

First page of text should carry the title and author at the top of the page and an unnum. bered footnote at the bottom consisting of author's name and professional mailing address.

Center heads of whatever level should be typed with initial caps of major words, with extra space above and below the head, but with no other preparation (such as all caps or underline). Run-in paragraph heads should use period/dashes or colons as necessary.

Tabulations within text (lists of data, often in parallel columns) can be typed on the text page where they occur, but they should not contain rules or formal, numbered table heads.

Formal tables (numbered, with table heads, boxheads, stubs, rules) should be submitted as camera copy, but the author must contact the series section of the Press for editorial attention and preparation assistance before final typing of this matter.

Taxonomic keys in natural history papers should use the alined-couplet form in the zoology and paleobiology series and the multi-level indent form in the botany series. If cross-referencing is required between key and text, do not include page references within the key, but number the keyed-out taxa with their corresponding heads in the text.

Synonymy in the zoology and paleobiology series must use the short form (taxon, author, year:page), with a full reference at the end of the paper under "Literature Cited." For the botany series, the long form (taxon, author, abbreviated journal or book title، volume, page, year, with no reference in the "Literature Cited") is optional.

Footnotes, when few in number, whether annotative or bibliographic, should be typed at the bottom of the text page on which the reference occurs. Extensive notes must appear at the end of the text in a notes section. If bibliographic footnotes are required, use the short form (author/brief title/page) with the full reference in the bibliography.

Text-reference system (author/year/page within the text, with the full reference in a "Literature Cited" at the end of the text) must be used in place of bibliographic footnotes in all scientific series and is strongly recommended in the history and technology series: "(Jones, 1910:122)" or ". . . Jones (1910:122)."

Bibliography, depending upon use, is termed "References," "Selected References," or "Literature Cited." Spell out book, journal, and article titles, using initial caps in all major words. For capitalization of titles in foreign languages, follow the national practice of each language. Underline (for italics) book and journal titles. Use the colon-parentheses system for volume/number/page citations: "10(2):5-9." For alinement and arrangement of elements, follow the format of the series for which the manuscript is intended.

Legends for illustrations must not be attached to the art nor included within the text but must be submitted at the end of the manuscript-with as many legends typed, double. spaced, to a page as convenient.

Illustrations must not be included with in the manuscript but must be submitted sepa rately as original art (not copies). All illustrations (photographs, line drawings, maps, etc.) can be intermixed throughout the printed text. They should be termed Figures and should be numbered consecutively. If several "figures" are treated as components of a single larger figure, they should be designated by lowercase italic letters (underlined in copy) on the illustration, in the legend, and in text references: "Figure 9b." If illustrations are intended to be printed separately on coated stock following the text, they should be termed Plates and any components should be lettered as in figures: "Plate 9b." Keys to any symbols within an illustration should appear on the art and not in the legend.

A few points of style: (1) Do not use periods after such abbreviations as " $\mathrm{mm}$, $\mathrm{ft}$, yds, USNM, NNE, AM, BC." (2) Use hyphens in spelled-out fractions: "two-thirds." (3) Spell out numbers "one" through "nine" in expository text, but use numerals in all other cases if possible. (4) Use the metric system of measurement, where possible, instead of the English system. (5) Use the decimal system, where possible, in place of fractions. (6) Use day/month/year sequence for dates: "9 April 1976." (7) For months in tabular listings or data sections, use three-letter abbreviations with no periods: "Jan, Mar, Jun," etc.

Arrange and paginate sequentially EVERY sheet of manuscript--including ALL front matter and ALL legends, etc., at the back of the text-in the following order: (1) title page, (2) abstract, (3) table of contents, (4) foreword and/or preface, (5) text, (6) appendixes, (7) notes, (8) glossary, (9) bibliography, (10) index, (11) legends. 


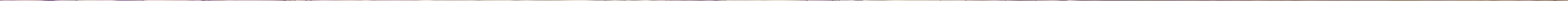

